This is the final peer-reviewed accepted manuscript of

MOLLEMA, PAULINE NELLA; ANTONELLINI, MARCO: Water and (bio)chemical cycling in gravel pit lakes: A review and outlook. EARTH-SCIENCE REVIEWS 159. ISSN 0012-8252

DOI: 10.1016/j.earscirev.2016.05.006

The final published version is available online at:

http://www.sciencedirect.com/science/journal/00128252

Rights / License:The terms and conditions for the reuse of this version of the manuscript are specified in the publishing policy. For all terms of use and more information see the publisher's website. 


\title{
Water and (bio)chemical cycling in gravel pit lakes: A review and outlook
}

\author{
Pauline N. Mollema ${ }^{\mathrm{a}, \mathrm{b}, *}$, Marco Antonellini ${ }^{\mathrm{a}}$ \\ a University of Bologna, Department of Biological, Geological and Environmental Sciences, Ravenna Campus, Via San Alberto 163,48123 Ravenna, Italy \\ b Technical University Delft, Department of Geosciences \&' Engineering, The Netherlands
}

\section{A R T I C L E I N F O}

Keywords:

Gravel pit lakes

Hydrology

Hydrochemistry

Ecological functioning

Land use change Climate

change Groundwater

Surface water

Lake sediments

Evaporation

Redox reactions

Dissolution-

precipitation Nutrients

Metals

Alkalinity

Fluvial setting

Coastal setting

Eutrophication

Habitat

Phytoplankton

\begin{abstract}
A B S T R A C T
The world produces $1.7 \times 10^{8}$ metric tons of gravel and sand per year (USGS, 2015) creating many gravel pit lakes that change the morphology and drainage pattern of catchments. Gravel pit lakes abruptly intersect the geologic layering creating an environment where surface and groundwater will interact and where elaborate food webs can develop. Here we preview previous work on gravel pit lakes and compiled a comprehensive hydrochemical database to compare the chemistry of gravel pit lake water with other types of surface and groundwater. Water budget calculations confirm that gravel pit lakes cause freshwater loss in temperate and Mediterranean climates where surface water evaporation is larger than the actual evapotranspiration of vegetated land that was replaced by the gravel pit lakes. Groundwater fed gravel pit lakes where evaporated water is replaced by groundwater are especially sensitive to climate change.

The gravel pit lakes included in this review have a relatively low acidity and high alkalinity most likely caused by weathering and leaching of carbonates in the catchment. The inflow of groundwater is a key process in gravel pit lakes with important consequences. The creation or presence of the gravel pit lakes may induce fluctuation of the up stream water table which enhances groundwater flow and redox reactions in the soil. Groundwater rich in dissolved elements typically meets more alkaline water in gravel pit lakes enhancing the precipitation of metal oxides, calcite and other composite minerals including phosphorus (P), calcium (Ca) and carbon (C). Gravel pit lakes provide many different ecological habitats increasing the biodiversity in typically an agricultural or urban setting. Plant and animal species observed in gravel pit lakes consists of phytoplankton, zooplankton, micro plankton, macrophytes, fish and birds similar to natural lakes but the fact that gravel pit lakes may be only groundwater fed, or instead in open contact with rivers causes large variations between the ecosystem of different lakes. Plants and animal species take part in the chemical cycling of gravel pit lakes by, among others, uptake of atmospheric carbon dioxide $\left(\mathrm{CO}_{2}\right)$ and nitrogen $\left(\mathrm{N}_{2}\right)$, of dissolved compounds including bicarbonate $\left(\mathrm{HCO}_{3}\right)$, iron $(\mathrm{Fe})$ and manganese $(\mathrm{Mn})$; of elements including phosphate $(\mathrm{P})$ and Fe from lake sediments, and carbon mineral ization and burial. Gravel pit lakes may contribute to denitrification of groundwater as $\mathrm{N}$ is consumed by plankton, but they may also enhance the mobilization of soil bound compounds like potentially toxic (trace) metals released from aquifer sediments. The creation of gravel pit lakes provides more available sites for carbon burial but once de posited on the lake bottom, metals and other elements may be released again due to redox cycling, influenced by climatic or land use change. Gravel pit lakes are water bodies of recent formation and so far only a few different set tings have been studied in detail compared to other types of natural and man made lakes. From this review it is ev ident that gravel pit lakes are hydrochemically most similar to so called 'marl lakes' or 'nutrient rich' lakes. Key areas for further research include the study of gravel pit lakes in other settings to better separate the similarities and dif ferences between natural and gravel pit lakes. Also the feedback mechanisms between change in land use and cli mate, ground and lake water chemistry ecological functioning and use of the gravel pit lakes need to be addressed.
\end{abstract}

\section{Contents}

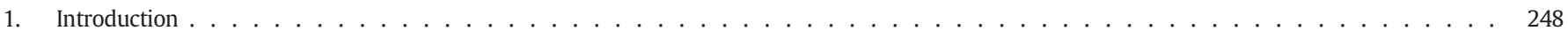

2. Geological settings . . . . . . . . . . . . . . . . . . . . . . . . . . . . . . . . . . . 249

2.1. Gravel pit lakes versus natural lakes . . . . . . . . . . . . . . . . . . . . . . . . . . . . . . . . . . . . 249

2.2. Depositional environment . . . . . . . . . . . . . . . . . . . . . . . . . . . . . . . . . . . . . . . 249

* Corresponding author at: University of Bologna, Department of Biological, Geological and Environmental Sciences, Ravenna Campus, Via San Alberto 163, 48123 Ravenna, Italy. E-mail addresses: pmollema@gmail.com (P.N. Mollema), m.antonellini@unibo.it (M. Antonellini). 


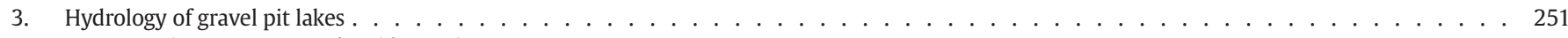

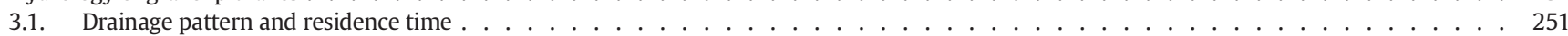

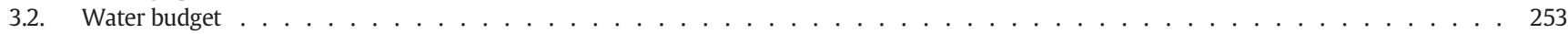

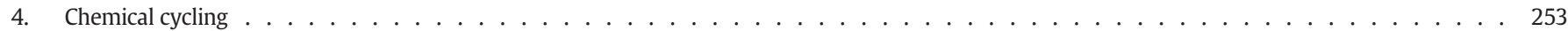

4.1. Chemistry of gravel pit lake water versus other types of surface and ground water . . . . . . . . . . . . . . . . . 253

4.2. Nutrient cycling . . . . . . . . . . . . . . . . . . . . . . . . . . . . . . . . . . . . 253

4.3. Carbon and Ca cycling. . . . . . . . . . . . . . . . . . . . . . . . . . . . . . . . 254

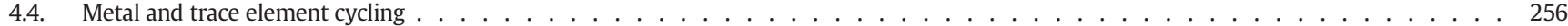

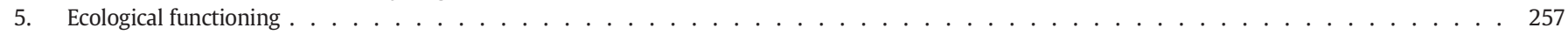

6. Effects of climate change on hydrological aspects of gravel pit lakes . . . . . . . . . . . . . . . . . . . . . . . . . 259

6.1. Changes in $\mathrm{E}^{2}$ and $\mathrm{ET}_{\mathrm{a}} \ldots \ldots \ldots \ldots \ldots \ldots$

6.2. Hydrological and meteorological extremes . . . . . . . . . . . . . . . . . . . . . . . . . . . . 261

6.3. Lake and groundwater temperature . . . . . . . . . . . . . . . . . . . . . . . . . . . . . . . . 261

7. Implications of land use and climate change on chemical and ecological aspects of gravel pit lakes . . . . . . . . . . . . . . . . . 262

7.1. Nutrient cycling under climate and land use change. . . . . . . . . . . . . . . . . . . . . . . . . . . 262

7.2. Carbon and Ca cycling under climate and land use change . . . . . . . . . . . . . . . . . . . . . . . . . 263

7.3. Metal and trace element cycling under climate and land use change . . . . . . . . . . . . . . . . . . . . . . . . . . 263

7.4. Ecological functioning under climate and land use change . . . . . . . . . . . . . . . . . . . . . . . 263

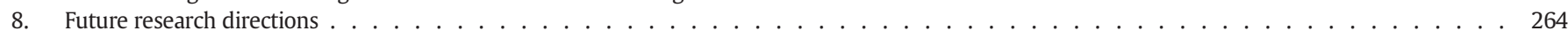

8.1. Water budget measurements . . . . . . . . . . . . . . . . . . . . . . . . 264

8.2. Hydrochemistry, ecological functioning and biomanipulation . . . . . . . . . . . . . . . . . . . . . . . 264

9. Summary and conclusions . . . . . . . . . . . . . . . . . . . . . . . . . . . . . . . 265

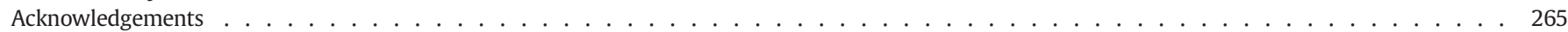

Appendix A. List of symbols . . . . . . . . . . . . . . . . . . . . . . . . . . . . . . . . . . . . . . . . . . . . . 266

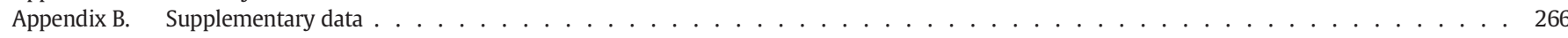

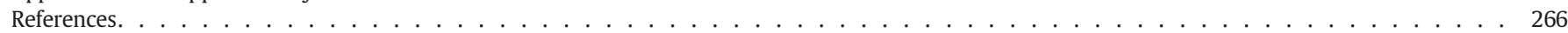

\section{Introduction}

Our modern society uses an enormous amount of sand and gravel to construct buildings, highways and anything made of concrete. According to the USGS (2015a, b) the world produces a total of $1.65 \times 10^{8}$ metric tons tons of sand and gravel per year (Table 1 ) with the USA, Italy, and Germa ny as the three main producers. Gravel is produced from natural gravel deposits such as streambeds, beach deposits or alluvial fans. Where the gravel pits are excavated at or below the water table, they fill up with groundwater and become artificial lakes. Since gravel pit lakes follow geo logic layers, there are often many gravel pit lakes close to one another sig nificantly influencing the landscape and hydrology of a region. For example in Maine USA, 34 active and former gravel pits cover $26 \%$ of the aquifer surface (Peckenham et al., 2009). In the Netherlands, 500 gravel pit lakes give this country the highest production of gravel and sand per surface area of $108 \mathrm{t}$ per $\mathrm{km}^{2}$ (Table 1). In Italy, the gravel pit lakes along the coast near Ravenna increased the open water surface in the catchment by 6\% from 1972 to 2012 and the excavation is not yet fin ished (Mollema et al., 2012). In these two examples, as in many other areas, freshwater is a limited resource due to a limited amount of precip itation, or an irregular distribution of precipitation of throughout the year. Drainage towards the sea to prevent flooding in low lying areas such as polders and coastal zones may furthermore limit the amount of freshwa ter, as does salt water intrusion. In densely populated areas there may also be a lack of storage space for fresh water. Over the next decades, these pressures are expected to increase due to climate change and sea level rise (e.g. Oude Essink et al., 2010). Gravel pit lakes play a role in the hydro logical cycling of these above mentioned areas, letting freshwater disappear into the atmosphere by evaporation (E), but they may also form a possible storage place for freshwater (Mollema et al., 2015a). McDonald et al. (2012); Seekell et al. (2013), and Verpoorter et al. (2014) showed that lakes, including small ones, cover a much greater portion of the Earth's land surface $(\sim 3.7 \%)$ than previously believed. This has an influence on all chemical and hydrological budgets: lakes store substantial amounts of carbon $(\mathrm{C})$ in their sediments and greenhouse gas (carbon dioxide $\left(\mathrm{CO}_{2}\right)$ and methane $\left(\mathrm{CH}_{4}\right)$ emissions from lakes may almost completely offset the terrestrial carbon sink (e.g., Bastviken et al., 2011; Tranvik et al., 2009; Wetzel and Likens, 1991). Lakes play an important role in the (trace) metal cycles of soils in the catchment (Mollema et al., 2015a; Mollema 2016). Research demonstrates the sensitivity of lakes to climate and showing that physical, chemical, and biological lake properties respond rapidly to climate related changes (ACIA, 2004; Rosenzweig et al., 2007). Lakes are therefore called 'sentinels' of current climate change (Adrian et al., 2009) but it also means that lake sediments form valuable historical archives for natural and anthropogenic environmental changes. Fossil diatom assemblages may indicate changes in the input of nutrient rich water (Sayer and Roberts, 2001; Sayer et al., 2010a) and C isotopes in Daphnia in sediments may reflect methane

Table 1

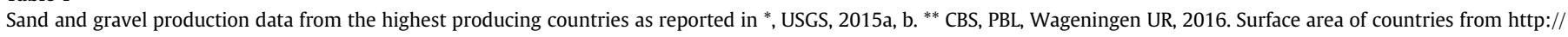
data.worldbank.org/indicator/AG.SRF.TOTL.K2, consulted on 16/07/2014.

\begin{tabular}{|c|c|c|c|c|}
\hline & $\begin{array}{l}\text { Mine production in } 2012 \\
\text { [thousand tonnes] }\end{array}$ & $\begin{array}{l}\text { Mine production in } 2013 \\
\text { [thousand tonnes] }^{*}\end{array}$ & $\begin{array}{l}\text { Mine production in } 2014 \\
\text { [thousand tonnes] }^{*}\end{array}$ & $\begin{array}{l}\text { Production per land surface area (2014) } \\
\text { [thousand tonnes per } \mathrm{km}^{2} \text { ] }\end{array}$ \\
\hline USA & 49,500 & 62,100 & 75,000 & 0.008 \\
\hline Italy & 19,800 & 16,400 & 16,400 & 0.054 \\
\hline Germany & 7770 & 7500 & 7500 & 0.021 \\
\hline Australia & 5600 & 5500 & 5500 & 0.001 \\
\hline France & 5000 & 6290 & 6300 & 0.011 \\
\hline United Kingdom & 3800 & 3760 & 3800 & 0.016 \\
\hline The Netherlands & $4500^{* *}$ & $4600^{* *}$ & & 0.108 \\
\hline World (rounded) & 140,000 & 152,000 & 165,000 & 0.001 \\
\hline
\end{tabular}


availability in lake water (Schilder et al., 2015). The relative abundance of $\mathrm{C}$ and nitrogen $(\mathrm{N})$ and their isotopes points to the source of organic matter in the form of algae and vegetation while particular organic molecules of sterol and stanol reveal the presence of sewage and distinguishing that from vegetation sourced organic matter (Vane et al., 2010). Lakes in general, however, are not mentioned in the latest reports on climate change (IPCC, 2013) and gravel pit lakes do not (yet) appear in databases of lakes (ILEC, 2014). Although in some areas (e.g. River Trent, Attenborough lakes, UK), the extraction of gravel from river beds has occurred almost continuously since Roman times, most gravel pit lakes that formed due to gravel extraction are less then hundred years old, young compared to most natural lakes (Bridgland et al., 2014; Mollema, 2016; Muellegger et al., 2013). Gravel pit lakes are therefore a relatively new environmental phenomenon, and little work has been done to investigate long term en vironmental concerns (Fang et al., 2009, 2010; Miller et al., 1996; Shevenell et al. 1999). Although the recycling of concrete has become common (CMRA, 2014), new gravel pits are still being created. Because of new uses for gravel and sand, for example as proppant in hydraulic fracturing, the demand in the USA for sand has increased more than 50\% between 2012 and 2014 (Table 1, USGS, 2015a; 2015b).

After excavation activities have ceased, gravel pit lakes can be used for canoeing, fishing (Zhao et al., 2015) and other aquatic sports, such as long distance swimming (Standiano Lake, Ravenna, Iastour, 2014). However many older gravel pit lakes are unsafe to use in this way because of the steep edges, irregular bottom topography and upwelling of deep cold water causing people to drown (e.g. Neilson, 2013). Eutrophication can affect water quality in gravel pit lakes in a negative way with blooms of cyanobacteria (Codd, 2000). In the tropics, open water bodies often are places where diseases are transmitted, for example schistosomiasis (also called bilharzia, snail fever, or Katayama fever) which have part of their lifecycle in water; or malaria which is transmitted by water related vectors (WHO, 2014). Creating lakes where there used to be an aquifer may increase the risk of occurrence of these water borne illnesses. Gravel pit lakes offer many ecosystem services especially but not only if they become a nature reserve as the Attenborough Nature Reserve in Notting hamshire, Derbyshire, UK that received the designation of a Site of Special Scientific Interest (SSSI) but that was also listed as one of the top ten eco destinations in the world (Andrews and Kinsman, 1990; BBC, 2007). Where many gravel pit lakes occur in the same area with rep lication of size, depth, geological setting and more, they can be useful for ecosystem scale research and comparisons (e.g. Cross et al., 2014; Jones et al., 2016; Vane et al., 2010). The artificial lakes offer also the possibility for building waterfront houses as for example in the Cotswold Waterpark, Gloucesteshire, UK (Waterpark, 2014). Gravel pits have been used or con sidered for use as a place to dispose of wastewater or dredging sludge (in Michigan, Blener, 1979; Switzerland, Lemann, 2008; The Netherlands, Deskundigencommissie zandwinputten, 2009: Implementatieteam besluit Bodemkwaliteit, 2010; Delleur, 2010) or debris from land clearing and even salt (Peckenham et al., 2009). Gravel pit lakes may be used for artificial recharge and recovery of drinking water as has been done in The Netherlands (Mollema et al., 2015a) and is being considered in the USA (Fang et al., 2009, 2010). They may also serve as flood retention areas where particulate matter settles (Cross et al., 2014). With the fast technological development of alternative energy sources such as solar en ergy, the need for (seasonal) storage of heat is rising and gravel pit lakes may be one of the places to consider for heat storage (Novo et al., 2010).

In this review, we present a synthesis of past research on the role of gravel pit lakes and discuss current perspectives for new research in this field. Sometimes this same type of lake is referred to in the literature as 'urban', 'shallow', 'hypertrophic' or 'nutrient rich' without referring to their origin. In this paper however we use the term 'gravel pit lakes' to indicate artificial lakes that formed due to excavation of gravel or coarse sand. We evaluate the effect of climate and land use change on the water budget and specific hydrochemical processes occurring in gravel pit lakes. We give examples of values for hydrological cycling of gravel pit lake systems in temperate and Mediterranean climate zones, obtained from a case study in the Netherlands (Mollema et al., 2015a) and in Italy (Mollema et al., 2015b). We compare the hydrochemical characteristics of gravel pit lakes with published hydrochemistry data of different types of natural lakes and other types of surface waters. The fact that hydrochemical studies are published in an enormous spread of scientific journals in the fields of hydrology, environmental sciences, geochemistry, hydrogeology, ecology, and biology and the fact that many different units of measurements are used to express con centration of chemical elements makes it time consuming to compare the hydrochemistry of gravel pit lakes to natural lakes or other types of water. By means of this review we hope to contribute to an under standing of the hydrological, and (bio)chemical cycling in gravel pit lakes, their ecological functioning as well as the effect of multiple gravel pit lakes on a catchment.

\section{Geological settings}

\subsection{Gravel pit lakes versus natural lakes}

An important difference with natural lakes is that gravel pit lakes abruptly dissect the geological layering. Natural lakes form typically along particular geologic layers or by tectonic causes. Gravel and sand deposits are very permeable and so gravel pit lakes permit significant exchange of surface water with groundwater. Gravel pit lakes may be relatively shallow with a depth of 2 to $3 \mathrm{~m}$ (Cross, 2009) or 7 to $12 \mathrm{~m}$ (Mollema et al., 2015b) but they can be as deep as $40 \mathrm{~m}$ (Mollema et al., 2015a). Natural lakes can have a depth of up to hundreds of meters and they typically have a relative depth to surface area less than $5 \%$, whereas gravel pit lakes commonly have relative depths to surface area ranging between 10 and 40\% (Wetzel and Likens, 1991; Doyle and Runnells, 1997). As a consequence gravel pit lakes have relatively a larger surface area across which interaction occurs with groundwater and/or river water.

The most common annual bottom sedimentation rates in natural lakes range from 1 to $5 \mathrm{~mm}$ /year. Thus natural lakes with a depth between 10 and $500 \mathrm{~m}$ can be expected to possess a life span between $10^{4}$ and $10^{5}$ years (Löffler, 2003) and are filled up by sand, clay and gravel brought in by rivers, atmospheric deposition and transport of chemicals with groundwater and organic detritus depositing on the bot tom. Reservoirs tend to fill up by sediments that are trapped behind dams with rates that typically vary from 0.03 to $1 \mathrm{~mm}_{\text {year }}{ }^{-1}$ (e.g. De Vente et al., 2005; Minear and Kondolf, 2009).

Many gravel pit lakes are isolated from rivers and may fill up by at mospheric deposition and influx of minerals in groundwater, and precipitation of organic material and metal oxides on the bottom and occasional slumping of steep edges. Often gravel pit lakes are in relative ly flat floodplains, so there is limited inwash of water and material com pared to natural lakes with steeper catchments. The inflow of metals in gravel pit lakes with groundwater can be up to 1000s of $\mathrm{kg} \mathrm{year}^{-1}$ (Mollema et al., 2015a) but this results in sedimentation rates of only $2 \times 10^{-9} \mathrm{~mm}$ year $^{-1}$. All this suggests that the sedimentation rate into isolated gravel pit lakes is relatively small and these types of gravel pit lakes are likely to last at least a few thousand years.

\subsection{Depositional environment}

Alluvial fans are one type of geologic deposit that is mined for its gravel and sand. They consist of a fan or cone shaped deposit of sediment built up by streams (Boggs, 1987). Because of the steep topographic gradients in current alluvial fans, lakes typically do not form when the gravel is mined. Instead gravel in current fluvial deposits occurs in different morphological parts of rivers (Boggs, 1987). When these are mined, they often form gravel pit lakes (Fig. 1a). Fluvial streambeds, stream terraces and floodplains all contain gravel that can be mined (e.g. along the Meuse, Netherlands; Mollema et al., 2015a: along Donau River, Weilhartner et al., 2012). In north Europe (Van 
West

East

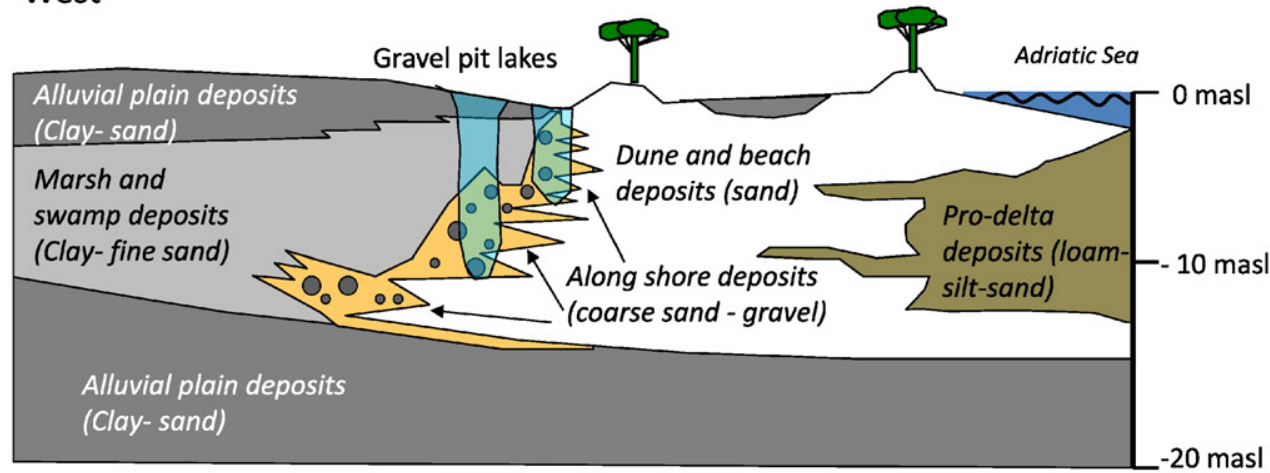

a

$12 \mathrm{~km}$

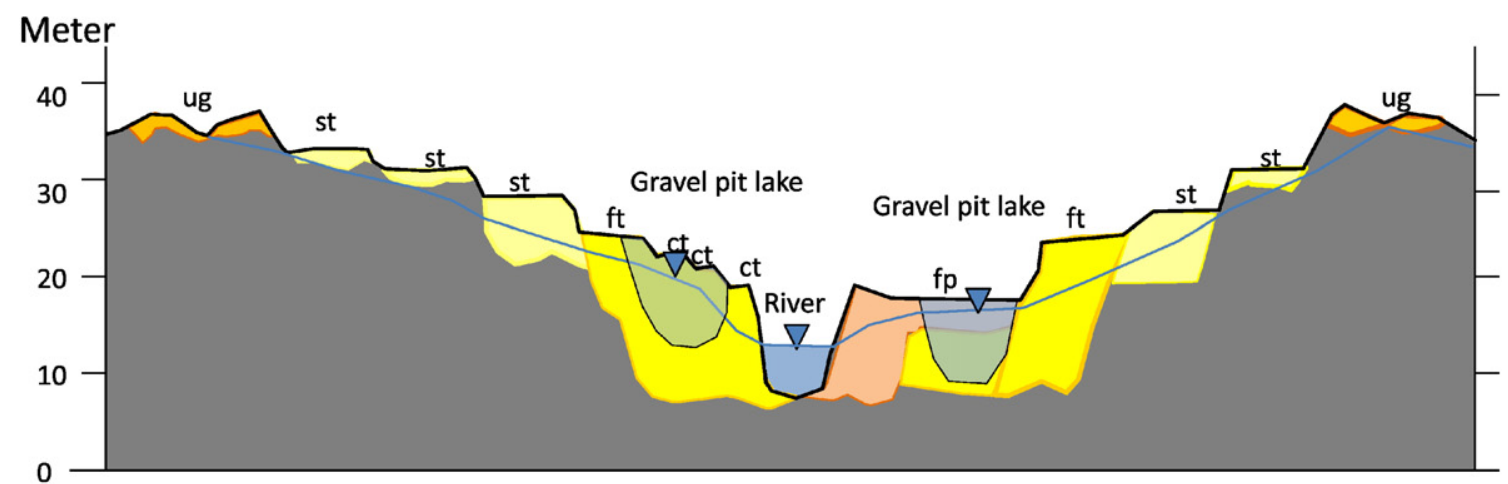

b

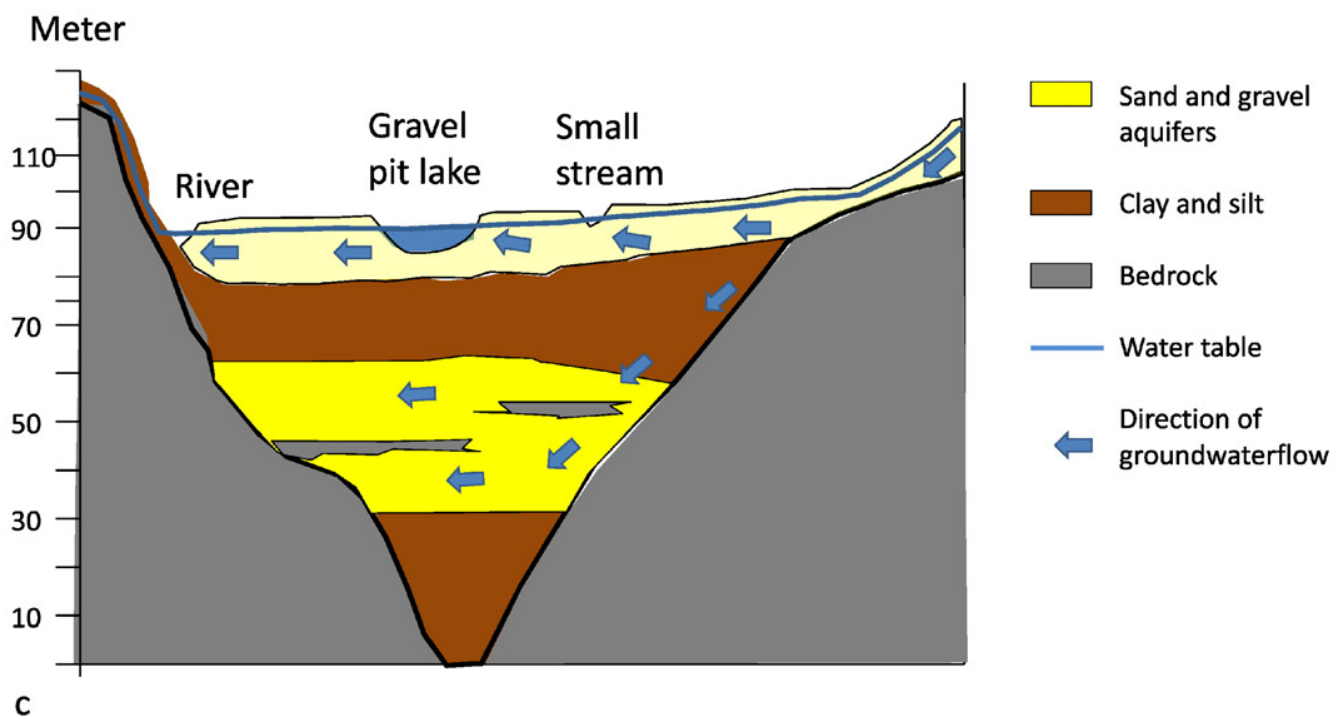

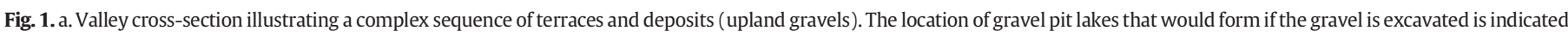

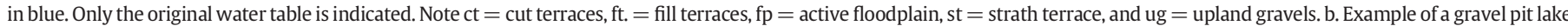

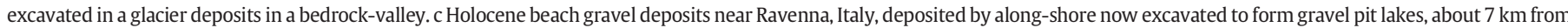
the current shoreline.

Balen and Busschers, 2010; Waterpark, 2014), North America (Maine, Peckenham et al., 2009), and Canada (Stephenson et al., 1988) thick accumulations of sand and gravel were deposited in front of advancing glaciers during the ice ages (Boulton, 1986). The gravel was or still is being accumulated in glacial terraces, outwash plains, eskers, and kame terraces (Boulton, 1986) that may form gravel pit lakes when excavated (Fig. 1b). Also currently new gravel deposits are being formed at the margins of glaciers (e.g. Shugar and Clague, 2011) but these de posits are usually above the water table. Both current and fossil (raised) beach deposits may contain gravel (Bluck, 2011) and are mined with gravel pits for example along the coast of the north Adriatic in Italy (Fig. 1c, Mollema et al., 2013a, 2015b). Weathered bedrock is found to 


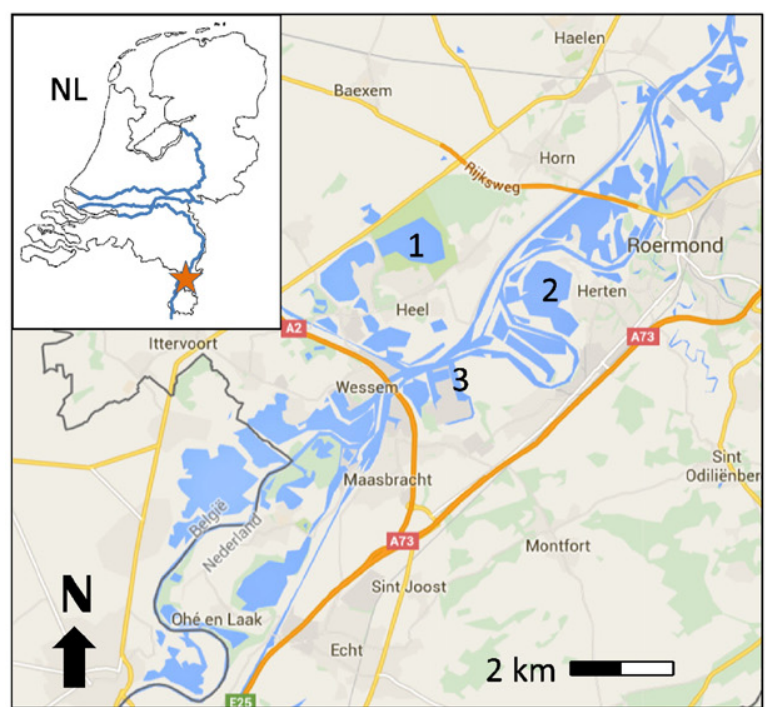

a

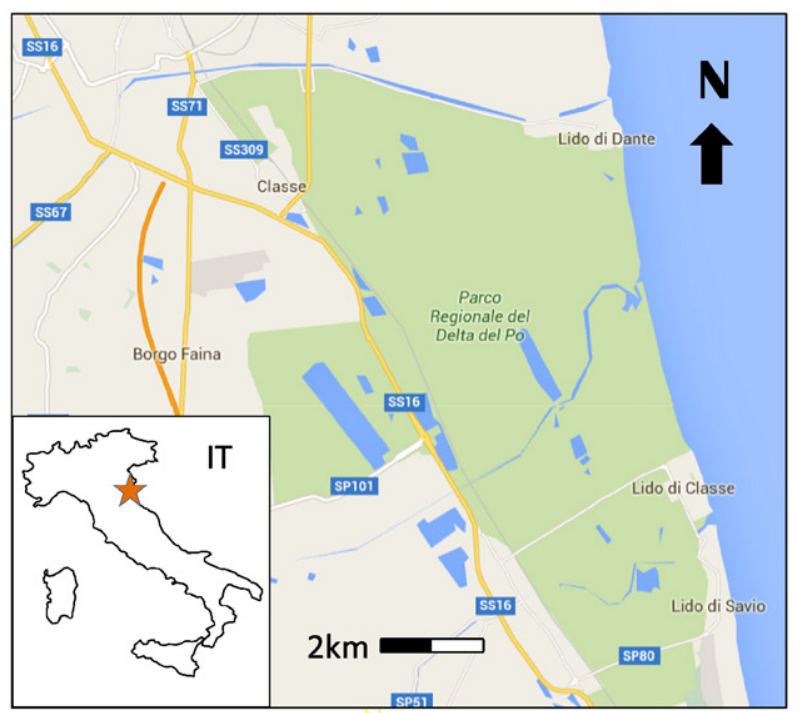

b

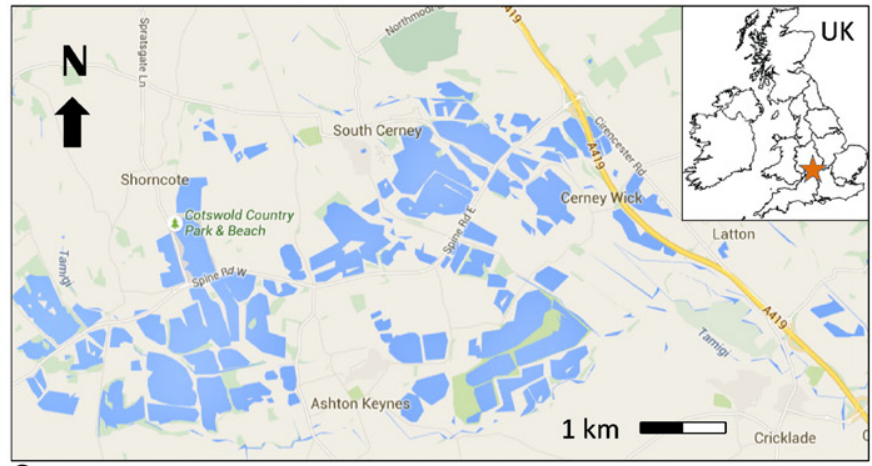

$\mathbf{C}$

Fig. 2. a Google map of part of the Meuse Valley, south Netherlands that contains about 70 gravel pit lakes (lat $31 \mathrm{U} 703349 \mathrm{~m}$ long E5672291). The inset shows approximate location in the Netherlands (NL). The following types of lakes are indicated: 1 . Flow-through gravel pit lake, separated from river 2.Gravel pit lakes in active and abandoned meanders. 3. Gravel pit lake in open connection to a river. b. Google map of gravel pit lakes along the Adriatic coast (Italy lat. 33T281595, long. E4915220). The lakes are aligned along ancient beach deposits parallel to the current coast line, 5-7 km inland. The inset shows location in Italy (IT). C. Google map image of gravel pit lakes in glacier deposits with new housing developments. The inset shows approximate location in the United Kingdom (UK; Gloucestershire; Cotswold Waterpark lat 30 U 573671, long E5723155). be a source of sand and gravel in Australia (Stubbs and Smith, 1997). Gravel deposits are also found and mined offshore (Cattaneo and Steel, 2003; Kubicki et al., 2007).

\section{Hydrology of gravel pit lakes}

\subsection{Drainage pattern and residence time}

Gravel mining along the streambed of rivers disrupts the continuity of sediment transport by rivers and changes the river morphology by creating local areas of deposition and erosion (Kondolf, 1997) and changing the natural morphology into an anthropoce11585/566462ne landscape with different incision rates (e.g. Florsheim et al., 2013). The presence of gravel pit lakes changes the hydraulic gradients in the surrounding aquifer, espe cially if the lakes are created in a sloping area or in a low lying plain. The lakes themselves are by definition a surface of equipotential head. Be cause the drainage pattern of the area changes (Figs. 2 and 3), a gravel pit lake may cause the rise or the lowering of the water table over a large area (Mas Plaa et al., 1999). If the gravel pit lakes are in a low lying coastal plain, they will enhance the need for drainage. This can enhance salt water intrusion up to several kilometers inland as observed by Mas Plaa et al. (1999) and confirmed by modeling studies (Mollema et al. 2010; Werner et al., 2013) especially if sea level is rising.

Gravel pit lakes may abruptly intersect geologic formations such as a confining clay layer or buried paleo channels. This will enhance the transport of water and its solutes and may disrupt the original stratification of groundwater types (Mollema et al., 2013a; Stuyfzand, 1999). The residence time of water in natural lakes varies from 1343 years for a large lake as Titicaca $\left(850 \mathrm{~km}^{3}\right)$ while it is only 0.4 year for a small pond $\left(0.013 \mathrm{~km}^{3}\right)$ (Löffler, 2003). The residence time of water in gravel pit lakes documented so far, ranges from 0.03 to 0.04 year for river con nected gravel pit lakes (Cross et al., 2014) and 0.1 to 2 years for ground water fed or flow through gravel pit lakes (Löffler, 2003; Mollema et al., 2015a, b; Weilhartner et al., 2012). The residence time of water in gravel pit lakes may increase with time as the permeability of its banks chang es due to clogging. The (enhanced) groundwater flow transports chem ical elements into the lake that in part may precipitate and clog the bottom or the downstream bank of the lake by accumulation of suspended solids, precipitates, the formation of gas bubbles and sedi ment compaction (Baveye et al., 1998). Besides the physical and chem ical clogging mechanisms, nutrient inflow leads to the accumulation of biomass and this may cause biological clogging as observed in Austrian gravel pit lakes (Weilhartner et al. 2012). The clogging is a highly tem poral and spatial variable process that will vary from lake to lake but the deposition of particulate matter (organic and inorganic) is observed to contribute up to one third of the organic matter internally produced in the upper sediment layer (e.g. macrophyte rhizomes, microalgae, biofilms; Hoffmann and Gunkel, 2011). The occurrence of redox reac tions in the aquifer system downstream of gravel pit lakes trigger a chemical clogging process when (sub)oxic lake water and anoxic groundwater mix (Bustos Medina et al., 2013; De la Loma Gonzalez et al., 2013) as it does in regular river bank filtration (Hiscock and Grischek, 2002; Schlieker et al., 2001). In contrast to river bank and bed sediments, periodic resuspension due to floods does not occur nat urally in lowland lakes and flow regulated lowland rivers (Hoffmann and Gunkel, 2011) or gravel pit lakes, so the clogging in banks of gravel pit lakes may be permanent.

We can distinguish several types of gravel pit lakes depending on the hydrogeologic setting (Figs. 2 and 3). In a river basin, there may be ex cavations that create a lake in contact with the river (Bayram and Önsoy, 2015; Cross et al., 2014; Kondolf, 1997), in a meander, or an old gravel bar (Fig. 2). A lake may have formed in an abandoned mean der (Fig. 3d). Gravel pit lakes may be topographically higher than the stream and not directly connected to the river (Mollema et al., 2015a; Weilhartner et al., 2012; Fig. 3c). If groundwater infiltrates on one side of such a lake and flows out of the lake on the other side, we call it a 

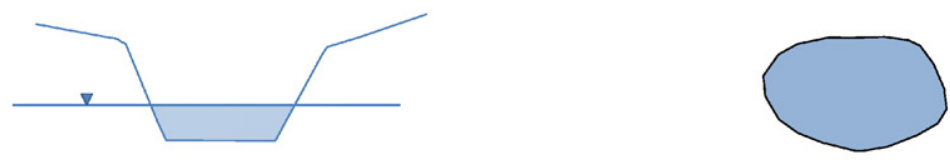

Gravel pit lake is to all effects an 'outcrop' of the water table.

Gravel pit lake formed where the floor of the pit lies below the water table on groundwater divide or in impervious rock. There

a is no lateral flow.

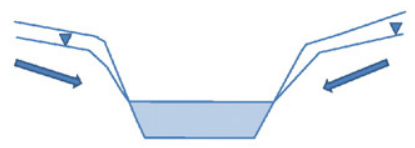

Terminal gravel pit lake: water flows from all sides into the gravel pit lake

b

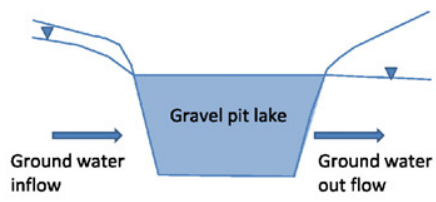

Drainage into and out of a gravel pit lake by latera groundwater flow, flow through lake.

C

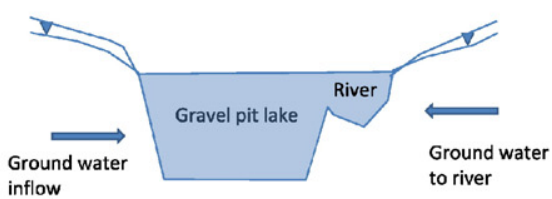

Drainage into gravel pit lake and river, open connection between gravel pit lake and river.

d

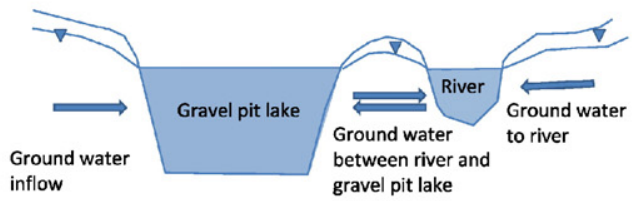

Drainage into gravel pit lake and river, flow between gravel pit lake and river. Gravel pit lake could be an oxbow lake.
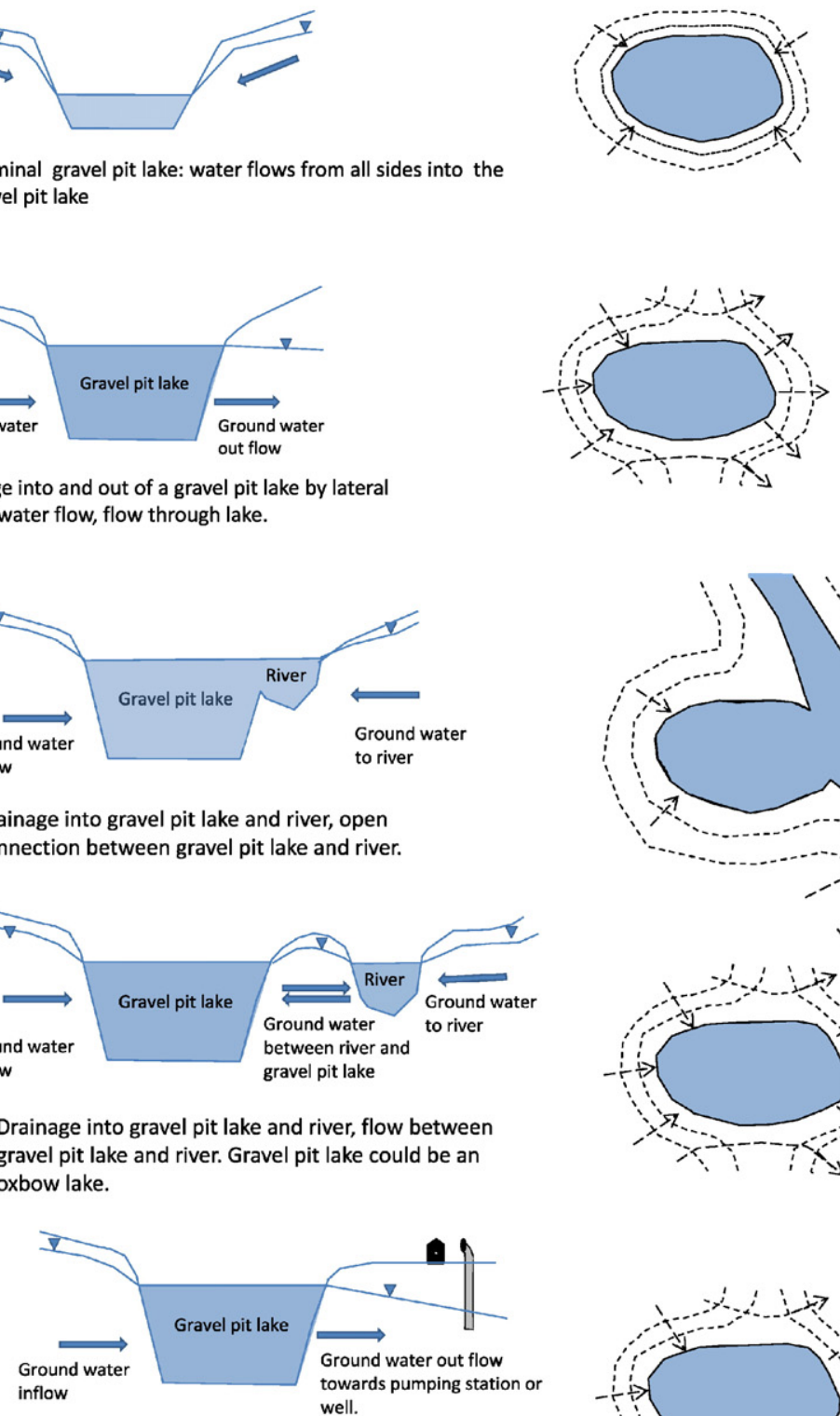

Drainage into and out of a gravel pit lake by lateral groundwater flow, flow through lake driven by artificial drainage or pumping.
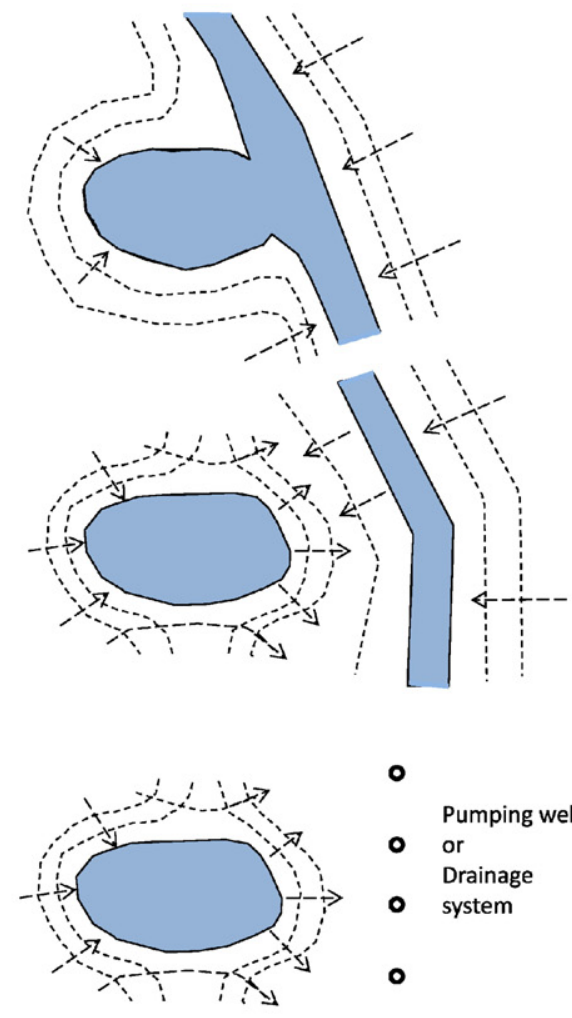

o

Pumping wells

- or

Drainage

- system

$f$

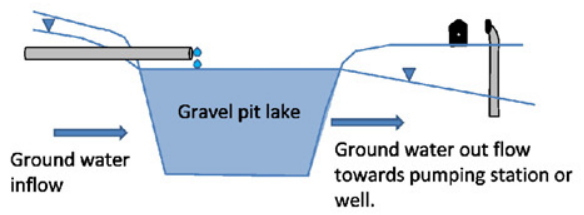

Drainage into and out of a gravel pit lake by lateral groundwater flow, artificial recharge through pipe system, flow through lake driven by artificial drainage or pumping.

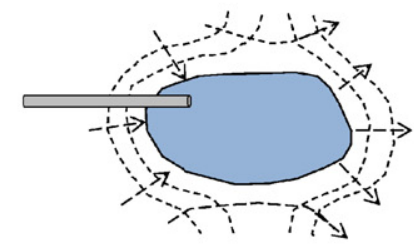

○

Pumping wells

- or

Drainage

- system 
"flow through lake". A flow through lake may also form under the in fluence of an artificial drainage network as is the case in the gravel pit lakes excavated along the coast of the Adriatic Sea (Mollema et al., $2015 \mathrm{~b}$ ). Whether or not gravel pit lakes are isolated or connected to a river influences the chemical composition of the lake water, including the nutrient supply and therefore the ecosystem (Cross et al., 2014 and see Section 5).

\subsection{Water budget}

Gravel pit lakes increase the extent of surface water in a catchment, and therefore the area from which direct evaporation can occur (Fig. 4). Evaporation (E) depends on many different climate variables: wind ve locity, the relative humidity of air, and vapor pressure deficit, (e.g. Mohamed et al., 2012; Van Heerwaarden et al. 2010 a, b) while the ac tual evapotranspiration $\left(\mathrm{ET}_{\mathrm{a}}\right.$ ) from a vegetated piece of land also depends on the physiologic characteristics of the vegetation (radiation properties and physical resistances in the plant's internal pathway), the proportion of the area covered by vegetation and by bare soil as well as the soil water potential in the root zone (Mohamed et al., 2012). In most climate settings $\mathrm{E}$ is larger than $\mathrm{ET}_{\mathrm{a}}$ of a piece of vegetated land since the resistance to $\mathrm{E}$ is smaller without vegetation or soil (Maidment, 1992; Mohamed et al., 2012; Penman, 1948). Emergent aquatic vegetation of wetlands that is present in many (shallow) gravel pit lakes is thought by some to have a larger $\mathrm{ET}_{\mathrm{a}}$ than $\mathrm{E}$ in particular circumstances such as in a (sub)tropical and temperate winter climate, especially at low wind speeds (Mohamed et al., 2012) but this issue is controversial (e.g. Maltby and Barker, 2009; Mohamed et al., 2012). In groundwater fed gravel pit lakes, typically only the available energy of the sun limits evaporation since inflowing groundwater replaces the evaporated water.

\section{Chemical cycling}

\subsection{Chemistry of gravel pit lake water versus other types of surface and ground water}

To try to understand whether the hydrochemistry of gravel pit lakes is different from natural lakes and other waters, we compared the water quality of Dutch and Italian gravel pit lakes studied by Mollema et al. (2015a, b), of Austrian gravel pit lakes studied by Muellegger et al. (2013) and Weilhartner et al. (2012), and additional data on British gravel pit lakes (Cross et al., 2014), with water quality of rivers, various types of natural lakes (marl lakes, alpine lakes, nutrient rich lakes and more), groundwater and seawater (Table 2 ). We discuss the processes that are responsible for the hydrochemical differences between gravel pit lake and other water types. Precipitation contains less dissolved elements than gravel pit lake water (Table 2). River water contains more dissolved substances than precipitation but usually less than gravel pit lake water. The strongest enrichment of water occurs usually as groundwater due to water rock interactions especially in coastal set tings. These include the area of groundwater discharge into the sea, the so called subterranean estuary, where seawater with high concentration of solutes has a large influence (Fig. 6 and Table 2). When groundwater exfiltrates into surface water of a different chemical composition, acidity and alkalinity, chemical reactions occur that include but are not limited to the precipitation and dissolution of minerals on the lake bottom. Gravel pit lakes are an unnatural type of surface water that interrupts the natural flow of solutes towards the rivers, lakes or the sea and in some cases this may result in a relative enrichment of certain elements, in other cases a relative depletion of certain elements. Fig. 5a and b illustrate this for two particular case studies where gravel pit lake water is depleted in Iron (Fe) and Ca compared to groundwater.

Lake water chemistry is variable and changes with the particular set ting of a lake. We have therefore indicated the type of lakes and the number of lakes involved as described in the original publications (Table 2 ). The range of $\mathrm{pH}$ values observed in gravel pit lakes ( $\mathrm{pH} 7.210 .4$ ) is slightly different and smaller than the range of $\mathrm{pH}$ of the reviewed natural lakes (pH 5.0 9.0) (Fig. 6a, Table 2). The pH of gravel pit lakes is higher than that of typical alpine or boreal natural lakes but similar to natural 'marl' lakes. A much larger range in Ca concentration is (so far) observed in natural lakes than in gravel pit lakes, which may be explained by the fact that natural lake studies include high alpine, bore al or arctic settings as well as unconsolidated sediments with hard water or 'marl' lakes. The gravel pit lakes included in this comparison by definition are in unconsolidated sediments and they are located in li thologies that include carbonate grains which causes the high alkalinity of ground and lake water. The alkalinity of the gravel pit lakes is high compared to that of natural lakes except for that of hard water (marl) lakes (e.g. Wiik et al., 2013). In coastal saline gravel pit lakes we ob served the highest $\mathrm{HCO}_{3}$ values (727 $812 \mathrm{mg} \mathrm{L}^{-1}$; Table 2). High $\mathrm{HCO}_{3}$ concentrations in this setting are caused by current and past redox reactions and Calcium carbonate $\left(\mathrm{CaCO}_{3}\right)$ dissolution (Mollema et al., 2015a, b; 2013a, b). Also in a non coastal setting, the $\mathrm{HCO}_{3}$ con centration of gravel pit lakes is high (103 $147 \mathrm{mg} \mathrm{L}^{-1}$ ). The gravel pit lake and natural lake studies included in this review show that lake water typically has a low concentration in dissolved metals. The maxi mum Fe concentration observed so far in natural lakes is higher and the minimum Zinc $(\mathrm{Zn})$ concentration is lower in gravel pit lakes com pared to natural lakes (Fig. 6e and f, Table 2). Instead groundwater in certain circumstances may have very high concentrations in dissolved metals (Table 2). Seawater contains typically high concentrations of sol utes such as chloride $\left(\mathrm{Cl}^{-}\right)$and sulfate $\left(\mathrm{SO}_{4}{ }^{-}\right)$but metals and other trace elements tend to disappear from the water column.

If we compare three systems of gravel pit lakes with one another (low alpine river deposits, Muellegger et al., 2013; lowland river deposits Mollema et al., 2015a; coastal plain beach deposits Mollema et al., 2015b), we find that the $\mathrm{pH}$ is fairly high in all three lake systems 7.2 8.7 (Table 2), the largest nitrate $\left(\mathrm{NO}_{3}\right)$ and Fe concentrations are observed in the alpine lake setting and the highest dissolved Ni concentration in the Italian coastal gravel pit lakes. Cross et al. (2014) found that gravel pit lakes connected to a river have higher $\mathrm{NO}_{3}$ and Total $\mathrm{P}$ concentrations than isolated gravel pit lakes in line with the general ob servation that $\mathrm{NO}_{3}$ in river water may show higher concentrations of nutrients than isolated gravel pit lakes (Table 2).

Stable oxygen and hydrogen isotopes of lake water reflect the iso tope composition of the precipitation and groundwater flowing into the lakes, and the evaporation rate which causes a relative enrichment in heavy isotopes (Table 2). Therefore it is difficult to quantify how grav el pit lakes influence the stable oxygen and hydrogen isotopes of water differently from natural lakes. So far there have been carried out more studies on natural lakes in a larger range of climate and geographical lo cations and therefore the observed and published range in stable water isotope values is larger in natural lakes than in gravel pit lakes (Table 2).

\subsection{Nutrient cycling}

The nutrient cycle in a gravel pit lake includes the addition of $\mathrm{P}$ and $\mathrm{N}$ by atmospheric deposition, fertilization of the surrounding soil, sewage

Fig. 3. a. Cross sectional and map view of different types of gravel pit lakes with groundwater flow indicated by arrows. a. Gravel pit lake intersects the water table. b. Terminal pit lake (uncommon for gravel pits) c. Flow-through gravel pit lake. d. In stream gravel pit lake. e. Gravel pit lake in valley bottom. f. Gravel pit lake in an artificially drained basin. g. Artificially recharged gravel pit lake in artificially drained basin.

Modified in part from Gammons et al. (2009); Gandy et al. (2004); Mollema et al. (2015a) and Younger and Robins (2002). 


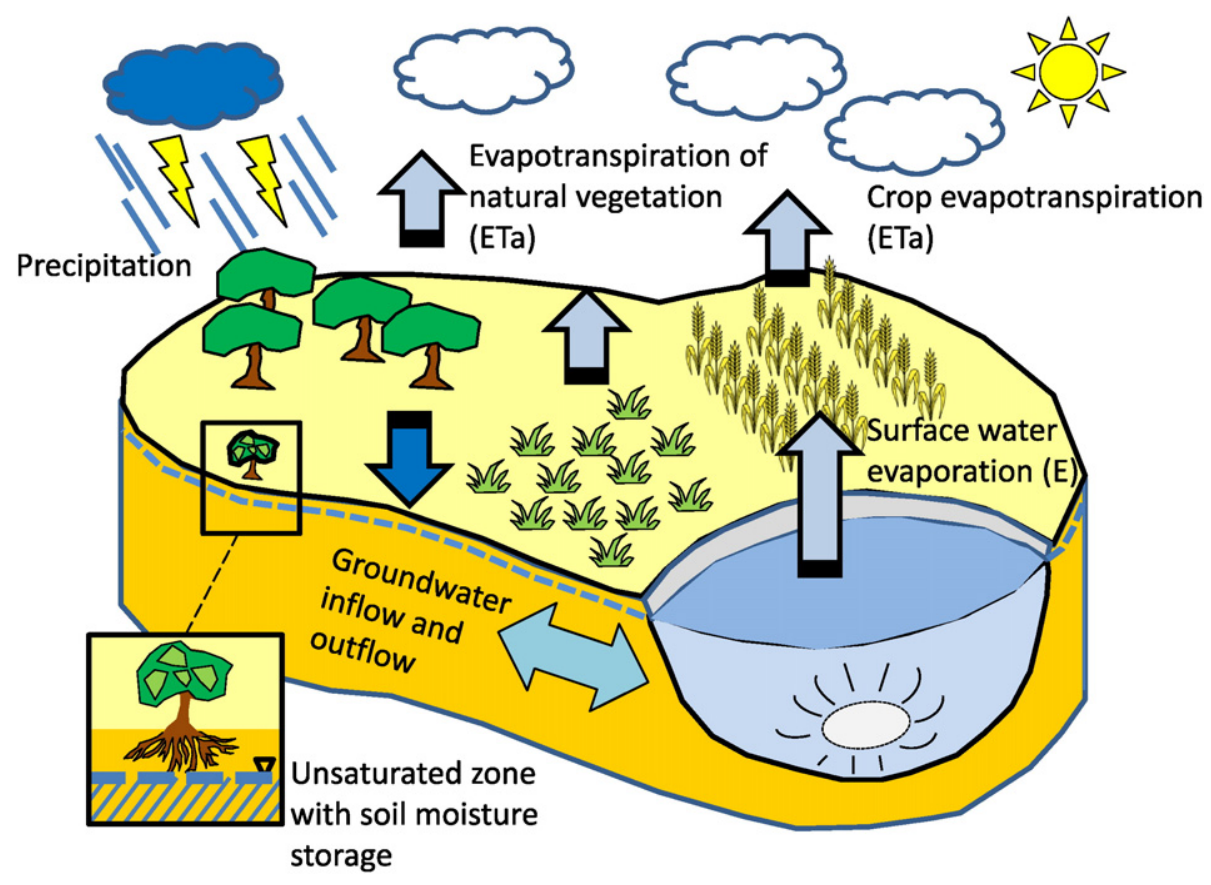

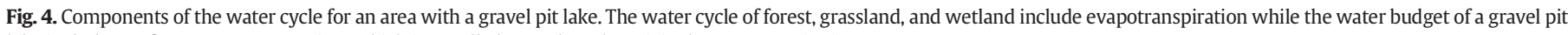
lake includes surface water evaporation, which is usually larger than the original evapotranspiration.

pollution and subsequent surface runoff, transport by rivers and/or groundwater (Fig. 7; Alvarez Cobelas et al., 1992; Vane et al., 2010). The resulting measured $\mathrm{NO}_{3}$ concentrations in gravel pit lakes range from 0.1 to $18 \mathrm{mg} \mathrm{L}^{-1}$ (Table 2), which is not as high as the amount that has been observed in fresh or brackish groundwater (up to $58 \mathrm{mg} \mathrm{L}^{-1}$; Table 2) or in river water (up to $372 \mathrm{mg} \mathrm{L}^{-1}$; Table 2). The $\mathrm{NO}_{3}$ concentration is higher than that of natural lakes not affected by land use (up to $0.7 \mathrm{mg} \mathrm{L}^{-1}$ Table 2; Sickman et al., 2003), which is logical since most gravel pit lakes are in an urban or agricultural setting and are indeed affected by land use. The presence of the gravel pit lake affects the amount of $\mathrm{N}$ and $\mathrm{P}$ in groundwater downstream, typically reducing the concentration as they turn into biomass (Alvarez Cobelas et al., 1990; Garnier and Billen, 1994; Helmer and Labroue, 1993; Weilhartner et al., 2012; Muellegger et al., 2013; Mollema et al., 2015a). The inflow and accumulation of nutrients into the gravel pit lakes may cause eutrophication with nuisance algal blooms (Section 5) and interferes with metal cycling, see Section 4.4. Organic matter in sediment strongly affects $\mathrm{PO}_{4}$ adsorption as observed in pit lakes in a former lignite mine (Herzsprung et al., 2010), with the light fraction or ganic matter (LFOM) playing a key role in nutrient cycling. The chemistry and kinetics may change over time: if LFOM is removed, $\mathrm{PO}_{4}$ adsorption decreases (Wang and Mulligan, 2006). Sulfide may take the place of $\mathrm{P}$ bound to iron in sediments during reduction processes (Lamers et al., 2002, 2013; Smolders and Roelofs, 1996).

\subsection{Carbon and Ca cycling}

Inland waters including gravel pit lakes play an important role in the carbon cycle since they are extremely active sites for transport, transformation, and storage of considerable amounts of carbon received from the terrestrial environment despite a limited surface area (Nõges et al., 2016; McDonald et al., 2013; Marcé et al., 2015; Tranvik et al., 2009). Many processes are recognized to play a role in carbonate bicarbonate equilibrium of natural lakes (e.g. Cole et al., 2007; Kortelainen et al., 2007) that also will play a role in gravel pit lakes although no specific studies on all components of the carbon budget in gravel pit lakes have yet been carried out (Fig. 8): uptake of atmospheric $\mathrm{CO}_{2}$ in water, release of $\mathrm{CO}_{2}$ to the atmosphere (e.g. Raymond et al., 2015), carbonate $\left(\mathrm{CaCO}_{3}\right)$ dissolution by $\mathrm{CO}_{2}$ and $\mathrm{H}_{2} \mathrm{O}$, weathering of silicate minerals (Liu et al., 2010), the photosynthetic uptake of dissolved inorganic carbon (DIC) by aquatic organisms and assimilation of C, Ca and Silicon (Si) by organisms including plankton, diatoms and molluscs and deposition on the lake bottom (Einsele et al., 2001; Iglesias Rodriguez et al., 2008); anaerobic degradation of organic matter by specialized methanogenic microbes and subsequent partial methane $\left(\mathrm{CH}_{4}\right)$ oxidation by methanotrophic bacteria in oxic surface sediments or in the water column (Bastviken et al., 2011; Blees et al., 2015; Weilhartner et al., 2012) as well as biological methane production in lake waters (e.g. Blees et al., 2015).

The relative contribution of various fluxes to the carbon cycle of lakes varies with latitude, type of bedrock and whether or not the lake is a reservoir (Marcé et al., 2015; Tranvik et al., 2009) and with salinity, and $\mathrm{pH}$ of lake water (Duarte et al., 2008). The gravel pit lakes reviewed in this paper are most similar to hard water lakes or reservoirs in a tem perate climate and so the largest components in their C cycle are most likely the in and outflow of DIC with groundwater and the storage in the lake bottom sediment (Marcé et al., 2015; Tranvik et al., 2009). The more so since the amount of groundwater flow into gravel pit lakes can be very large compared to the other water fluxes (Mollema et al., 2015a, b; Weilhartner et al., 2012).

Einsele et al. (2001) found that although the area of lake basins is only about $0.8 \%$ of the ocean surface or $2 \%$ of the land surface, a surpris ingly high amount of atmospheric carbon is buried in lake sediments, which amounts to $0.07 \times 10^{15} \mathrm{~g}$ of $\mathrm{C}$ per year, more than one fourth of the annual atmospheric carbon burial in the modern oceans. This burial is mainly accomplished by rapid accumulation of lacustrine sediments and a very high preservation factor, which is on average 50 times higher than that in the oceans (Einsele et al., 2001). Comparing among different types of natural lakes and a (agricultural) water reservoir, Tranvik et al. (2009) found that the carbon stored in the lake sediments was higher in the reservoir than in natural lakes. In this sense, the creation of gravel pit lakes provides more available sites for carbon burial. Many lakes and reservoirs are supersaturated with $\mathrm{CO}_{2}$ which has been attributed partly to the accumulation of inorganic carbon where respiration exceeds photosynthesis (Duarte and Prairie, 2005) and to carbonate weathering in the catchment (when lake water alkalinity is 


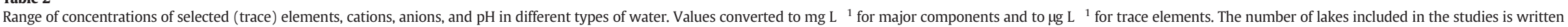
between square brackets; [rev] means the quoted paper is a compilation of multiple studies on different types of lakes; types of lakes are copied from articles.

\begin{tabular}{|c|c|c|c|c|c|c|c|}
\hline & Precipitation & River & Groundwater fresh & Natural lakes & Gravel pit lakes & $\begin{array}{l}\text { Coastal brackish } \\
\text { groundwater }\end{array}$ & Sea/ocean \\
\hline $\mathrm{pH}$ & $\begin{array}{l}4.1-6.3^{1} \\
4.5-7.6^{17}\end{array}$ & $5.5-8.4^{7}$ & $\begin{array}{l}5.0-7.6^{4} \\
7.1-7.8^{3} \\
4.4-6.5^{20}\end{array}$ & 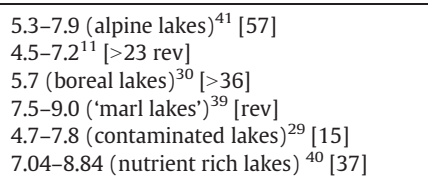 & $\begin{array}{l}7.2-8.6^{3}[5] \\
7.5-8.6^{4}[3] \\
7.9-8.7^{5}[2] \\
7.2-10.4^{38}[6] \\
8.27^{32}[1]\end{array}$ & $6.0-7.7^{5}$ & $8.1^{10}$ \\
\hline TDS [mg L $\left.{ }^{1}\right]$ & & $\begin{array}{l}\text { 4-1000 (surface waters together) } \\
99.6 \text { (unpolluted) }-110.1^{11}\end{array}$ & & & & & $20,000-40,000^{6}$ \\
\hline Al $\left[\mu \mathrm{g} L{ }^{1}\right]$ & $13.2^{14}$ & $13.2^{13}$ & $\begin{array}{l}0.7-1842^{4} \\
0-8094^{21} \text { (max values in } \\
\text { acid soils) }\end{array}$ & $\begin{array}{l}\text { 270-1349 (acidified lakes) }{ }^{26}[4] \\
0-33\left(\text { soft water lake) }{ }^{27}[1]\right.\end{array}$ & $\begin{array}{l}0.7-19.5^{4}[3] \\
10-30^{5}[2]\end{array}$ & $0-100^{5}$ & $0.08-1.05(\text { mean about } 0.05)^{2}$ \\
\hline As $\left[\mu g \mathrm{~L}^{1}\right]$ & $0.025^{14}$ & $\begin{array}{l}0.15-45 \text { (high for polluted rivers) up to } \\
21,800 \\
\text { for rivers fed by As rich groundwater }{ }^{10}\end{array}$ & $\begin{array}{l}0.5-10 \text { baseline }^{10} \\
10-5000 \text { As rich }^{10}\end{array}$ & $0.06-9.2^{10}[\mathrm{rev}]$ & $\begin{array}{l}0.3-4.3^{4}[3] \\
12-13 \mathrm{~L}^{5}[2]\end{array}$ & $\begin{array}{l}0-48^{5} \\
0.7-3.8^{10}\end{array}$ & $\begin{array}{l}1.4-1.8^{2} \\
1-3.7^{10}\end{array}$ \\
\hline $\mathrm{Ba}\left[\mu \mathrm{g} \mathrm{L}{ }^{1}\right]$ & & $4-17^{8}$ & $\begin{array}{l}16^{9} \\
26-154^{24}\end{array}$ & & $748-1768^{5}[2]$ & $51-640^{5}$ & $4-20(\text { mean } 15)^{2}$ \\
\hline $\mathrm{Ca}\left[\mathrm{mg} \mathrm{L}{ }^{1}\right]$ & $\begin{array}{l}0.1-0.4^{4^{6}} \\
0.1-5.3^{17}\end{array}$ & 13-3727 (median 401) ${ }^{7}$ & $\begin{array}{l}4-60(\text { unsaturated soil })^{1} \\
2-96(\text { saturated soil })^{1} \\
8.3-89.5^{4}\end{array}$ & $\begin{array}{l}1.4-2.3(\text { boreal lakes })^{30}[36] \\
>30(\text { marl lakes })^{31}[\text { rev }]\end{array}$ & $\begin{array}{l}29.1-56.3^{4}[3] \\
56.6-136^{5}[2]\end{array}$ & $104.1-436.5^{5}$ & $416^{10}$ \\
\hline $\mathrm{Fe}\left[\mu \mathrm{g} \mathrm{L}{ }^{1}\right]$ & $20.1^{14}$ & $53.9^{13}$ & $\begin{array}{l}0-27,925^{1} \\
100-18,200^{4}\end{array}$ & $\begin{array}{l}>11-1117 \text { (glacier formed lake })^{18}[1] \\
2.2-10.1(\text { soft water lake })^{27}\end{array}$ & $\begin{array}{l}5-138^{3}[5] \\
2-76^{4}[3] \\
72-77^{5}[2]\end{array}$ & $335-13,500^{5}$ & $0.001-0.11(\text { mean } 0.03)^{2}$ \\
\hline $\mathrm{Cl}\left[\mathrm{mg} \mathrm{L}{ }^{1}\right]$ & $0.2-9.8^{1}$ & $0-16.9(\text { mean }=0.1)^{7}$ & $6.3-55.6^{4}$ & $0.4-9.9^{11}[>23 \mathrm{rev}]$ & $\begin{array}{l}38.1-45.8^{4}[3] \\
2920-4760^{5}[2]\end{array}$ & $465-16,500^{5}$ & $18883^{2}$ \\
\hline $\begin{array}{l}\mathrm{HCO}_{3}[\mathrm{mg} \\
\mathrm{L}^{1}\end{array}$ & $0.5-1.5^{1}$ & $\begin{array}{l}17.9-183.0^{11} \\
188-435^{5}\end{array}$ & $\begin{array}{l}0-305.1^{1} \\
5-198.8^{4}\end{array}$ & $\begin{array}{l}10.5-140.1^{11}[>23 \mathrm{rev}] \\
54.9-85.4 \text { (glacier formed lake) }{ }^{18}[1]\end{array}$ & $\begin{array}{l}103-147^{4}[3] \\
727-812^{5}[2]\end{array}$ & $291-1468^{5}$ & $109.0^{10}$ \\
\hline $\mathrm{Ni}\left[\mu \mathrm{g} \mathrm{L}^{1}\right]$ & $0.1^{14}$ & $2.4^{13}$ & $\begin{array}{l}0.1-71.1^{4} \\
0-20.5^{20}\end{array}$ & $0-117$ (contaminated lakes) $)^{29}[15]$ & $\begin{array}{l}0.7-6.4^{3}[5] \\
1.2-7.2^{4}[3] \\
4-13^{5}[2]\end{array}$ & $>0.2-80^{4}$ & $0.1-0.7^{2}$ \\
\hline $\mathrm{NO}_{3}\left[\mathrm{mg} \mathrm{L}^{1}\right]$ & $\begin{array}{l}0.3-3.9^{1} \\
0-0.8 \mathrm{mg} \mathrm{L}-1(\mathrm{~N})^{15} \\
0-2^{16}\end{array}$ & $\begin{array}{l}0.6-31.0 \text { (pristine rivers) }^{7} \\
0.6-372 \text { (present-day rivers) }^{7} \\
2.1-2.5^{12} \text { (European rivers) }^{-}\end{array}$ & $\begin{array}{l}0.1-12.4^{1} \\
0.1-58.1^{4} \\
17-21^{12}\end{array}$ & $\begin{array}{l}0-0.7 \text { (alpine lakes) })^{25}[28] \\
0.02-1.8 \text { (nutrient rich lakes; total } \mathrm{N} \text { : } \\
0.76-3.02)^{40}[37] \\
0.03-3.6 \text { (annual average; man-made/peat } \\
\text { lakes) })^{42}[39]\end{array}$ & $\begin{array}{l}<1.25^{5}[2] \\
0.1-6.8 \text { (infiltrated river water })^{4}[1] \\
1.0-4.3 \text { (groundwater fed only) }{ }^{4}[2] \\
1.5-18.0(\text { approximate range })^{3}[5] \\
9.35^{32}[1]\end{array}$ & $<1.25-56^{5}$ & $0-2.7(\text { mean } 1.8)^{2}$ \\
\hline $\mathrm{PO}_{4}\left[\mathrm{mg} \mathrm{L}^{1}\right]$ & $0.005-0.41^{37}$ & $\begin{array}{l}0.03-0.9 \text { (median } 0.5 \text { ) pristine - human } \\
\text { impacted up to } 15.8^{7}\end{array}$ & $0.02-2.1^{4}$ & $\begin{array}{l}0.025-0.03^{12} \text { [rev] } \\
0.004-1.24 \text { (soluble reactive P) } 0.055-1.59 \\
(\text { Total P) })^{40}[37] \\
0.031-0.49 \text { (annual average total P; } \\
\text { man-made/peat lakes }{ }^{42}[39]\end{array}$ & $\begin{array}{l}0.01-0.03\left(\mathrm{PO}_{4}\right)^{4}[3] \\
0.5-0.6(\text { total P })^{5}[2]\end{array}$ & $0.4-4.1^{5}$ & $\begin{array}{l}0.01-0.07 \text { (mean, open } \\
\text { ocean })^{19}\end{array}$ \\
\hline $\mathrm{SO}_{4}\left[\mathrm{mg} \mathrm{L}^{1}\right]$ & $\begin{array}{l}0.4-8.4^{1} \\
0-2.5^{16}\end{array}$ & $33-239^{5}$ & $\begin{array}{l}1.0-480.3^{1} \\
0.2-105.8^{4}\end{array}$ & $1.8-45.4^{11}[>23 \mathrm{rev}]$ & $\begin{array}{l}16.1-78.5^{4}[3] \\
218-290^{5}[2]\end{array}$ & $231-2183^{5}$ & $2743^{10}$ \\
\hline $\operatorname{Zn}\left[\mu \mathrm{LL}^{1}\right]$ & $6.3^{14}$ & $10.3^{13}$ & $8.3-1607.8^{4}$ & $0.6-3.9^{11}[>23 \mathrm{rev}]$ & $\begin{array}{l}4.7-16.4^{4}[3] \\
<0.1-13.3^{3}[5]\end{array}$ & $30-463^{4}$ & $0.003-0.6^{2}$ \\
\hline $\begin{array}{l}\delta^{2} \mathrm{H}(\% \text { vs } \\
\quad \text { VSMOW) }\end{array}$ & $\begin{array}{l}46.78^{4} \\
56.00^{34} \\
114.8 \min -20.4 \max ^{36}\end{array}$ & $\begin{array}{l}44.56^{4} \\
52.04^{33}\end{array}$ & $47.44^{4^{*}}$ & $\begin{array}{l}97.04^{35}[100 \text { rev }] \\
88.44 \text { (peri alpine lake })^{36}[1]\end{array}$ & $\begin{array}{l}31.64^{4 * *}[2] \\
35.65^{5}[2]\end{array}$ & $38.19^{33^{*}}$ & $\begin{array}{l}\text { 0.00 SMOW } \\
18.20 \text { (coastal Adriatic Sea) }^{33}\end{array}$ \\
\hline $\begin{array}{l}\delta^{18} \mathrm{O}(\% \text { vs } \\
\text { VSMOW) }\end{array}$ & $\begin{array}{l}7.00^{4} \\
-8.2^{34} \\
-15.4 \min -3.2 \max ^{36}\end{array}$ & $\begin{array}{r}6.00^{4} \\
-8.16^{33}\end{array}$ & $7.26^{4^{*}}$ & $\begin{array}{l}11.45^{35}[100 \text { rev }] \\
12.31 \text { (peri alpine lake })^{36}[1]\end{array}$ & $\begin{array}{l}4.25^{4^{* *}}[2] \\
4.86^{5}[2] \\
7.5 \text { to } 0.5^{43}[9]\end{array}$ & $5.54^{33^{*}}$ & $\begin{array}{l}0.00 \\
2.77 \text { (coastal Adriatic Sea })^{33}\end{array}$ \\
\hline
\end{tabular}

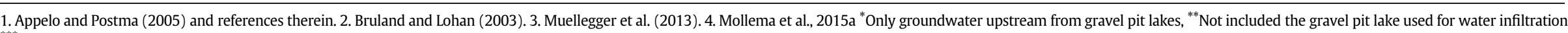

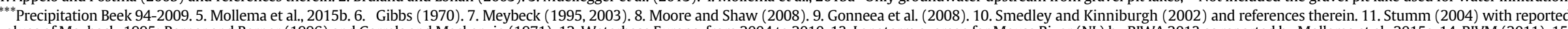

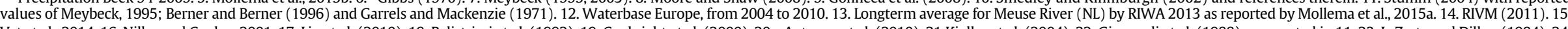

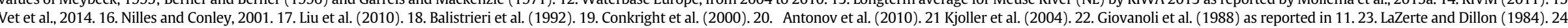

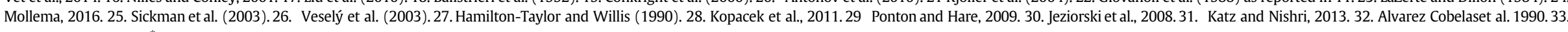

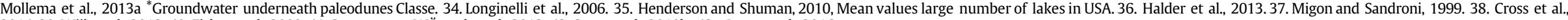
2014. 39. Wiik et al., 2013. 40. Fisher et al., 2009. 41. Sommaruga-WÖgrath et al., 2013. 42. Sayer et al., 2010b; 43. Jones et al., 2016. 


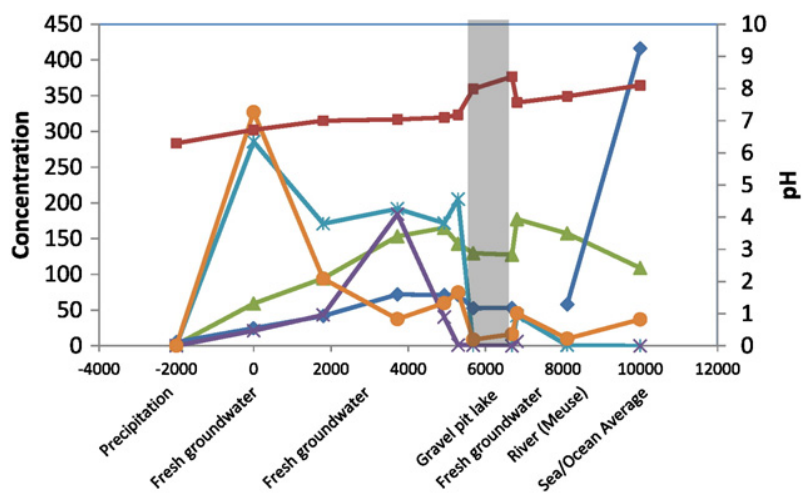

Distance along profile $[\mathrm{m}]$ / Increasing travel time
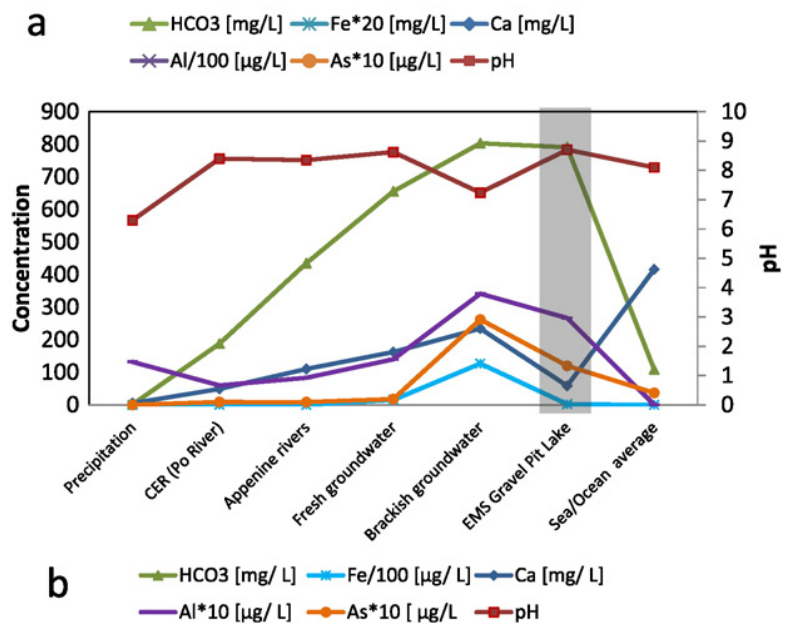

Fig. 5. Examples of relative enrichment and depletion in selected dissolved elements and components and $\mathrm{pH}$ in gravel pit lakes. Precipitation and seawater data are taken from the literature and ground and surface water data are averages over multiple samples. See Table 2 and Mollema et al. (2015a, b) for original data. Read from left to right along the horizontal axis. Precipitation contains very little amounts of anions, cations and dissolved metals. River water usually has a higher concentration of solutes; strong enrichment occurs in groundwater due to water-rock interactions especially in coastal zones. When groundwater exfiltrates into surface water bodies such as (gravel) pit lakes, rivers or sea, strong changes in concentration in certain elements occur. A. Example from a freshwater fluvial system (The Netherlands, where freshwater flows through the gravel pit lake (data from Mollema et al., 2013a) and from Appelo and Postma (2005) and references therein, Seawater data from Bruland and Lohan (2003); Meybeck (1995, 2003), Precipitation data from RIVM (2011); Liu et al. (2010), see Table 2. The horizontal axis represents the realistic distance along the profile except for the location of precipitation and seawater. B. Example from a coastal brackish-saline groundwater and gravel pit lake system (Italy).

higher than 1 meq L $\mathrm{L}^{-1}$ or $\mathrm{HCO}_{3}$ of $61 \mathrm{mg} \mathrm{L}^{-1}$; Marcé et al., 2015). The exact relation between the particular source of $\mathrm{C}$ input (DIC, organic car

bon (OC), primary production, etc.) and its fate in lakes in general and gravel pit lakes in particular are still unclear (Hanson et al., 2015).

The gravel pit lakes of this review have a pH that varies between 7.2

and 10.4 (Table 2) and the $\mathrm{HCO}_{3}$ concentrations range from 103 to $147 \mathrm{mg} \mathrm{L}^{-1}$ in freshwater gravel pit lakes and from 727 to

$812 \mathrm{mg} \mathrm{L}^{-1}$ in saline gravel pit lakes (Table 2 and Fig. 6). The alkalinity exceeds the threshold of 1 meq $\mathrm{L}^{-1}$ (Marcé et al., 2015) suggesting that

the alkalinity is caused by weathering and leaching of carbonates in the

catchment rather than in situ production by photosynthesis.

In coastal zones, saline lakes surrounded by a brackish aquifer are affected also by cation exchange as the infiltration of saline water in a fresh aquifer or freshwater into a brackish aquifer promotes the ex change of cations including $\mathrm{Ca}$ and $\mathrm{Na}$ (e.g. Andersen et al., 2005; Appelo and Postma, 2005).

The Ca cycle is related to the carbon cycle in biochemical processes as $\mathrm{CaCO}_{3}$ is incorporated into the skeleton or shell of many organisms.
Previous studies on other types of lakes showed that calcite precipitation occurs in pulses during phases of high primary production of phytoplankton between May and October (peri alpine Lake Zurich: Kelts and Hsu, 1978; Naeher et al., 2013; Sigg et al., 1987; Marl lakes: Wiik et al., 2013) also on macrophytes (Bloesch, 2004). Observed dissolved Ca concentration in gravel pit lakes ranges between 29 and $56 \mathrm{mg} \mathrm{L}^{-1}$ in freshwater and between 57 and $136 \mathrm{mg} \mathrm{L}^{-1}$ in saline gravel pit lakes (Table 2). The Ca depletion of gravel pit lake water with respect to upstream groundwater (Fig. 5; Mollema et al., 2014, Mollema et al., 2015a, b; Muellegger et al., 2013) indicates that $\mathrm{CaCO}_{3}$ precipitation on the lake bottom plays a role in gravel pit lakes in a freshwater fluvial setting as well as in a brackish coastal setting (Fig. 5). Gravel pit lakes are potentially very efficient in $\mathrm{CaCO}_{3}$ precipitation since high epilimnic water temperatures and high $\mathrm{pH}$ in combination with high primary pro duction and intensive $\mathrm{CO}_{2}$ assimilation leads to reduced $\mathrm{CaCO}_{3}$ solubility (Walpersdorf et al., 2004). A very important side effect of natural calcite precipitation is the removal of particulate and dissolved $\mathrm{P}$ from the water column as well as metals as Fe and Mn (Walpersdorf et al., 2004; see Section 4.4).

\subsection{Metal and trace element cycling}

Introducing gravel pit lakes where previously there was an aquifer changes the metal budget of a catchment (Fig. 9). Redox reactions occur generally in all types of aquifer sediments (Appelo and Postma, 2005) including those upstream and downstream of gravel pit lakes (e.g. Mollema et al., 2015a, b). The redox reactions are triggered for ex ample by natural acidification of the soil or anthropic acidification due to atmospheric acid deposition, fluctuating water tables and with the in troduction of acid due to mining activities or fertilizers (Gandy and Younger, 2008; Marques et al. 2008; Mollema et al., 2015a; Weiske et al., 2013). The excavation of the gravel pit lakes themselves or nearby water ways can be the cause for water table fluctuations that trigger redox reactions (Mollema et al., 2015a). Well known redox reactions are denitrification mediated by pyrite or other Fe compounds (Appelo and Postma, 2005; Choi et al., 2011 and references in both). Py riteoxidation may also occur by nitrate or oxygen rich groundwater (Appelo and Postma, 2005). This reaction produces $\mathrm{H}^{+}$which may then contributes to the nitrate reduction of pyrite and ferrous iron (Appelo and Postma, 2005). Pyrite normally contains trace elements (As, Cobalt (Co), Nickel (Ni), $\mathrm{Zn}$ ) that can be released upon pyrite oxida tion. As a result of the redox reactions in the aquifer, Fe, As, $\mathrm{Ni}$ and $\mathrm{Zn}$ concentrations (among others) can be very high in fresh and brackish groundwater upstream from gravel pit lakes as observed so far in Dutch and Italian case studies (Fig. 6; Table 2; Mollema et al., 2015a, b). Arsenic remains more in solution in groundwater with a high $\mathrm{pH}$ while on the contrary $\mathrm{Co}, \mathrm{Ni}$ and $\mathrm{Zn}$ remain in solution in water with a lower $\mathrm{pH}(<6)$. When metals dissolved in (acid) groundwater flow into a gravel pit lake, they come into contact with less acidic and usually better oxygenated water. These are conditions under which $\mathrm{Fe}$, and Manganese (Mn) hydr(oxides) precipitate, binding also to organic matter, $\mathrm{P}$ and Ca removing these elements (temporarily) from the water column. $\mathrm{Zn}, \mathrm{Cu}$ and $\mathrm{Ni}$ and other metals may adsorb on and co-precipitate with Fe and Mn oxyhydroxides eliminating also those elements from the lake water column (Appelo and Postma, 2005; Tessier et al., $1985)$. The metals precipitated to the bottom of natural lakes are known to participate in cycling redox processes (e.g. Naeher et al., 2013 and Stumm, 2004 and references in both). Our literature review (Table 2) reveals dissolved Al concentration up to $8094 \mu \mathrm{g} \mathrm{L} \mathrm{L}^{-1}$ in acid soils and the highest concentrations in natural lakes is up to $1349 \mu \mathrm{g} \mathrm{L}{ }^{-1}$ whereas Al concentrations observed so far in gravel pit lakes do not exceed 30 $\mu \mathrm{g} \mathrm{L}^{-1}$. Remobilization of (heavy) metals in floodplains may also contribute to metal deposition in gravel pit lakes, especially downstream of mines (Du Laing et al., 2009; Zhao and Marriott, 2013). 

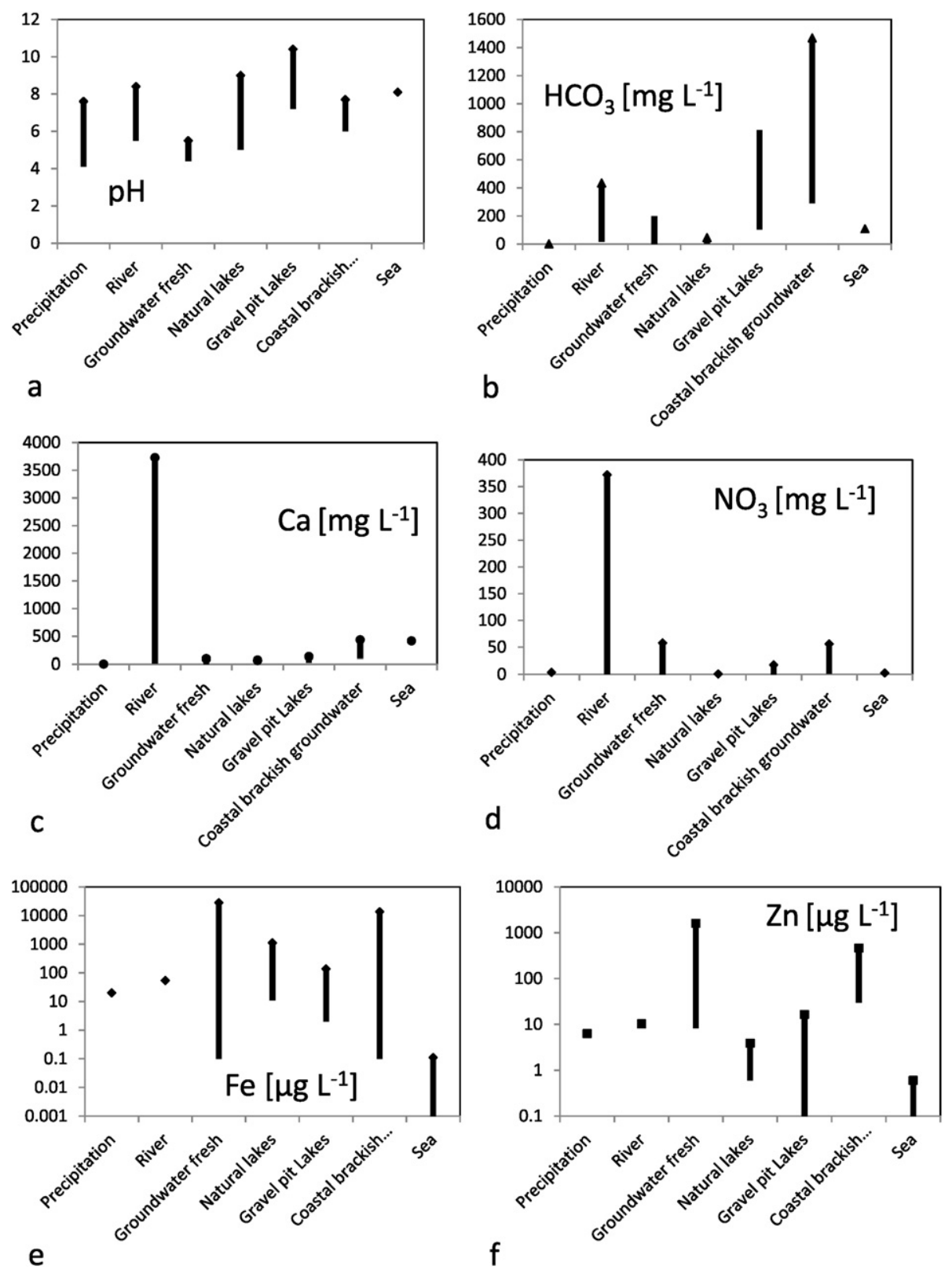

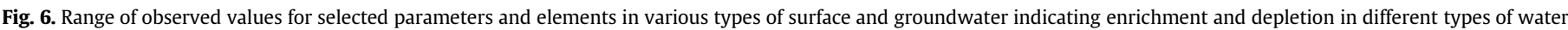

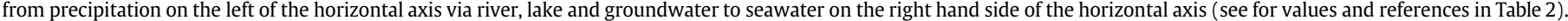
Symbols indicate maximum observed value as documented in the reviewed literature. a. pH, b. $\mathrm{HCO}_{3}$, c. Ca, d. $\mathrm{NO}_{3}$ e. Fe f. $\mathrm{Zn}$.

In some cases, the metal concentration in lake bottom sediments may exceed legal norms (Mollema et al., 2015a). This could become a practical problem as cleaning lakes of their sediments is not an easy en deavor and the very process of cleaning may reduce water quality. In stead high dissolved metal concentration in lake water may occur if there is a lack of binding material such as organic matter or $\mathrm{H}_{2} \mathrm{~S}$, and $\mathrm{CaCO}_{3}$ (Walpersdorf et al., 2004) that help fix metals to lake bottom sed iments. The sulfide ion has a strong affinity for many heavy metals and so will precipitate as metal sulfides (Manahan, 2013).

\section{Ecological functioning}

The creation of gravel pit lakes typically increases the diversity of aquatic habitats in a catchment (Fig. 10). Some species of flora and fauna do thrive in groundwater (e.g. Danielopol et al., 2000) but gravel pit lakes, especially in an urban setting, increase biodiversity (e.g. Santoul et al., 2009). The direct interaction of a lake surface with the atmosphere and the infiltration of sunlight make it possible for primary producers (e.g. algae) to convert inorganic carbon from atmospheric $\mathrm{CO}_{2}$ or from dissolved $\mathrm{HCO}_{3}$ into organic carbon through photosynthe sis, forming the base of a large food web. This section gives a brief over view of the types of biological communities that are observed in lakes in general and in gravel pit lakes in particular with emphasis on the inter action with the chemical cycles described in Section 4. For a more de tailed description of species and biological functioning, the reader is referred to the bibliography.

Phytoplankton are single celled organisms of lakes, streams and oceans that make their own food from sunlight through photosynthesis. They include green algae, diatoms, cyanobacteria, dinoflagellates and coccolithophores (Padisák, 2004). Besides inorganic carbon, phyto plankton needs at least 20 other chemical elements to survive of which $\mathrm{P}, \mathrm{N}$ Si and Fe are thought to be the most important. Generally, the lack of one of these elements determines the growth of phytoplank ton (Padisák, 2004; Reynolds, 2004; Weilhartner et al., 2012). The 


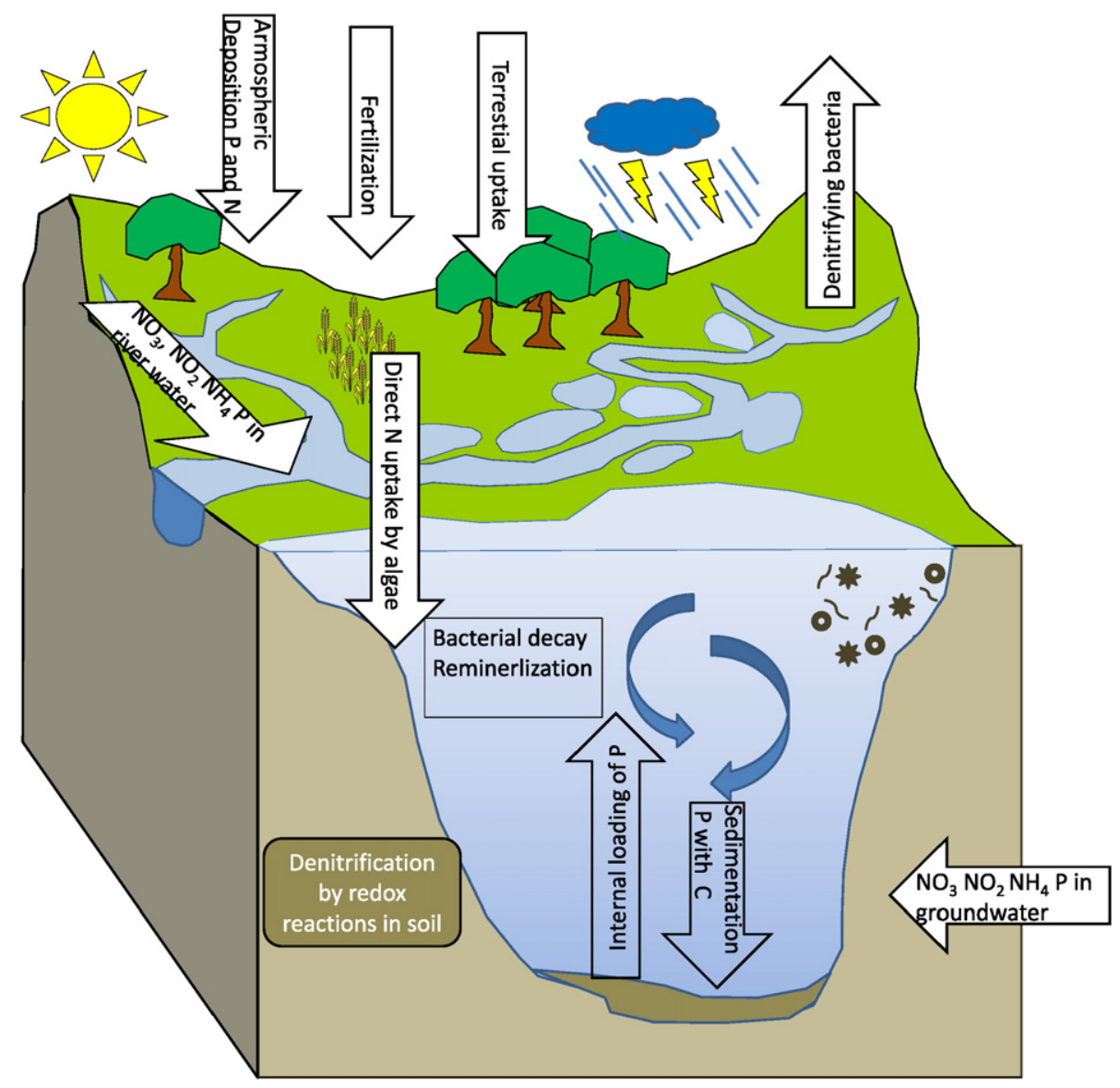

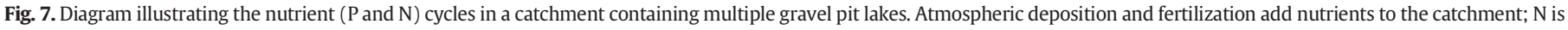
fixed by vegetation on land and algae in the surface water. P becomes part of lake sediments in chemical compounds that include organic matter (plankton). Adapted from Tranvik et al. (2009).

gravel pit lakes reviewed here are $\mathrm{HCO}_{3}$ rich (Table 2), so there will be probably no lack of inorganic carbon dissolved in water. As discussed in paragraph 4.2, P, N, Si and Fe may come in with river water in connected gravel pit lakes (Cross et al., 2014) or with groundwater into isolated gravel pit lakes (Weilhartner et al., 2012: Mollema et al., 2015a, b), so there is unlikely to be a shortage of these elements in gravel pit lakes. The life cycle of phytoplankton in gravel pit lakes contributes to denitri fication of lake water which may improve water quality (Fig. 10; Helmer and Labroue, 1993; Muellegger et al., 2012; Weilhartner et al., 2012). Phytoplankton species richness in gravel pit lakes may be large (Arauzo et al., 1996; Cross, 2009; Garnier and Billen, 1994; Hindak and Hindakova, 2003; Padisák et al., 2003; Sayer and Roberts, 2001; Tremel, 1996) but varies from season to season and with water salinity (Chapman et al., 1997) and the input of river water during floods (Cross, 2009). Cyanobacteria that can take up $\mathrm{N}_{2}$ directly from the atmosphere also occur in gravel pit lakes (Cross, 2009; Hindak and Hindakova, 2003; Rojo and Alvarez Cobelas, 1994). Microbial (bacterial) and fungal plank ton (mycoplankton) live on detritus and play an important role in re mineralising organic material down the water column and in nutrient cycling (Weisse, 2004). Zooplankton, also called grazers or herbivores, includes small protozoans or metazoans that feed mostly on phyto plankton, bacteria and detritus. In the spring, there is typically a strong increase in phytoplankton in temperate regions that leads to an increase in the zooplankton biomass and this is followed in many instances by a depletion of edible phytoplankton and a significant clearing of the water, often called 'clear water phase' (Lewis, 1980; Sommer et al., 1986). Aquatic macrophytes (water plants which can be viewed with out a microscope) include vascular plants, mosses and the larger fila mentous algae (e.g. Pokorný and Květ, 2004). They provide habitat and food for zooplankton and zoobenthos, concentrate nutrients, and release oxygen during photosynthesis (Fig. 10). The rooting systems of macrophytes provide access to nutrients in the underlying littoral sedi ment and its interstitial water (e.g. Mo, Fe). Macrophytes may concen trate certain elements like $\mathrm{P}, \mathrm{K}$ and $\mathrm{Mn}$, which may reach 1000 and over 10,000 fold higher concentrations than the surrounding water (Dykyjova et al., 1998). They also play a role in the Ca cycle as photosyn thetic uptake of free carbon dioxide and bicarbonate often leads to pre cipitation of calcium carbonate on the surface of water macrophytes (Pokorný and Květ, 2004) reducing thus the dissolved Ca concentration in lake water. Macrophytes enhance the rate of nutrient cycling as veg etated sediments showed significantly higher rates of $N$ cycling than bare sediments (Vila Costa et al., 2016). Last but not least macrophytes together with phytoplankton and periphyton are also important deter minants of the oxygen regime of the lake.

In older gravel pit lakes, the slopes may be too steep for all habitat types to be present. For example, the macrophyte zone (Fig. 10) may be very small or non existent due to the lack of a shallow lake edge. The growth of submerged plants is related strongly to light availability, hence the importance of lake bed topography. On the other hand, in shallow gravel pit lakes the macrophyte zone may be relatively large while the pelagic zone may be small or missing. The macrophyte com munity may also change over time after extraction of gravel stopped (Lambert Servien et al., 2006). The topography of the lake bottom influ ences not only the macrophyte community but also other parts of the food chain as shown by Jeppesen et al. (1997) who found an inverse re lationship between the relative contribution to secondary production of zoobenthos and lake depth. In smaller lakes the relative influence of the watershed increases with more rapid hydrological renewal, larger 


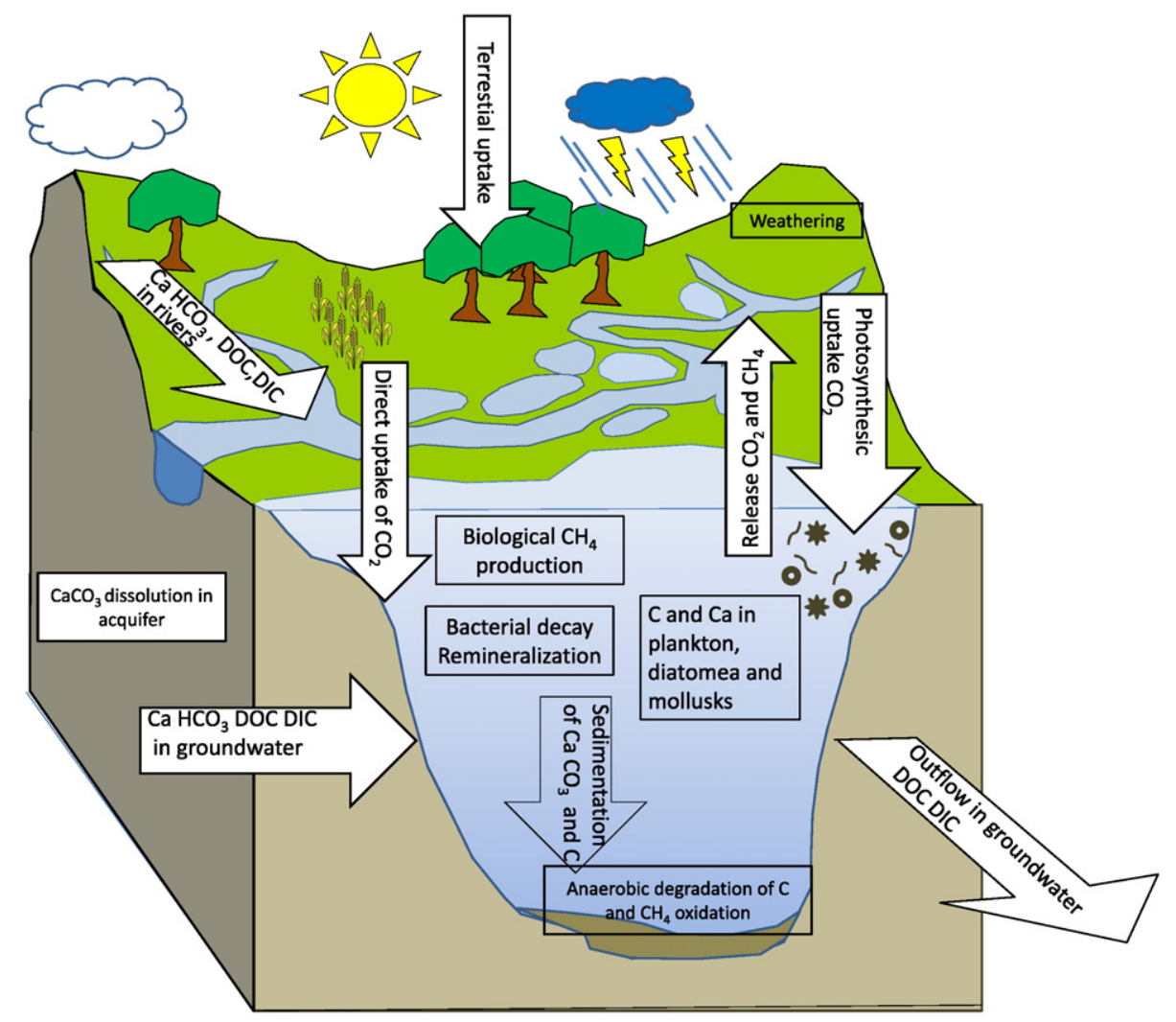

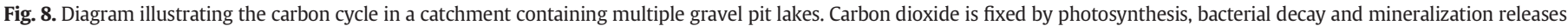

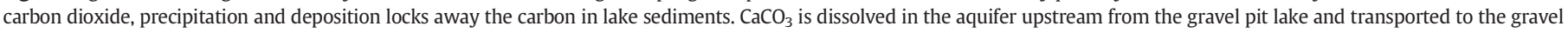
pit lakes. See text for further explanation.

nutrient imports and enhanced cycling. Most gravel pit lakes are in a suburban setting influenced by agricultural activities and as a consequence are eutrophic to hypertrophic with possibly algal blooms (Alvarez Cobelas et al., 1992; Cross et al. 2014). Deeper gravel pit lakes (Mollema et al., 2015a) or brackish gravel pit lakes (Chapman et al., 1997; Mollema et al., 2015b) may not have this problem so much. In coastal gravel pit lakes the unnatural salinity range $\left(512 \mathrm{~g} \mathrm{~L}^{-1}\right)$ may limit species richness (Mollema et al., 2015a, b; Bleich et al., 2011). Fish and birds inhabit gravel pit lakes either naturally or artificially in troduced (e.g. Giles, 1994; Santoul et al., 2009), and it is the subtle interaction between all levels of the food web, the influx of nutrients and other chemical elements as well as the climate that determine the sta bility and quality of gravel pit lake water (see Section 7).

\section{Effects of climate change on hydrological aspects of gravel pit lakes}

The changes foreseen by the IPCC (2013) due to anthropogenic emissions of greenhouse gasses include increasing air temperature over the time span of decades as well as changes in the seasonal variability of periods of droughts and rainstorms and sea level rise. In this section the influence of these changes on the hydrology of gravel pit lakes is discussed.

\subsection{Changes in $E$ and $E T_{a}$}

We use data from two case studies to compare the water budget of gravel pit lakes. One case is the Meuse Lakes (The Netherlands) with a temperate climate. The Meuse Lakes or Maasplassen in Dutch are the collective name for 71 lakes that formed during gravel and sand excavation along the river Meuse in the southern Netherlands and North Belgium (Electronic supplement A). Today, they are mostly used for recreation except one that is used for drinking water production (Mollema et al., 2015a). The total surface area of the 71 lakes between Swalmen (Nether lands) and Maaseik (Belgium) is $18 \mathrm{~km}^{2}$. For the Meuse Lakes we used the historical climate data of Maastricht (Netherlands, average 1981 2010) and future climate scenarios for the year 2050 and for the year 2085 as published by KNMI (2014), see Electronic supplement B for details.

The other study area is along the Adriatic Coast, (North Italy) with a Mediterranean Climate.

The brackish saline coastal gravel pit lakes near Ravenna, Italy occupy more than $6 \%$ of the surface in this catchment and are used mostly for recreation (Mollema et al., 2015b). We used the historical climate data for Ravenna for the reference period 19892008 from Mollema et al. (2012), and IPCC (2013) scenarios for the period 2046 2065, and for the period 20812100 (Electronic supplement C). To quantify the effect of these gravel pit lakes on the water budget of their respective catch ments, we calculated the surface water E with the Penman Monteith equation as described in Maidment (1992) under current climate and future climate scenarios. We compared $\mathrm{E}$ with $\mathrm{ET}_{\mathrm{a}}$ of a similar surface covered with grassland, under the same climatic conditions, calculated with Cropwat (Allen et al., 1998; Smith, 1992), a model based on the Penman Monteith (1948) equation and a soil water budget. The Cropwat model takes into account the difference between available water in the soil column and potential grass evapotranspiration, calculating thus the actual grass evapotranspiration.

The seasonal accumulative $\mathrm{E}$ and $\mathrm{ET}_{\mathrm{a}}$ are shown in Fig. 11a (Meuse Lakes, NL) and Fig. 11c (Ravenna, It) while Fig. 11b and d show the precipitation for the reference period and future climate scenarios for respectively the Dutch and Italian site.

The calculations show that $\mathrm{E}$ of both the Dutch and the Italian gravel pit lakes will increase under all climate scenarios. The largest increase for the Dutch lakes is predicted under the Wh scenario for the year 2085: $38 \mathrm{~mm}$ (10\%) in spring and $96 \mathrm{~mm}$ (17\%) in summer with respect 


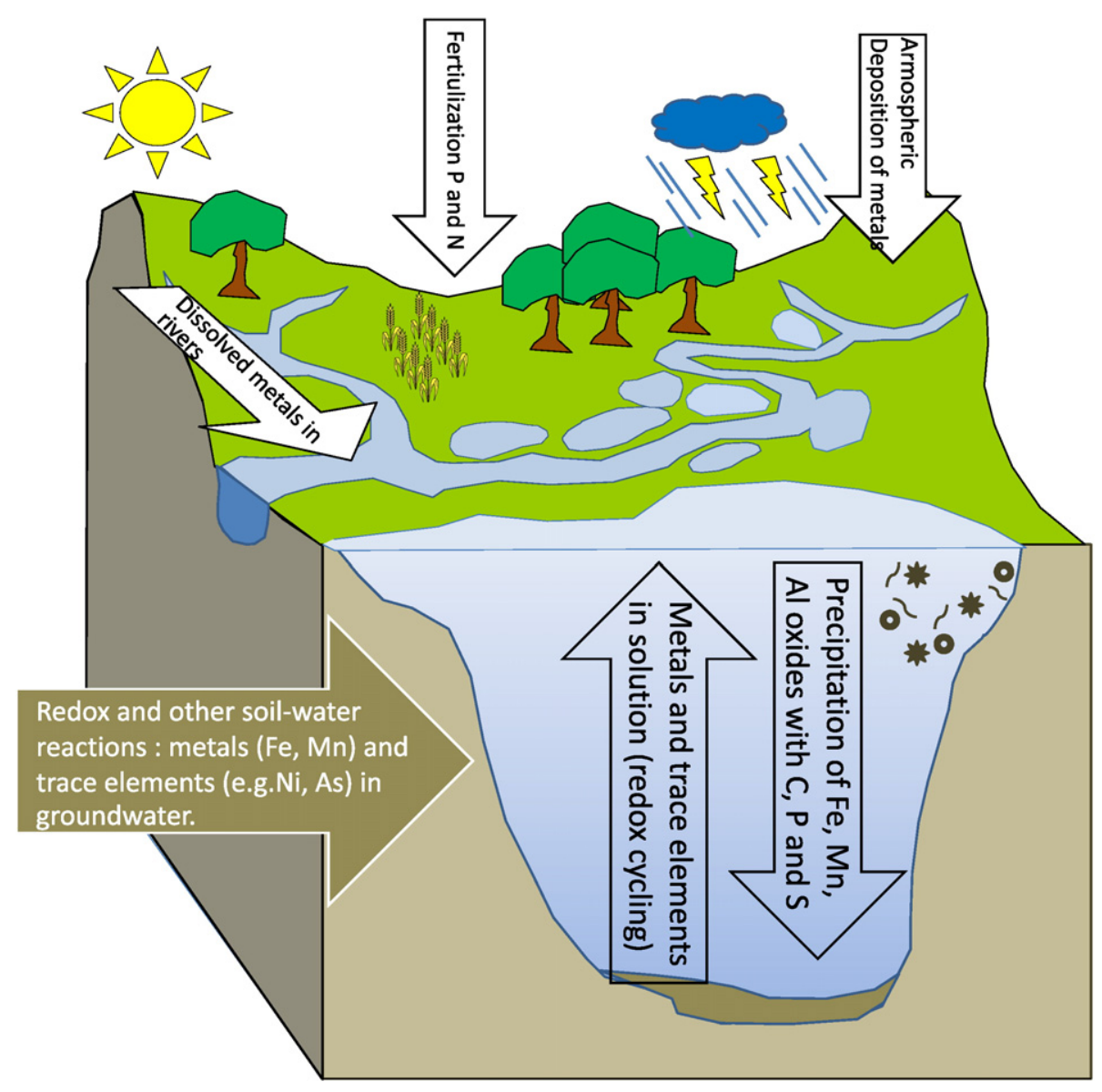

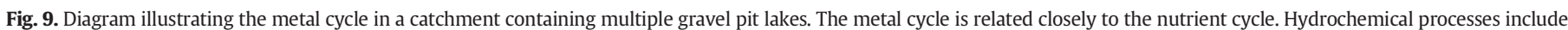

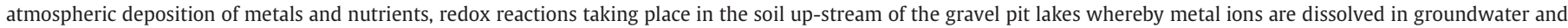

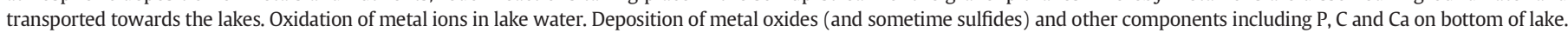

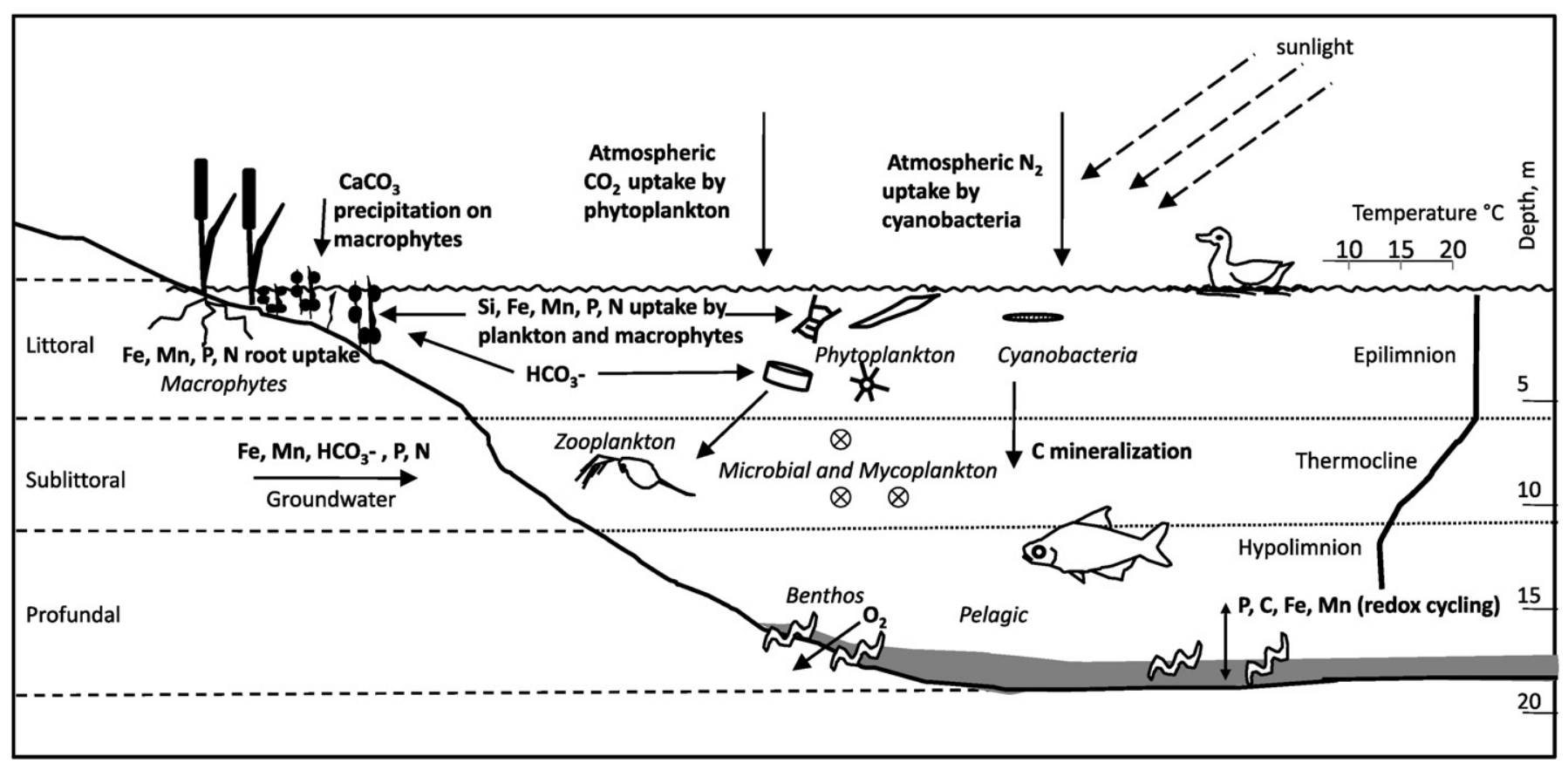

Fig. 10. Ecological communities in a gravel pit lake and interaction with the chemical cycles. 
to the period 19812010 (Fig. 11a). The E rate in the Mediterranean climate is already high but there is an increase to be expected by the end of the century: in spring by $35 \mathrm{~mm}$ (8\%) and in summer by $56 \mathrm{~mm}(14 \%)$. The increase is caused by the increase in maximum and minimum tem perature and solar radiation and in the Netherlands, also by a decrease of the relative humidity (KNMI, 2014). $\mathrm{ET}_{\mathrm{a}}$ near the Dutch gravel pit lakes during spring will increase in 2050 by $6 \mathrm{~mm}$ and in 2085 by 26 $\mathrm{mm}$ under the Wh scenario. Summer $\mathrm{ET}_{\mathrm{a}}$ will increase in 2050 by 15 $\mathrm{mm}(8 \%)$ under the Gl scenario but will decrease by $50 \mathrm{~mm}(28 \%)$ under the 2085 Wh scenario (Fig. 11a). The decrease can be explained by the fact that precipitation under the Wh scenario will decrease con siderably during the growth season, so that there will be less soil mois ture available for transpiration even though the sun will provide enough energy.

$\mathrm{ET}_{\mathrm{a}}$ in Ravenna will increase in summer but will decrease in spring since there will be less precipitation in that season (Fig. 12). The histor ical $\mathrm{ET}_{\mathrm{a}}$ for Ravenna is similar to the future $\mathrm{ET}_{\mathrm{a}}$ rate for the Netherlands by the end of the century (Compare Fig. 11a and c): $\mathrm{ET}_{\mathrm{a}}$ is higher in spring than in summer because there is more soil moisture available.

In summary, under these climate scenarios, catchments with gravel pit lakes in a temperate and Mediterranean climate, where evaporated gravel pit lake water is replaced immediately with inflowing ground or river water, will lose more freshwater due to $\mathrm{E}$ than a catchment without gravel pit lakes would lose due to $\mathrm{ET}_{\mathrm{a}}$. This confirms a world wide trend of increase in water withdrawal due to evaporation from ar tificial lakes and reservoirs: from the year 1900 to 2010 evaporation from artificial lakes and reservoirs increased from practically 0 to 333 $\mathrm{km}^{3}$ year $^{-1}$ and now amounts to $8 \%$ of total global water withdraw al (FAO, 2015). The increasing numbers of gravel pit lakes excavated in this period contributes to this process.

The Meuse Lakes cover a total surface area of $18 \mathrm{~km}^{2}$ (Electronic supplement A). Much more water $\left(12.4 \times 10^{6} \mathrm{~m}^{3}\right.$ by 2050 and $15.3 \times 10^{6} \mathrm{~m}^{3}$ by 2085 ) will evaporate during future summers than if the catchment had consisted of the original grassland. A change of land use from forest to grassland is often incorporated in basin wide
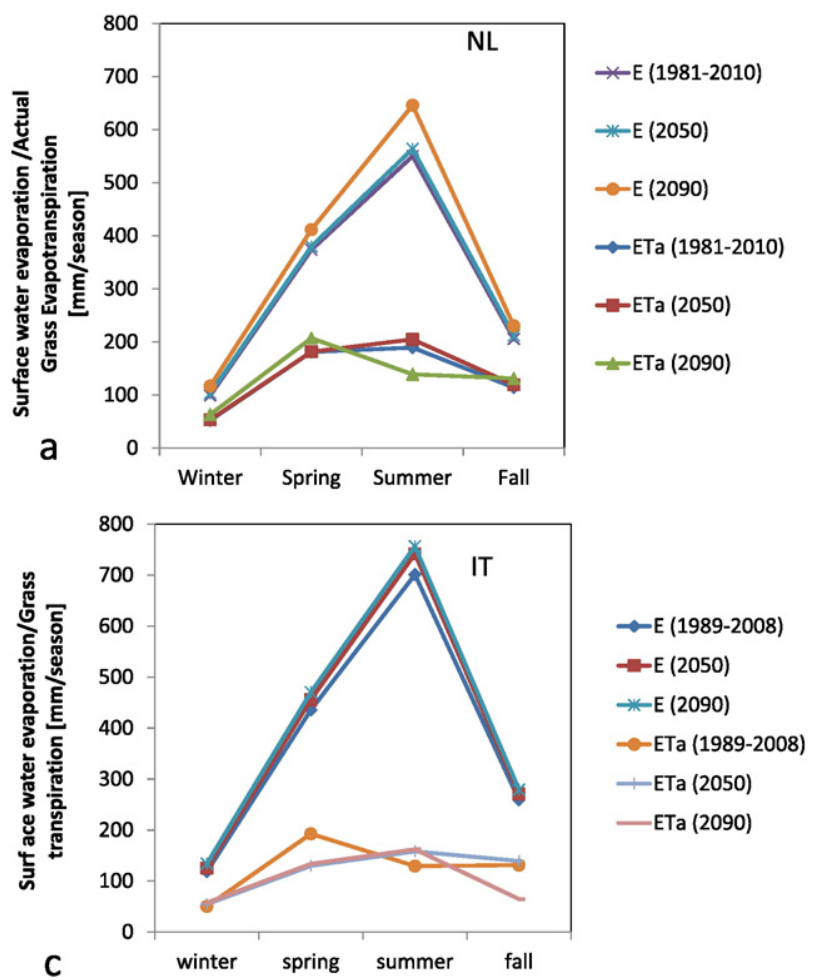

water balance models (e.g. Ward et al., 2008) but similarly the change from grassland to surface water (i.e. gravel pit lakes) should be taken into account or these models may underestimate the amount of water leaving the watershed by $\mathrm{E}$ and $\mathrm{ET}_{\mathrm{a}}$.

\subsection{Hydrological and meteorological extremes}

Besides the more or less gradual changes in average climatic param eters, also more sudden changes will affect gravel pit lakes such as droughts and floods caused by concentration of storms in shorter pe riods foreseen by IPCC (2013). Cross et al. (2014) found that under such extreme hydrological conditions British gravel pit lakes connected to the River Erewash were affected differently than those isolated from the river. In particular, the isolated lakes had longer water residence (re tention) times, smaller influx of nutrients and higher extent of internal nutrient recycling than the lakes connected to the river (Cross et al., 2014; see Section 7.2 for the ecological consequences of these process es). During droughts or floods, lake levels could fall or rise but whether this will happen depends on the changes in the river flow for lakes that are fed by river water and on groundwater levels for flow through lakes. Changes in natural or artificial drainage required by climate and land use change will affect the water budgets of gravel pit lakes. For example in a low lying coastal plain setting, a rising sea level would require en hanced drainage of the low lying land which would augment the ground water flow into the gravel pit lakes (Mollema et al., 2015b). If the $\mathrm{Cl}$ concentration of ground water is lower than that of lake water, the resulting $\mathrm{Cl}$ concentration of the lake will decrease under enhanced drainage while increasing evaporation will instead increase $\mathrm{Cl}$ concentration. Periods of droughts and rainstorms however could dilute or concentrate lake water in a short period.

\subsection{Lake and groundwater temperature}

Shallow (2 to $3 \mathrm{~m}$ ) gravel pit lakes typically show a weak temperature stratification only during summer (Cross, 2009). However, gravel
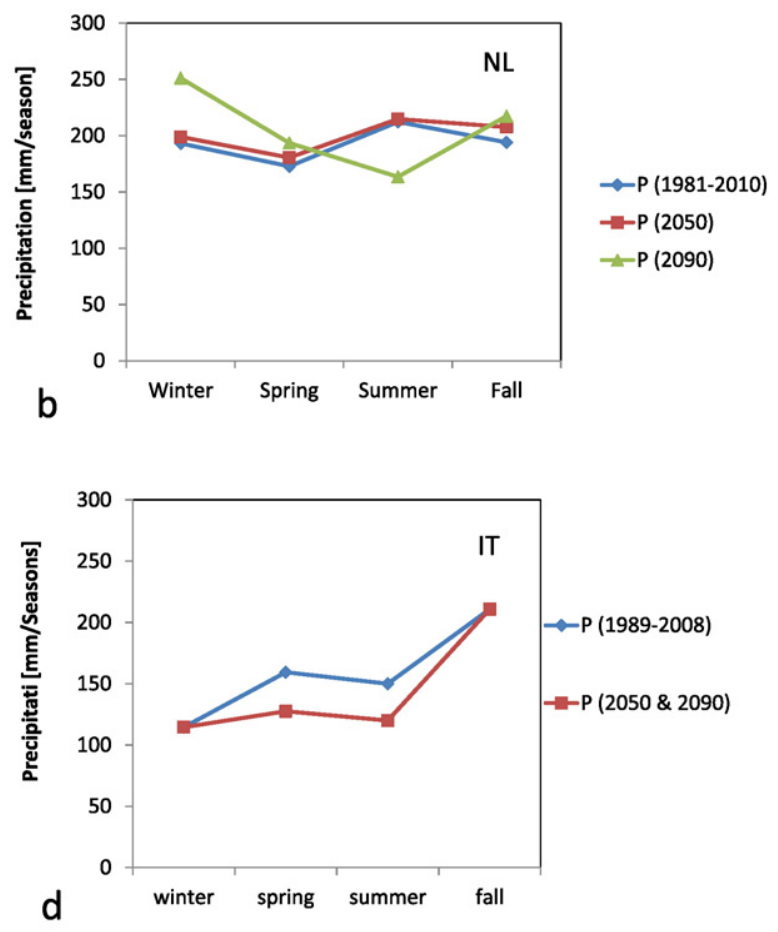

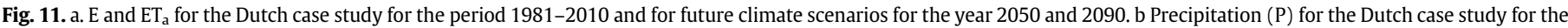

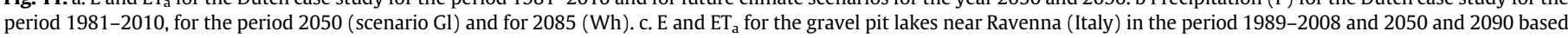
on scenarios by IPCC (2013). d. P for Ravenna (Italy) for the period 1989-2008 and for 2050 and 2090 based on scenarios by IPCC (2013). 


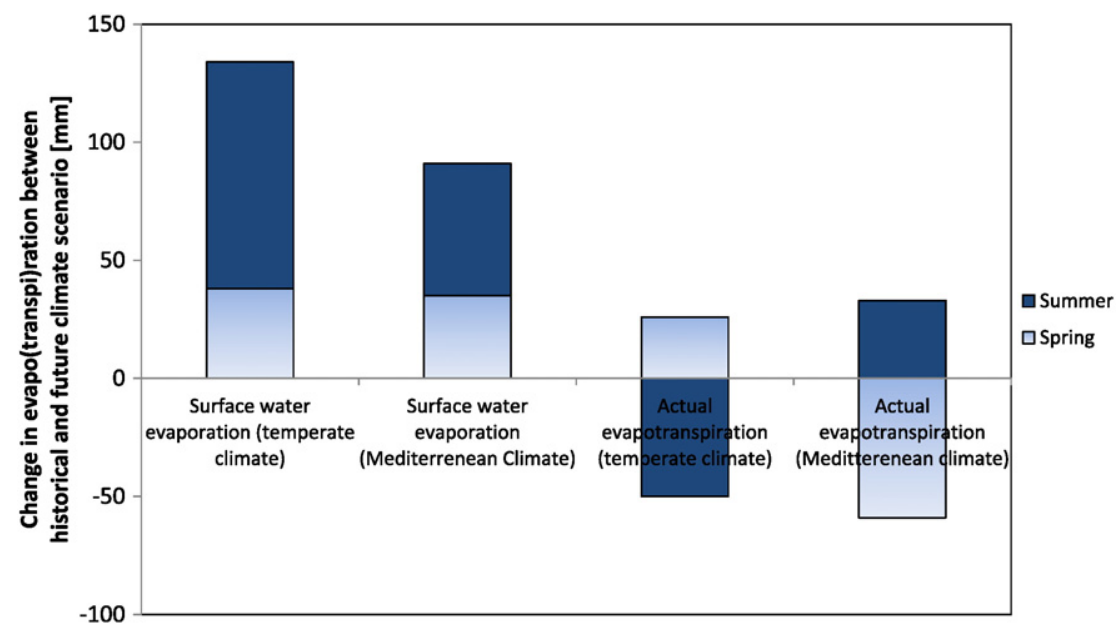

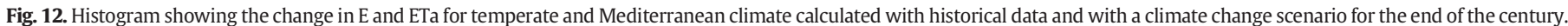
A positive change means that the evaporation rate will increase.

pit lakes, if they are deep enough, may be thermally stratified with a dis tinct epilimnion, thermocline and hypolimnion as observed in the Boschmolen lake (The Netherlands) that is 30 to $40 \mathrm{~m}$ deep (Figs. 10, 13), similar to natural lakes (Imboden and Wuest, 1995; Imboden, 2004). De stratification by air pumps may occur in gravel pit lakes used for drinking water production (Mollema et al., 2015a).

As far as we know, no observations on changing water temperatures over time for gravel pit lakes have been published but Scheffer (2001) reported increasing shallow lake water temperatures in the Nether lands, Schneider and Hook (2010) observed rapid surface warming of all inland water bodies since 1985 and Schmidt et al. (2014) found that the lake surface equilibrium temperatures are predicted to increase by 70 to $85 \%$ of the increase in air temperatures as a response to climate change. The maximum difference between surface and bottom water temperatures in stratified lakes is projected to increase by 1 to $2{ }^{\circ} \mathrm{C}$ with a local maximum of $3.2^{\circ} \mathrm{C}$ due to climate warming (Fang and Stefan, 2009). Climate change may force more prolonged stratification in deep lakes or temporary stratification in shallow lakes and increase average annual lake stability affecting ecological functioning of the lake (Section 7; Jensen and Andersen, 1992; Sahoo et al., 2015; Søndergaard et al., 2003). Higher lake temperatures also change the sol ubility of minerals, their reaction kinetics and the resulting chemical profiles (Fang and Stefan, 2009; Löffler, 2003; Yu et al., 2010).

Increasing air temperatures as predicted by climate change will af fect groundwater. Many gravel pit lakes are flow through lakes fed by

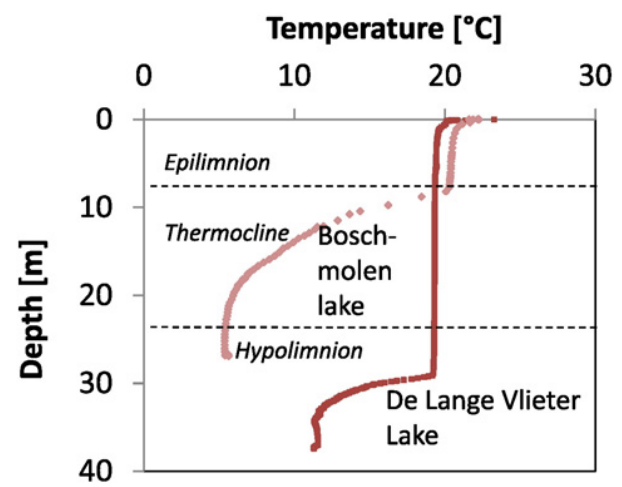

Fig. 13. Summer temperature profiles in gravel pit lake De Lange Vlieter (The Netherlands) with river water infiltration, and air blowers and no stratification and in the Boschmolen lake without artificial mixing, and stratification into epilimnion, thermocline and hypolimnion.

Modified from Mollema et al., 2015a. groundwater. As a result, a change in temperature of in flowing groundwater will affect the gravel pit lake water. However changes in groundwater temperature due to changes in air temperature are much smaller than changes in direct warming of surface water, so that their effect on hydrochemical processes is likely to go unnoticed (Bonte et al., 2013).

\section{Implications of land-use and climate change on chemical and eco- logical aspects of gravel pit lakes}

The consequences of climatic change will be felt in all functions of gravel pit lakes including the chemical cycles and the ecological functioning. In reality, changes in hydrology, water chemistry and ecological functioning are strongly related. A change in water chemistry will change lake ecology and vice versa, a change in the ecology will influ ence the chemical cycles. The separation into distinct paragraphs below on changes in nutrient, carbon, metal cycling and in ecological functioning are therefore only to facilitate reading. Where links exist be tween the changes in different functions of gravel pit lakes, they are indicated.

\subsection{Nutrient cycling under climate and land use change}

There are several possible effects of climate change on the nutrient cycle of gravel pit lake systems. In case of enhanced average annual amount of precipitation, for example, the flux of nutrients in cultivated areas from groundwater into gravel pit lakes could increase as foreseen for other surface waters in North Europe, enhancing eutrophication and risk of algal bloom (Andersen et al., 2005; Jeppesen et al., 2009, 2012; Smith and Schindler, 2009; Trolle et al., 2015). On the other hand, a fu ture decrease in average annual precipitation could limit the influx of nutrients into surface water as predicted for the Netherlands (Visser et al., 2012) and also observed in some gravel pit lakes along the river Meuse (Boschmolen plas and Anna's Beemd, Mollema et al., 2015a). Better management practices and policy guidelines that aim to reduce the nutrient load into groundwater may also lead to a long term (years decades) reduction in nutrient load (Weiske et al., 2013). It has been difficult until now to separate the effect of changes in climate from changes in land use on nutrient concentration in ground and sur face water (Jeppesen et al., 2014). Climate change itself induces a land use change: more forests will grow and terrestrial production will in crease in areas receiving sufficient precipitation, whereas the opposite will happen under drier conditions (Hessen et al., 2009). On a long term scale (decades to centuries) changes in catchment properties will regulate the flux and fate of $\mathrm{C}, \mathrm{N}, \mathrm{P}$, in catchments, while on a 
shorter time scale (seasonal e.g. Søndergaard et al., 2005; years to decades) changes in anthropogenic effects on the $\mathrm{N}$ cycle, temperature, precipitation patterns, and soil or root processes will be dominant. Regardless of a load reduction into gravel pit lakes, the $\mathrm{P}$ concentration may still remain high, particularly in shallow eutrophic (gravel pit) lakes, due to a high natural internal load within the lake sediments (Cross et al., 2014; Fisher et al., 2009; Jeppesen et al., 2014; Ozen et al., 2010). See Section 7.4 for relationship between nutrients, ecological functioning and seasonal changes.

\subsection{Carbon and Ca cycling under climate and land use change}

The effects of acid rain in the first part of the 20th century and of climate change in its latter part confuses the analysis of changes in $\mathrm{pH}$ and temperature that influence the carbonate equilibrium and carbon cycle in surface waters. No studies on gravel pit lakes in particular are available but some studies on natural lakes give insight into changes that may occur in gravel pit lakes. The average long term Dissolved organic carbon (DOC) of lake water may increase due to enhanced annual aver age precipitation, runoff, and groundwater inflow related to changes in terrestrial vegetation cover, wetlands and ice melting (Liu et al., 2010; Tranvik et al., 2009). Instead average annual runoff and DOC may de crease over the next few decades in the Mediterranean region where as much as a $2530 \%$ decrease in freshwater runoff is expected by 204061 (Giorgi and Lionello, 2008). Boreal lakes are known to change from being a source of $\mathrm{CO}_{2}$ to sequestering $\mathrm{CO}_{2}$ (Finlay et al., 2015), ex plained by accumulating $\mathrm{CO}_{2}$ under ice in winter. On the other hand, the carbon efflux in form of $\mathrm{CO}_{2}$ emission from lakes could instead increase in response to elevated temperatures and increased hydrological delivery of mineralizable dissolved organic matter (Tranvik et al., 2009). The amount of organic carbon in lake sediments could diminish as mineral ization of organic carbon in lake sediments exhibits a strongly positive relationship with temperature (Gudasz et al., 2010). A decrease in or ganic content of lake bottom sediments over a period of 10 years was observed in a gravel pit lake in the Netherlands (Mollema et al., 2015a) but it is difficult to separate the effect of the use of the lake for artificial recharge from other processes. The solubility of $\mathrm{CaCO}_{3}$ could decrease due to higher epilimnic water temperatures and higher $\mathrm{pH}$ that change the carbonate buffering conditions in lakes (Walpersdorf et al., 2004) as observed in boreal lakes (Jeziorski et al., 2008) and alpine lakes (Psenner and Schmidt, 1992), and in rivers (Meybeck, 2003). Analysis of alkalinity trends in rivers of the USA (Stets et al., 2014) and of small head water systems (Chen and Lin, 2009) relates an alkalin ity increase over years and decades to recovery from acidification and lime use in agriculture. Although changes in nitrate leaching over years to decades to gravel pit lakes and reservoirs has been observed (Mollema et al., 2015a, b; Weiske et al., 2013) the relationship to the carbon and calcium cycle has not been documented yet.

\subsection{Metal and trace element cycling under climate and land use change}

The metal cycles of a catchment and its gravel pit lakes are closely re- lated to the acidity and redox potential of ground and surface water in the catchment and to input of $\mathrm{NO}_{3}$ and $\mathrm{PO}_{4}$. If one of these parameters changes, also the amount of dissolved metals in the gravel pit lakes and the amount or type of metal oxides deposited on the lake bottom may change. An increase of dissolved As concentration in a reservoir was thus correlated to a decrease in agricultural fertilizer use, explained by a release of As from reservoir bottom sediments (Weiske et al., 2013). In the future, because of reduced application of fertilizers, the $\mathrm{NO}_{3}$ concentration is expected to decrease. This could lead to less avail able oxygen (either as $\mathrm{DO}$ or $\mathrm{NO}_{3}$ ) that influences biochemical cycles (e.g. P release from sediments). The average lake water $\mathrm{pH}$ may change over a period of years to decades as a consequence of climate change, re covery from acid rain or a change in land use (less fertilizers) as ob served for other types of lakes and rivers. With changes in $\mathrm{pH}$, alkalinity or $\mathrm{NO}_{3}$, the reactions that caused the deposition of the metals and trace elements on the lake bottom may be reversed and metals and trace elements may go again into solution. This could possibly create a toxic environment for plants, animals and humans. A change in ground water and lake temperature has an effect on the solubility of metals as was observed for Al by Veselý et al., 2003: higher temperature caused lower Al mobilization in soil horizons and/or enhanced precipitation of Al in natural lakes. Given enough time, all (trace) metals and organic material will be leached from aquifers upstream to gravel pit lakes. This will require hundreds or thousands of years at the current natural recharge rates since many pore volumes of water flushing the aquifer are needed to leach only small parts of the solid rock matrix (Antoniou et al. 2013). Climate change may affect those recharge rates and consequently aquifer and lake hydrochemistry including metal mo bilization. For example, Visser et al. (2012) predicted that reduced groundwater flow associated with droughts would reduce the leaching of heavy metals to surface waters in a Dutch catchment.

\subsection{Ecological functioning under climate and land use change}

Biodiversity, ecosystem services and the benefits to society that flow from them are increasingly threatened by habitat loss and fragmentation and climate change, among others. This holds true also for gravel pit lakes although few specific studies have been done so far on these particular types of lakes. Species will respond differently to climate change and thus new communities of species will form with unknown consequences for ecosystem functioning (e.g. Walker and Steffen, 1997). Many gravel pit lakes are isolated and as such form a fragmented ecosystem, from which species cannot easily move away to other habitats (e.g. Malcolm et al., 2002). Certain 'niche' parameters may not change in the same way or at the same rate as certain climate parameters, resulting in the appearance of new habitats in gravel pit lakes. Changing interactions between different species are difficult to predict as each species reacts differently to climate change (e.g. Lavergne et al., 2010). Furthermore, invasion of alien species is already a worldwide problem and will also affect gravel pit lakes.

Gradual changes in temperature (Scheffer, 2001) with depth in lakes as well as changes in water residence time (Reynolds, 2004) will affect the timing and presence of the clear water phase: warm winter and spring conditions can lead to an earlier and longer lasting clear water phase than in cold winters, owing to earlier life cycle development of zooplankton and longer periods of zooplankton survival (Straile, 2000). In addition to gradual changes, hydrological extremes can suddenly alter the properties of lake ecosystems (Cross et al., 2014). Longer water residence times, for example, may lead to phytoplankton blooms which can significantly deplete the in lake concentrations of $\mathrm{NO}_{3} \mathrm{~N}$ and $\mathrm{SiO}_{2}$ (Cross et al., 2014; Reynolds, 2004). Deeper lakes respond differ ently to changes than shallow lakes, the latter showing a positive trend in total $\mathrm{N}$ and total $\mathrm{P}$ loss with increasing temperature, most likely related to macrophyte growth (Coppens et al., 2015).

Increasing nutrient load in combination with higher water temperatures and more intense and longer stratification as well as the fact that cyanobacteria have a large tolerance for water temperature and salinity ranges may lead to a dominance of these toxic bacteria (Paerl and Paul, 2012; Wagner and Adrian, 2009 and references therein). In some natural lakes, the changes in hydrology and input of $\mathrm{N}$ from the catchment have a larger influence on the $\mathrm{N}$ budget of lakes than climatic effects related to temperature, salinity and water level (Olsen et al., 2015). Hydrochemical or physical changes in lake water will most likely alter species and ecosystems. However, Craig et al. (2015) found that for shallow temperate lakes the availability of a well oxygenated habitat can compensate for lack of DOC or light limitation of benthic primary production. Temperature increases and heat waves have been shown to affect the submerged macrophytes, which showed adaptive changes in growth and asexual reproduction (Cao et al., 2015). 
In the Mediterranean and other arid and semi arid regions, the warmer temperatures may enhance evaporation and evapotranspiration that can lead to increased salinity in gravel pit lakes and other surface waters (Williams, 2001; Mollema et al., 2015b), with negative effects on the diversity of phytoplankton, zooplankton, macro invertebrates and fishes (Cucchiari et al., 2008; Jeppesen et al., 2014; Brucet et al., 2012) as well as on vegetation (Antonellini and Mollema, 2010). The reduction in the size and abundance of zooplankton grazers due to enhanced sa linity may further negatively affect the resilience of lakes to enhanced nutrient loading (Brucet et al., 2012).

\section{Future research directions}

\subsection{Water budget measurements}

The water budget of gravel pit lakes includes two components that are not easy to measure directly or quantify: surface water evaporation and groundwater inflow. Direct measurement of surface water evapora tion in lakes is notoriously time consuming and complicated although floating evaporation pans have been developed and successfully tested (Masoner et al., 2008, 2007; Masoner and Stannard, 2010). Placing evaporation pans close to but not on the lake water surface is more prac tical but less representative. Pan evaporation trends, however, show de creasing surface water evaporation despite global warming indicating that the interplay between climate variables on evaporation needs more fundamental physical research (Fu et al., 2009). Most methods for determining surface water evaporation (or evapotranspiration) are based on formulae developed for example by Penman Monteith or Thorntwaite that use climate data. It is known, however, that small lakes have different surface evaporation rates than large lakes (e.g. Maidment, 1992; Winter et al., 1995 ) and it is even more difficult to measure evaporation rates over multiple gravel pit lakes. Remote sens ing data is increasingly used to quantify components of the water bud get over large areas, in particular of soil moisture (see Seneviratne et al., 2010 for a review) and changes in groundwater storage (Green et al., 2011; Yeh et al., 2006) or vegetation and evapotranspiration (e.g. Pôças et al., 2013). This type of study could be helpful in large catch ments with gravel pit lakes. If the amount of surface evaporation and the stable isotope composition of the so called evaporation end mem ber $\left(\delta^{2} \mathrm{H}\right.$ and $\left.\delta^{18} \mathrm{O}\right)$ are known, a mass balance equation (e.g. Skrzypek et al., 2015) can be used to determine the amount of groundwater flowing into gravel pit lakes, as demonstrated for natural lakes (e.g. Gibson et al., 1993, 2008; Mayr et al., 2007) and applied to gravel pit lakes by Jones et al. (2016) and Mollema et al. (2015a, b). Better under standing of the fractionation of stable isotopes in various parts of a catchment, on small lakes and in particular in gravel pit lakes under var ious climatic conditions is needed. Tracer studies using other environmental (natural) tracers than stable $\mathrm{H}$ or $\mathrm{O}$ isotopes in combination with modeling may help to understand flow paths and residence time of water in gravel pit lakes. These include tracers that have a known rate of decay or fractionation (e.g. ${ }^{39} \mathrm{Ar},{ }^{14} \mathrm{C},{ }^{36} \mathrm{Cl}$ ) or are non reactive while in the subsurface (e.g. noble gas isotopes) or those that accumu late over the time spent in the subsurface (e.g. ${ }^{36} \mathrm{Cl},{ }^{3} \mathrm{He},{ }^{4} \mathrm{He}$; see for an overview Turnadge and Smerdon, 2014). Another type of tracer is heat as used in groundwater flow (Anderson, 2005).

Groundwater flow into gravel pit lakes could be measured by seep age meters as used in studies of submarine groundwater discharge (e.g. Taniguchi et al., 2006) or by geophysical measurements as done in nat ural lakes (Nyquist et al., 2009). In combination with all these methods, hydrological modeling including watershed modeling will help reduce uncertainties in water budgets (e.g. Kauffeldt et al., 2016). The effect of lakes themselves on changes in climate is not yet completely under stood and (small) lakes need to eventually be incorporated in weather prediction and climate models as sources for atmospheric moisture (Mironov et al., 2010).

\subsection{Hydrochemistry, ecological functioning and biomanipulation}

So far, few detailed hydrochemical studies of gravel pit lakes have been published. With time, more data will become available and the more subtle differences between the hydrochemistry of gravel pit lakes in different hydrogeologic settings (glacier, fluvial, coastal setting) may become clear (e.g. Stephenson et al., 1988). Long term monitoring over years and decades of lake water and groundwater quality as well as the ecology will help to better understand and separate the effects of land use change upstream from gravel pit lakes from those caused by climate change, including extreme climate change (Trolle et al., 2015). It is important to consider many aspects of the catchment containing gravel pit lakes including climate, and river, groundwater and surface water quality. To this end, both water fluxes and water quality need to be monitored. In particular, it is important to be able to take ground water samples from specific depths without mixing shallow and deep groundwater, for example by constructing multilevel samples with minifilters (e.g. Pickens et al., 1978; Butler et al., 1999; Einarson and Cherry, 2002). This monitoring methodology will also help to better map the heterogeneities in aquifer material with the role of specific or ganic layers associated with particular metals (for example $\mathrm{Al}$ ) becom ing more apparent. In some situations, groundwater flows in and out of one gravel pit lake and then into another gravel pit lake. As far as we know, it is currently unknown how the multiple transit of ground water through lakes affects ground and lake water properties. Most hydrochemical studies of gravel pit lakes now focus on nutrients, eutro phication, the foodweb, major ion chemistry or (trace) metals. There are many other chemical elements that need to be researched for their en vironmental impact, for their possible use as tracers of flow paths or to determine the hydrochemical processes that occur both in the aquifer and in gravel pit lakes. These include organic contaminants, pathogens, pesticides, and pharmaceutical compounds. Another challenge in studying gravel pit lakes is the collection of water or sediment from the lake bottom or below as it is expensive and time consuming and not always routinely done, especially if the lakes are deep $(>20 \mathrm{~m})$. This would, however, help to increase our knowledge of redox cycling and the speciation of metal oxides and other compounds including $\mathrm{P}, \mathrm{C}$, trace elements and metals that are deposited on gravel pit lake bottoms, and to follow changes in their concentration over time.

The hydrological and hydrochemical changes need to be studied in relation to ecosystem changes, especially with regards to the effects of extreme variations in water level and salinity in lakes due to extreme climate events (Jeppesen et al., 2015). For example, drought related reacidification effects on water chemistry is thought to have important effects on algal communities in acid sensitive lakes with modest wet land coverage (Faulkenham et al., 2003).

To better understand the ecological response to changes in climate or land use and the explicit links between species evolution, species as semblages, and ecosystem functioning, the study of evolutionary biolo gy and community ecology needs to be combined (see Lavergne et al., 2010 and references for a review) with (hydro)chemical (e.g. Appelo and Postma, 2005) and ecological (Turner et al., 2016) modeling. The genetic alteration or adaptation of one particular species to (climatic) changes will affect the whole ecosystem and complicated feedbacks are recognized to exist (Lavergne et al., 2010). For example, stratifica tion in lakes in temperate areas may persist over longer periods of the year (Sahoo et al., 2015), extending the reproductive season of plankton with consequences for the whole food web. Because gravel pit lakes are typically in densely populated and agricultural countries, nutrient levels and eutrophication (Muellegger et al., 2013), in particular with toxic cyanobacteria (Cross et al., 2014), are a reason for concern. Possible management strategies to cope with external or internal nutrient load ing are, for example, chemical treatment of the water to precipitate phosphorus and to reduce internal phosphorus loading and thus phyto plankton growth. Another possibility restricted to (summer) stratified lakes is to add oxidizers to an otherwise anoxic hypolimnion, for 
example with air pumps that introduce oxygen. Alternatively nitrate may be used as an oxidizer but caution is needed to avoid eutrophication and (toxic) algal blooms. Often these chemical methods are applied together with biomanipulation that generally includes eliminating or introducing certain plant or animal species (Jeppesen et al., 2012; Smolders et al., 2006). This has been done in gravel pit lakes (Giles, 1994; Jeppesen et al., 2012; Søndergaard et al., 1990). While this ap proach has worked well in many cases in northern and temperate lakes where there is a period of low or no reproduction, it has proven more complicated in Mediterranean or (sub)tropical lakes where bio mass, biodiversity and species richness tends to be larger and the eco systems more complicated and where reproduction occurs (almost) year round (Jeppesen et al., 2012). In natural lakes, phytoplankton is controlled by removal of zooplankton or benthic omnivorous fish, and stocking of predatory or pelagic herbivorous fish (see review in Jeppesen et al., 2012). Macrophyte transplantation to offer habitat for zooplankton or instead introduction of herbivorous fish to control the growth of macrophytes is another method to control phytoplankton (see Jeppesen et al., 2012 and references for an overview). Whether macrophytes are successful in a lake depends among others on whether the lake sediments have sufficient organic content and limited toxic substances (e.g. Smolders and Roelofs, 1996).

Besides biomanipulation there are hydrologic interventions that may help to maintain water quality and ecosystem stability. These include water table management and hydrological connectivity to the river system of fluvial gravel pit lakes. In addition, adding Fe or other chemical elements which naturally bind to phosphate may help control lake water quality and ecosystem functioning (Geurts et al., 2008; Immers et al., 2015; Smolders et al., 2006).

Controlling nutrient concentrations and eutrophication while at the same time making gravel pit lakes suitable for specific ends may be difficult. For example, the artificial recharge with nutrient rich river water of a Dutch gravel pit lake leads to high $\mathrm{NO}_{3}$ concentrations so that air blowers are needed to prevent eutrophication and degraded water quality. Another possible conflict may arise between recreational users and nature conservation of gravel pit lakes. For example, macrophytes will help to restore shallow lakes and to clear the water but if plants be come abundant they will cause nuisance to boating and swimming and obstruct water flow (van Nes et al., 2002). Vice versa recreational activ ities may disturb certain species such as birds (Pochard; Fox et al., 1994). Possibly different uses of gravel pit lakes, for example the storage of heat (Novo et al., 2010), will present new challenges as it affects the hydrochemistry as well as the ecology in as yet unknown ways. All this will be controlled by policy guidelines as for example those of the Water Framework Directive (WFD; European Commision, 2000) with special elaboration for groundwater (European Commision, 2006a) and on dis charges of certain dangerous substances (European Commision, 2006b) as well as on the technical specifications for chemical analysis and mon itoring of ground and surface water status (European Commision, 2009). Gravel pit lakes are not mentioned as a separate type of environ ment to monitor but they fall under inland surface waters, groundwater, transitional waters and coastal waters.

Eventually we should be able to better understand the effect of a sys tem of multiple (tens of) gravel pit lakes not only on the catchment near the lakes but also on the chemical budget downstream in the estuary and its offshore area. For example, one gravel pit lake is estimated to 'trap' the following quantities of metals in its bottom sediments: Ni $113 \mathrm{~kg}$ year $^{-1}$, Zn $1439 \mathrm{~kg}$ year $^{-1}$ and Fe 16,676 kg year

-1 (Mollema et al, 2015a). Assuming these values are representative for the catch ment then the 71 gravel pit lakes present in the catchment together pre vent 1.3 million $\mathrm{kg}$ of metal to reach the (submarine) estuaries and shore downstream. The transport of other metals is also likely to be sig nificantly affected. Dissolved metals and other solutes play an important role in coastal ground water and submarine estuaries and changing the budgets of these solutes upstream affects the ecosystem along the coast (Moore and Shaw, 2008 and references therein).

\section{Summary and conclusions}

Gravel pit lakes are excavated in gravel deposits along rivers, in glacial valleys and in old beach gravel deposits to fulfill the need for build ing materials. In some cases, many (tens) of these lakes have formed close to one another creating, in aggregate form, a large new open water surface. The gravel pit lakes change the environment in many ways concerning landscape, land use, the hydrology, hydrochemistry, biochemistry and ecology and may exist for thousands of years. The drainage pattern of a catchment changes in presence of gravel pit lakes possibly causing changes of the water table over a large area. If oc curring in a coastal zone, these fluctuations and the presence of the gravel pit lakes will enhance salt water intrusion. Gravel pit lakes can be flow through lakes where groundwater moves through the lake downstream towards a river or other draining feature. Water budget calculations show that catchments with many gravel pit lakes in temperate and Mediterranean areas are much more sensitive to changes in evaporative losses caused by climate change than they would be without gravel pit lakes. Gravel pit lakes studied in great detail so far occur in fluvial and coastal settings and are relatively alkalinity and Ca rich, most similar to 'marl' lakes or 'nutrient rich' lakes. When groundwater flows into gravel pit lakes, the concentration of many dissolved elements changes due to redox, precipitation and dissolution reactions. Gravel pit lake water therefore is typically enriched or depleted in specific chemical components with respect to the inflowing ground water. Gravel pit lake water shows (on the basis of the reviewed studies) a smaller variation than natural lakes in $\mathrm{pH}$ and concentration in $\mathrm{HCO}_{3}$ and metals (e.g. Fe, Ni). Gravel pit lakes influence the nutrient cycle of a catchment by incorporating $\mathrm{N}$ and $\mathrm{P}$ that flows into the lake with groundwater or atmospheric deposition in biomass and bottom sediments. The nutrient cycle is related to the carbon and metal chemical cycles as fertilization upstream from the lakes mobilizes metals in groundwater that eventually are incorporated into bottom lake sediments. In this way, gravel pit lakes may contribute to denitrification of groundwater but they may also enhance the mobilization of soil bound compounds like metals. Gravel pit lakes offer space for many dif ferent ecological habitats increasing the biodiversity in an agricultural or an urban setting. Plants and animal species including phytoplankton, zoobenthos and macrophytes, fish and birds take part in the chemical cycling of gravel pit lakes among others, by uptake of atmospheric $\mathrm{CO}_{2}$ and $\mathrm{N}_{2}$, uptake of dissolved compounds including $\mathrm{HCO}_{3}$, Fe and $\mathrm{Mn}$; by uptake of elements including $\mathrm{P}$, Fe from lake sediments and by carbon mineralization and burial. Gravel pit lakes typically receive nutrient rich water from rivers or groundwater which may cause eutrophication. The (bio)chemical cycles may change over time since gravel pit lakes have formed only recently and land use and climatic change play a role in their future evolution. Therefore key areas for further research include the study of gravel pit lakes in other settings to better separate the similarities and differences between natural and gravel pit lakes as well as the feedback mechanisms between change in land use, climate and water quality and ecosystem functioning. Understanding these feedback mechanisms as well as the effects of chemical changes or biomanipulation, will help society to use gravel pit lakes efficiently and contemporaneously for multiple uses including ecosystem services, storing water and recreational areas. The planning of new gravel pit lake excavations should include an evaluation of possible freshwater loss by evaporation, chemical processes such as metal accumulation in lake bottoms, and ecological functioning in relation to eutrophication and nutrient fluxes.

\section{Acknowledgements}

We sincerely thank Iain Cross for a very helpful review and Pieter J. Stuyfzand and an anonymous reviewer for reading an earlier version of this manuscript. Thanks to Marianne van Buuren for proofreading the section on ecology. Thanks also to Pieter Stuyfzand (TU Delft) as 
well as to Nicolas Greggio, Beatrice Giambastiani and other students of the University of Bologna and the employees of WML Maastricht (In cluding Maria H.A. Juhasz Holterman, Peter M.J.A van Diepenbeek, Alwin Hubeek, and Esther Dieker) Maastricht for their support during the studies that form the background of this review paper.

\section{Appendix A. List of symbols}

\begin{tabular}{|c|c|}
\hline Symbol (alphabetical order) & Name \\
\hline $\mathrm{Al}$ & Aluminum \\
\hline As & Arsenic \\
\hline $\mathrm{Ba}$ & Barium \\
\hline $\mathrm{C}$ & Carbon \\
\hline $\mathrm{Ca}$ & Calcium \\
\hline $\mathrm{CaCO}_{3}$ & Calcium carbonate \\
\hline $\mathrm{CH}_{4}$ & Methane \\
\hline $\mathrm{Cl}$ & Chlorine \\
\hline $\mathrm{Cl}$ & Chloride ion \\
\hline Co & Cobalt \\
\hline $\mathrm{CO}_{2}$ & Carbon dioxide \\
\hline$\delta^{2} \mathrm{H}(\% \circ \mathrm{vs}$ VSMOW) & Hydrogen 'heavy' isotope, delta notation \\
\hline$\delta^{18} \mathrm{O}(\%$ vs VSMOW) & Oxygen 'heavy' isotope, delta notation \\
\hline DIC & Dissolved inorganic carbon \\
\hline DLV & De Lange Vlieter (gravel pit lake in NL) \\
\hline DOC & Dissolved organic carbon \\
\hline $\mathrm{E} \mathrm{ET}_{\mathrm{a}}$ & Evaporation \\
\hline $\mathrm{Fe}$ & Actual evapotranspiration \\
\hline $\mathrm{H}_{2} \mathrm{~S}$ & Iron \\
\hline $\mathrm{HCO}_{3}$ & Hydrogen sulfide \\
\hline $\mathrm{N} \mathrm{Ni}$ & Bicarbonate \\
\hline $\mathrm{NO}_{3}$ & Nitrogen \\
\hline OCP & Nickel \\
\hline $\mathrm{PO}_{4}$ & Nitrate \\
\hline $\mathrm{pH} \mathrm{Si}$ & Organic carbon \\
\hline $\mathrm{SO}_{4}$ & Phosphorus \\
\hline TDS & Phosphate \\
\hline \multirow[t]{2}{*}{$\mathrm{Zn}$} & Acidity \\
\hline & Silicon \\
\hline \multirow[t]{3}{*}{2} & Sulfate \\
\hline & Total dissolved solids \\
\hline & Zinc \\
\hline
\end{tabular}

\section{Appendix B. Supplementary data}

Supplementary data associated with this article can be found in on line version, at http://dx.doi.org/10.1016/j.earscirev.2016.05.006. These data include the Google map of the most important areas described in this article.

\section{References}

ACIA, 2004. Impacts of a Warming Arctic: Arctic Climate Impact Assessment. Cambridge Univ. Press.

Adrian, R., O'Reilly, C.M., Zagarese, H., Baines, S.B., Hessen, D.O., Keller, W., Livingstone, D.M., Sommaruga, R., Straile, D., Van Donk, E., Weyhenmeyer, G.A., M., W., 2009. Lakes as sentinels of climate change. Limnol. Oceanogr. 54 (6, part 2), 2283-2297. http://dx.doi.org/10.4319/lo.2009.54.6_part_2.2283.

Allen, R.G., Pereira, L.S., Raes, D., Smith, M., 1998. Crop evapotranspiration. Guidelines for computing cropwater requirements. FAO Irrigation and Drainage Paper 56 (ISBN 92-5-104219-5).

Alvarez Cobelas, M., Rubio, A., Velasco, J.L., 1990. Chemical limnology of a hypertrophic gravel-pit lake. Ann. Limnol. 26, 97-108 (1990).

Alvarez Cobelas, M., Haering, F.J., Velasco, J.L., Rubio, A., 1992. The seasonal productivity of phytoplankton in a hypertrophic, gravel-pit lake. J. Plankton Res. 14, 979-996. http://dx.doi.org/10.1093/plankt/14.7.979.

Andersen, M.S., Nyvang, V., Jakobsen, R., Postma, D., 2005. Geochemical processes and solute transport at the seawater/freshwater interface of a sandy aquifer. Geochim.

Cosmochim. Acta 69, 3979-3994. http://dx.doi.org/10.1016/j.gca.2005.03.017. Anderson, M.P., 2005. Heat as a ground water tracer. Ground Water 43 (6), 951-968. Andrews, J., Kinsman, D., 1990. Gravel Pit Restoration for Wildlife A Practical Manual RSPB (184 pp.) Royal Society for the Protection of Birds (RSPB), UK (ISBN: 0903138603).
Antonellini, M., Mollema, P., 2010. Impact of groundwater salinity on vegetation species richness in the coastal pine forests and wetlands of Ravenna, Italy. Ecol. Eng. 36,

1201-1211. http://dx.doi.org/10.1016/j.ecoleng.2009.12.007.

Antoniou, E.A., Stuyfzand, P.J., van Breukelen, B.M., 2013. A Reactive transport modeling of an aquifer storage $\&$ recovery (ASR) pilot to assess long-term water quality improve-ments and potential solutions. Applied Geochemistry 35, 173-186.

Antonov, J.I., Seidov, D., Boyer, T.P., Locarnini, R.A., Mishonov, A.V., Garcia, H.E., Baranova O.K., Zweng, M.M., Johnson, D.R., 2010. World ocean atlas 2009. In: Levitus, S. (Ed.), SalinityNOAA Atlas NESDIS 69 vol. 2. U.S. Government Printing Office, Washington, D.C. (184 pp.).

Appelo, C.A.J., Postma, D., 2005. Geochemistry, Groundwater and Pollution. second ed. CRC Press, New York (649 pp. ISBN 9780415364287).

Arauzo, M., Alvarez Cobelas, M., Vicioso, J., Verdugo Centro, M., 1996. The phytoplankton of some gravel-pit lakes in Spain. Hydrobiologia 333, 19-27.

Balistrieri, L.S., Murray, J.W., Paul, B., 1992. The cycling of iron and manganese in the water column of Lake Sammamish, Washington. Limnol. Oceanogr. 37 (3), 510-528.

Bastviken, D., Tranvik, L.J., Downing, J.A., Crill, P.M., Enrich- Prast, A., 2011. Freshwate methane emissions offset the continental carbon sink. Science 331, 50. http://dx. doi.org/10.1126/science.1196808.

Baveye, P., Vandevivere, P., Hoyle, B.L., DeLeo, P.C., Sanchez de Lozada, D., 1998. Environmental impact and mechanisms of the biological clogging of saturated soils and aqui-fer materials. Crit. Rev. Environ. Sci. Technol. 28 (2), 123-191. http:// dx.doi.org/10. 1080/10643389891254197.

Bayram, A., Önsoy, H., 2015. Sand and gravel mining impact on the surface water quality: a case study from the city of Tirebolu (Giresun Province, NE Turkey). Environ. Earth

Sci. 73 (5), 1997-2011. http://dx.doi.org/10.1007/s12665-014-3549-2.

BBC Wildlife, 2007. Top Ten Ecodestinations of the World vol. 25 (Number 13pp.). (December).

Berner, E.K., Berner, R.A., 1996. Global Environment: Water, Air, and Geochemical Cycles. Prentice Hall, Englewood Cliffs, NJ (376 pp. ISBN: 9780691136783).

Blees, J., Niemann, H., Erne, M., Zopf, J., Schubert, C., 2015. Spatial Variations in Surface Water Methane Super-Saturationand Emission in Lake Lugano, Southern Switzerland http://dx.doi.org/10.1007/s00027-015-0401-z Aquatic (On-line by Aquatic Sciences).

Bleich, S., 2011. $\beta$-diversity as a measure of species turnover along the salinity gradient in the Baltic Sea, and its consistency with the Venice System. Marine Ecology Progress Series 436, 101-118. http://dx.doi.org/10.3354/meps09219.

Blener, J.A., 1979. City of Grand Rapids, Michigan program of industrial waste control. Second Conference on Advanced Pollution Control for the Metal Finishing Presented at

Orlando Hyatt House, Kissimmee, Fl, pp. 55-63 (February 5-7).

Bloesch, J. 2004. Sedimentation and lake sediment formation in: The Lakes Handbook vol. 1: Limnology and Limnetic Ecology by P.E. O'Sullivanand C.S. Reynolds (Eds). Black-well Publishing.

Bluck, B... 2011. Structure of gravel beaches and their relationship to tidal range. Sedimentology 58, 994-1006. http://dx.doi.org/10.1111/j.1365-3091.2010.01192.x994.

Boggs Jr., S., 1987. Principles of Sedimentology and Stratigraphy. Merrill Publishing Company (ISBN 0-675-20487-9).

Bonte, M., Van Breukelen, B.M., Stuyfzand, P.J., 2013. Temperature-induced impacts on groundwater quality and arsenic mobility in anoxic aquifer sediments used for both drinking water and shallow geothermal energy production. Water Res. http://dx. doi.org/10.1016/j.watres.2013.05.049.

Boulton, G.S., 1986. Push-moraines and glacier-contact fans in marine and terrestrial environments. Sedimentology 33 (5), 677-698. http://dx.doi.org/10.1111/j.1365-3091. 1986.tb01969.x.

History of the aggregates industry in the Trent valley (Chapter 4) In: Bridgland, D.R. Howard, A.J., White, M.J., White, T.S. (Eds.), Quaternary of the Trent. Oxbow Books (ISBN: 9781842174616|Published by:).

Brucet, S., Boix, D., Nathansen, L.W., Quintana, X.D., Jensen, E., et al., 2012. Effects of temperature, salinity and fish in structuring the macroinvertebrate community in shallow lakes: implications for effects of climate change. PLoS One 7 (2), e30877. http://dx.doi.org/10.1371/journal.pone.0030877.

Bruland, K.W. Lohan, M.C., 2003. Controls of trace metals in seawater. Treatise Geochem. 6, 23-47 (ISBN: 0-08-044341-9).

Bustos-Medina, D., van den Berg, G.A., van Breukelen, B.M., Juhasz- Holterman, M., Stuyfzand, P.J., 2013. Iron hydroxide clogging of public supply wells receiving artificial recharge: near-well and in-well hydrological and hydrochemical observations. Hydrogeol. J. 21 (7), 1393-1412. http://dx.doi.org/10.1007/s10040-013-1005-0.

Butler, J.J., McElwee, C.D., Bohling, G.C., 1999. Pumping tests in networks of multileve sampling wells: motivation and methodology. Water Resour. Res. 35 (11),

3553-3560. http://dx.doi.org/10.1029/1999WR900231.

Cao, Y., Neif, E.M., Li, W., Coppens, J., Filiz, N., Lauridsen, T.L., Davidson, T.A., Søndergaard, M., Jeppesen, E., 2015. Heat wave effects on biomass and vegetative growth of mac-rophytes after long-term adaptation to different temperatures: a mesocosm study. Clim. Res. 66, 265-274. http://dx.doi.org/10.3354/cr01352 (2015).

Cattaneo, A., Steel, R.J., 2003. Transgressive deposits: a review of their variability. Earth Sci. Rev. 62, 187-228. http://dx.doi.org/10.1016/S0012-8252(02)00134-4.

CBS, PBL, Wageningen UR, 2016. Winning en Verbruik Van Oppervlaktedelfstoffen, 2000 2013 (Indicator 0067, Versie 15, 21 April 2016) (www. compendiumvoordeleefomgeving.nl) CBS, Den Haag; Planbureau voor de Leefomgeving, Den Haag/Bilthoven en Wageningen UR, Wageningen.

Chapman, B.R., Ferry, B.W., Ford, T.W., 1997. Phytoplankton communities in water bodies at dungeness, U.K.: analysis of seasonal changes in response to environmental factors. Hydrobiologia 362, 161-170.

Chen, Y., Lin, L.-S., 2009. Responses of streams in central Appalachian Mountain region to reducedacidic deposition-comparisons with other regions in North America and Eu-rope. Sci. Total Environ. 407, 2285-2295. http://dx.doi.org/10.1016/ j.scitotenv.2008. 11.035 
Choi, B.-Y., Yun, S.-T., Mayer, B., Kim, K.-H., 2011. Sources and biogeochemical behavior of nitrate and sulfate in an alluvial aquifer: Hydrochemical and stable isotope ap-

proaches. Applied Geochemistry 26 (7), 1249-1260.

CMRA, 2014. http://www.concreterecycling.org/engineering.html.

Codd, G.A., 2000. Cyanobacterial toxins, the perception of water quality, and the prioritisation of eutrophication control. Ecol. Eng. 16 (1), 51-60.

Cole, J.J., Prairie, Y.T., Caraco, N.F., McDowell, W.H., Tranvik, L.J., Striegl, R.G., Duarte, C.M. Kortelainen, J.A., Downing, J.J., Middelburg, Melack, J., 2007. Plumbing the global car-bon cycle: integrating inland waters into the terrestrial carbon budget. Ecosystems 10, 171-184. http://dx.doi.org/10.1007/s10021-006-9013-8.

Conkright, M.E., Gregg, W.W., Levitus, S., 2000. Seasonal cycle of phosphate in the open ocean. Deep-Sea Res. 47, 159-175. http://dx.doi.org/10.1016/

S0967-0637(99)00042-4

Coppens, J., Hejzlar, J., Michal, S., Jeppesen, E., Coppens, J., Hejzlar, J., Michal, S., Jeppesen, E., 2015. The influence of nutrient loading, climate and water depth on nitrogen and phosphorus loss in shallow lakes: a pan-European mesocosm experiment. Hydrobiologia http://dx.doi.org/10.1007/s10750-015-2505-9.

Craig, N., Jones, S.E., Weidel, B.C., Solomon, C.T., 2015. Habitat, not resource availability, limits consumer production in lake ecosystems. Limnol. Oceanogr. 60, 2079-2089.

http://dx.doi.org/10.1002/lno.10153.

Cross, I.D., 2009. The Effects of Nutrients and Hydrology on Shallow Lake Plankton at Attenborough Nature Reserve, Nottinghamshire (PhD thesis) University of Notting-ham (426 pp.).

Cross, I.D., McGowan, S., Needham, T., Pointer, C.M., 2014. The effects of hydrological extremes on former gravel pit lake ecology: management implications. Fundam. Appl. Limnol/Arch. Hydrobiol. 185 (1), 71-90. http://dx doi.org/10.1127/fal/2014/0573.

Cucchiari, E., Guerrini, F., Penna, A., Totti, C., Pistocchi, R., 2008. Effect of salinity, temperature, organic and inorganic nutrients on growth of cultured Fibrocapsa japonica (Raphidophyceae) from the northern Adriatic Sea. Harmful Algae 7, 405-414. http://dx.doi.org/10.1016/j.hal.2007.09.002.

Danielopol, D.L., Pospisil, P., Rouch, R., 2000. Biodiversity in groundwater: a large scale view. Trends Ecol. Evol. 15, 223-224. http://dx.doi.org/10.1016/

S0169-5347(00)01868-1.

De la Loma Gonzalez, B., van Beek, C.G.E.M., Hubeek, A.A., Kessels, W.T.J., 2013. Description of well Clogging after 10 Years Artificial Recharge at well Field Heel (WML) BTO 2012.036(s)

De Vente, J., Poesen, J., Verstraeten, G., 2005. The application of semi-quantitative

methods and reservoir sedimentation rates for the prediction of basin sediment yield in Spain. J. Hydrol. 305, 63-86. http://dx.doi.org/10.1016/j.jhydrol.2004.08.030. Delleur,

J.W., 2010. The Handbook of Groundwater Engineering. second ed. CRC Press, New York (ISBN 0-8493-2698-2).

Deskundigencommissie zandwinputten, 2009. Verantwoord Grootschalig toepassen van grond en baggerspecie. Rapport van de Deskundigencommissie Hoofdrapport Juni

2009.

Doyle, G.A., Runnells, D.D., 1997. Physical limnology of existing mine pit lakes. Min. Eng. 49, 76-78.

Du Laing, G., Rinklebe, J., Vandecasteele, B., Meers, E., Tack, F.M.G., 2009. Trace metal behaviour in estuarine and riverine floodplain soils and sediments: a review. Sci. Tota Environ. 407, 3972-3985. http://dx.doi.org/10.1016/j.scitotenv.2008.07.025.

Duarte, C.M., Prairie, Y.T., 2005. Prevalence of heterotrophy and atmospheric $\mathrm{CO}_{2}$ emissions from aquatic ecosystems. Ecosystems 8, 862-870. http:// dx.doi.org/10.1007/s10021-005-0177-4.

Duarte, C.M., Prairie, Y.T., Montes, C., Cole, J.J., Striegl, R.G., Melack, J., Downing, J.A., 2008. $\mathrm{CO}_{2}$ emissions from saline lakes: a global estimate of a surprisingly large flux. J. Geophys. Res. 113, G04041. http://dx.doi.org/10.129/2007JG000637.

Dykyjova, D., Ulehlova, B., Westlake, D.F., 1998. Mineral economy and cycling of minerals in wetlands. In: Kvet, J., Szczepanski, A. (Eds.), The Production Ecology of Wetlands. Cambridge University Press, Cambridge, pp. 319-366.

Einarson, M.D., Cherry, J.A., 2002. A new multilevel ground water monitoring system using multichannel tubing. Ground Water Monit. Rem. 22 (4), 52-65. http:// dx.doi. org/10.1111/j.1745-6592.2002.tb00771.x.

Einsele, G., Yan, J., Hinderer, M., 2001. Atmospheric carbon burial in modern lake basin and its significance for the global carbon budget. Glob. Planet. Chang. 30, 167-195.

http://dx.doi.org/10.1016/S0921-8181(01)00105-9.

European Commision, 2000. Directive 2000/60/EC of the European Parliament and of the council of 23 October 2000 establishing a framework for community action in the field of water policy (water framework directive). Off. J. Eur. Communities (C, L 327 $22 / 12 / 2000$ ).

European Commision, 2006a. Council Directive on Pollution Caused by Discharges of Certain Dangerous Substances (Directive 76/464/EEC, Codified as 2006/11/EC)

European Commision, 2006b. The Groundwater Directive 2006/118/EC Developed in Response to the Requirements of Article 17 of the Water Framework Directive. European Commision, 2009. Commission Directive 2009/90/EC on Technical Specifications for Chemical Analysis and Monitoring of Water Status.

Fang, X., Stefan, H.G., 2009. Simulations of climate effects on water temperature, dissolved oxygen, ice and snow covers in lakes of the contiguous U.S. under past and future cli-mate scenarios. Limnol. Oceanogr. 54 (6), 2359-2370. http:// dx.doi.org/10.4319/lo. 2009.54.6_part_2.2359.

Fang, X., Chang, N., Lee, M., Wolf, L., 2009. Environmental impacts on surface water and groundwater for expanding urban water supply capacity using stone quarries. World Environmental and Water Resources Congress 2009, pp. 1-12 http:// dx.doi. org/10.1061/41036(342)189.

Fang, X., Chang, N.-B., Lee, M.-K., Wolf, L.W., 2010. Environmental assessment of using stone quarries as part of an integrative water supply system in fast growing urban regions. In: Chang, N.-B. (Ed.), The Effects for Urbanization on Groundwater: An Engineering Case Based Approach for Sustainable Development. American Society of
Civil Engineers, pp. 26-50 (http://books.google.nl/books?id=nKk_yNPs6mEC\&pg = PA33\&dq $=\% 22$ quarry + lake\%22greenspring\&hl $=$ en\&sa $=X \& e i=$

D9nHT96TN6Tx0gG2ienBDw\&redir_esc =y\#v=onepage\&q=\%22quarry\%20lake\% 22greenspring\&f=false)

FAO, 2015. AQUASTAT Website. Food and Agriculture Organization of the United Nations (FAO) (Website accessed on [2015/09/30])

Faulkenham, S.E., Hall, R.I., Dillon, P.J., Karst-Riddoch, T., 2003. Effects of drought-induced acidification on diatom communities in acid-sensitive Ontario lakes. Limnol. Oceanogr. 4. http://dx.doi.org/10.4319/lo.2003.48.4.1662.

Finlay, K., Vogt, R.J., Bogard, M.J., Wissel, B., Tutolo, B.M., Simpson, G.L., Leavitt, P.R., 2015. Decrease in $\mathrm{CO}_{2}$ efflux from northern hardwater lakes with increasing atmospheric warming. Nature http://dx.doi.org/10.1038/nature14172.

Fisher, J., Barker, T., James, C., Clarke, S., 2009. Water quality in chronically nutrient-rich lakes: the example of the Shropshire-Cheshire meres. Freshwat. Rev. 2 (1), 79-99. http://dx.doi.org/10.1608/FRJ-2.1.5.

Florsheim, J.L., Chin, A., Gaffney, K., Slot, D., 2013. Thresholds of stability in incised "Anthropocene" landscapes. Anthropocene 2, 27-41. http://dx.doi.org/10.1016/j. ancene.2013.10.006

Fox, A.D., Jones, T.A., Singleton, R., Agnew, A.D.Q., 1994. Food supply and the effects of recreational disturbance on the abundance and distribution of wintering Pochard on a gravel pit complex in southern Britain. Hydrobiologia 279-280, 253-261.

Fu, G.B., Charles, S.P., Yu, J.J., 2009. A critical overview of pan evaporation trends over the last 50 years. Clim. Chang. 97, 193-214. http://dx.doi.org/10.1007/ s10584-009-9579-1.

Gammons, C.H., Harris, L.N., Castro, J.M., Cott, P.A., Hanna, B.W., 2009. Creating lakes from open pit mines: processes and considerations - with emphasis on northern environ-

ments. Can. Tech. Rep. Fish. Aquat. Sci. 2826 (ix + 106 pp.)

Gandy, C.J., Younger, P.L., 2008. Predicting long-term contamination potential of perched groundwater in a mine-waste heap using a random-walk method. Hydrogeol. J. 16, 447-459. http://dx.doi.org/10.1007/s10040-007-0243-4

Gandy, C.J., Younger, P.L., Henstock, J., Symonds Group, Gill, T., Symonds Group, Wardrop, D., Lafarge Aggregates Ltd, 2004. The Hydrogeological Behaviour of Flooded Sand and Gravel Pits and its Implications for the Functioning of the Enclosing Aquifers Mineral Industry Sustainable Technology (MIST) Programme Hydrogeochemical Engineering Research and Outreach (HERO). University of Newcastle Upon Tyne, UK.

Garnier, J., Billen, G., 1994. Ecological interactions in a shallow sand-pit lake (Lake Créteil, Parisian Basin, France): a modelling approach. Hydrobiologia 275-276, 97-114.

http://dx.doi.org/10.1007/978-94-017-2460-9_9.

Garrels, R.M., Mackenzie, F.T., 1971. Evolution of Sedimentary Rocks. W.W. Norton and Co., New York (397 pp.).

Geurts, J.J.M., Smolders, A.J.P., Verhoeven, J.T.A., Roelofs, J.G.M., Lamers, L.P.M., 2008. Sediment $\mathrm{Fe}: \mathrm{PO}_{4}$ ratio as a diagnostic and prognostic tool for the restoration of macro-phyte biodiversity in fen waters. Freshw. Biol. 53, 2101-2116. http:// dx.doi.org/10.1111/j.1365-2427.2008.02038.x.

Gibbs, R.J., 1970. Mechanisms controlling world water chemistry. Science 170 , 1088-1090.

Giles, N., 1994. Tufted duck (Aythya fuligula) habitat use and brood survival increases after fish removal from gravel pit lakes. Hydrobiologia 279 (280), 387-392. http://dx.doi. org/10.1007/BF00027870.

Gibson, J.J., Edwards, T.W.D., Bursey, G.G., Prowse, T.D., 1993. Estimating evaporation using stable isotopes: quantitative results and sensitivity analysis for two catchments in Northern Canada. Paper presented at the 9th Northern Res. Basin Symposium Workshop (Whitehorse/DawsodInuvik, Canada - August 1992). Nordic Hydrology 24, 79-94.

Gibson, J.J., Birks, S.J., Edwards, T.W.D., 2008. Global prediction of $\delta \mathrm{A}$ and $\delta^{2} \mathrm{H}-\delta^{18} \mathrm{O}$ evaporation slopes for lakes and soil water accounting for seasonality. Global Biogeochem.

Cycles 22. http://dx.doi.org/10.1029/2007GB002997 GB2031.

Giorgi, F., Lionello, P., 2008. Climate change projections for the Mediterranean region. Glob. Planet. Chang. 63, 90-104. http://dx.doi.org/10.1016/j.gloplacha.2007.09.005.

Giovanoli, R., Schnoor, J.L., Sigg, L., Stumm, W., Zobrist, J., 1988. Chemical weathering of crystalline rocks in the catchment area of acidic Ticino lakes, Switzerland. Clay Clay Miner. 36 (6), 521-529.

Gonneea, M.E., Morris, P.J., Dulaiova, H., Charette, M.A., 2008. New perspectives on radium behavior within a subterranean estuary. Marine Chemistry 109, 250-267.

Green, T.R., Taniguchi, M., Kooi, H., Gurdak, J.J., Allen, D.M., Hiscock, K.M., Treidel, H., Aureli, A., 2011. Beneath the surface of global change: impacts of climate change on groundwa-ter. J. Hydrol. 405, 532-560. http://dx.doi.org/10.1016/j.jhydrol.2011.05.002.

Gudasz, C., Bastviken, D., Steger, K., Premke, K., Sobek, S., Tranvik, L.J., 2010. Temperaturecontrolled organic carbon mineralization in lake sediments. Nature 466, 478-481. http://dx.doi.org/10.1038/nature09186.

Halder, J., Decrouy, L., Vennemann, T.W., 2013. Mixing of Rhône River water in Lake Geneva (Switzerland-France) inferred from stable hydrogen and oxygen isotope pro-files. J.

Hydrol. 477, 152-164. http://dx.doi.org/10.1016/j.jhydrol.2012.11.026. Hamilton-Taylor, J. Willis, M., 1990. A quantitative assessment of the sources and general dynamics of trace metals in a soft-water lake. Limnology and Oceanography 35 (4), 840-851.

Hanson, P.C., Pace, M.L., Carpenter, S.R., Cole, J.J., Stanley, E.H., 2015. Integrating landscape carbon cycling: research needs for resolving organic carbon budgets of lakes. Ecosystems 18 (3), 363-375. http://dx.doi.org/10.1007/s10021-014-9826-9.

Helmer, C., Labroue, L., 1993. Denitrification in gravel-pit lakes. Hydrobiologia 251, 35-44. http://dx.doi.org/10.1007/BF00000126.

Henderson, A.K., Shuman, B.N., 2010. Differing controls on river- and lake-water hydrogen and oxygen isotopic values in the western United States. Hydrol. Process. 24 (26), 3894-3906. http://dx.doi.org/10.1002/hyp.7824

Herzsprung P. Schultze, M., Hupfer, M., Boehrer, B., Von Tümpling Jr., W., Duffek, A., Van der Veen, A., Friese, K., 2010. Flood effects on phosphorus immobilization in a river 
water filled pit lake-case study Lake Goitsche (Germany). Limnologica 40, 182-190. http://dx.doi.org/10.1016/j.limno.2009.11.007.

Hessen, D.O., Andersen, T., Larsen, S., Skjelkvåle, B.L., de Wit, H.A., 2009. Nitrogen deposition, catchment productivity, and climate as determinants of lake stoichiometry. Limnol. Oceanogr. 54 (6-2), 2520-2528. http://dx.doi.org/10.4319/lo.2009.54.6 part_2.2520.

Hindak, F., Hindakova, A., 2003. A. Diversity of cyanobacteria and algae of urban gravel pit lakes in Bratislava, Slovakia: a survey. Hydrobiologia 506-509, 155-162. http://dx. doi.org/10.1023/B:HYDR.0000008631.82041.c7.

Hiscock, K.M., Grischek, T., 2002. Attenuation of groundwater pollution by bank filtration. J. Hydrol. 266 (3-4), 139-144. http://dx.doi.org/10.1016/S0022-1694(02)00158-0. Hoffmann, A., Gunkel, G., 2011. Bank filtration in the sandy littoral zone of Lake Tegel (Berlin): structure and dynamics of the biological active filter zone and clogging processes. Limnologica 41 (1), 10-19. http://dx.doi.org/10.1016/j.limno.2009.12.003.

Iastour, 2014. http://www.iastour.com/Sport/Rowing-Training-Camps/Standiana.htm (consulted on 17/01/2014)

IBB, 2010. Notes to re-design deep small lakes. In Dutch: Implementatieteam Besluit Bodemkwaliteit. 2010. Handreiking Voor Het Herinrichten Van Diepe Plassen ILEC 2014 World Lake Database 2014. International Lake Environment Committee Foun-dation (http://wldb.ilec.or.jp consulted on 07/04/2014).

Iglesias-Rodriguez, M.D., Halloran, P.R., Rickaby, R.E.M., Hall, I.R., Colmenero-Hidalgo

E., Gittins, J.R., Green, D.R.H., Tyrrell, T., Gibbs, S.J., von Dassow, P., Rehm, E., Armbrust, E.V., Boessenkool, K.P., 2008. Phytoplankton calcification in a high- $\mathrm{CO}_{2}$ world. Science 320, 336-340. http://dx.doi.org/10.1126/science.1154122.

ILEC World Lake database, 2014. International Lake Environment Committee Foundation. http://wldb.ilec.or.jp consulted on 07/04/2014

Imboden, D.M. 2004. The motion of lake waters. In: The Lakes Handbook. O'sullivan, P.E. and Reynolds, C.S. (Eds) p. 115-153. DOI: http://dx.doi.org/10.1002/9780470999271.ch6

Imboden, D.M., Wuest, A., 1995. Mixing mechanisms in lakes. In: Lerman, A., Imboden, D.M., Gat, J.R. (Eds.), Physics and Chemistry of Lakes. Springer-Verlag, Berlin, pp. 83-138 (ISBN 0-632-D4797-6).

Immers, A.K., Bakker, E.S., Van Donk, E., Ter Heerdt, G.N.J., Geurts, J.J.M., Declerck, S.A.J. 2015. Fighting internal phosphorus loading: an evaluation of the large scale applica-tion of gradual Fe-addition to a shallow peat lake. Ecol. Eng. 83, 78-89. http://dx.doi. org/10.1016/j.ecoleng.2015.05.034.

IPCC, 2013. Climate change 2013: the physical science basis. Contribution of Working Group I to the Fifth Assessment Report of the Intergovernmental Panel on Climate Change [Stocker, T.F., D. Qin, G.-K. Plattner, M. Tignor, S.K. Allen, J. Boschung, A Nauels, Y. Xia, V. Bex and P.M. Midgley (eds.)]. Cambridge University Press, Cambridge, United Kingdom and New York, NY, USA, (1535 pp.).

Jensen, H.S., Andersen, F.O., 1992. Importance of temperature, nitrate, and pH for phosphate release from aerobic sediments of four shallow, eutrophic lakes. Limnol.

Oceanogr. 37 (3), 577-589. http://dx.doi.org/10.4319/lo.1992.37.3.0577.

Jeppesen, E., Jensen, J.P.Søndergaard M., Lauridsen, T., Pedersen, L.J., 1997. Top-down control in freshwater lakes: the role of nutrient state, submerged macrophytes and water depth. Shallow Lakes 151-164.

Jeppesen, E., Kronvang, B., Meerhoff, M., Sondergaard, M., Hansen, K.M., Andersen, H.E. Lauridsen, T.L., Beklioglu, M., Ozen, A., Olesen, J.E., 2009. Climate change effects on runoff, catchment phosphorus loading and lake ecological state, and potential adaptations. J. Environ. Qual. 38, 1930-1941. http://dx.doi.org/10.2134/jeq2008.0113.

Jeppesen, E., Søndergaard, M., et al., 2012. Biomanipulation as a restoration tool to combat eutrophication: recent advances and future challenges. Adv. Ecol. Res. 47, 411-487. http://dx.doi.org/10.1016/B978-0-12-398315-2.00006-5.

Jeppesen, E., Meerhoff, M., Davidson, T.A., Trolle, D., Søndergaard, M., Lauridsen, T.L., Beklioglu, M., Brucet, S., Volta, P., González-Bergonzoni, I., Nielsen, A., 2014 Climate change impacts on lakes: an integrated ecological perspective based on a multi-facet-ed approach, with special focus on shallow lakes. J. Limnol. 73 (s1), 88111. http://dx. doi.org/10.4081/jlimnol.2014.844

Jeppesen, E., Brucet, S., Naselli-Flores, L., Papastergiadou, E., Stefanidis, K., No ${ }^{g e s, ~ T . ~}$ No ges, P., Attayde, J.L., Zohary, T., Coppens, J., Bucak, T., Fernandes Menezes, R. Sousa Freitas, F.R., Kernan, M., Søndergaard, M., Bekliog`lu, M., 2015. Ecological impacts of global warming and water abstraction on lakes and reservoirs due to changes in water level and related changes in salinity. Hydrobiologia 750, 201-227. http://dx. doi.org/10.1007/s10750-014-2169-X.

Jeziorski, A., Yan, N.D., Paterson, A.M., DeSellas, A.M., Turner, M.A., Jeffries, D.S., Keller, B. Weeber, R.C., McNicol, D.K., Palmer, M.E., Mclver, K., Arseneau, K., Ginn, B.K. Cumming, B.F., P., S.J., 2008. The widespread threat of calcium decline in fresh waters. Science 322, 1374. http://dx.doi.org/10.1126/science.1164949.

Jones, M.D., Cuthbert, M.O., Leng, M.J., McGowan, S., Mariethoz, G., Arrowsmith, C., Sloane, H.J., Humphrey, K.K., Cross, I., 2016. Comparisons of observed and modelled lake $\delta^{18} \mathrm{O}$ vari-

ability. Quat. Sci. Rev. 131, 329-340. http://dx.doi.org/10.1016/j.quascirev.2015.09.012. Katz,

A., Nishri, A., 2013. Calcium, magnesium and strontium cycling in stratified, hardwater lakes: Lake Kinneret (Sea of Galilee), Israel. Geochimica et Cosmochimica Acta 105, 372-394. http://dx.doi.org/10.1016/j.gca.2012.11.045.

Kauffeldt, A., Wetterhall, F., Pappenberger, F., Salamon, P., Thielen, J., 2016. Technical review of large-scale hydrological models for implementation in operational flood forecasting schemes on continental level. 2016. Environ. Model. Softw. 75, 68-76. http:// dx.doi.org/10.1016/j.envsoft.2015.09.009.

Kelts, K., Hsu, K.J., 1978. Freshwater carbonate sedimentation. In: Lerman, A. (Ed.), Lakes-Chemistry, Geology, Physics. Springer- Verlag, New York

Kjoller, C., Postma, D., Larsen, F., 2004. Groundwater acidification and the mobilization of trace metals in a sandy aquifer. Environ. Sci. Technol. 38 (10), 2829-2835. http://dx.

doi.org/10.1021/es030133v.

KNMI 2014. KNMI'14: climate change scenarios for the 21st century. A Netherlands Perspective. (Ed) Vanden Hurk, B. et al, (Report WR2014-01,KNMI,De Bilt, The Netherlands.www.climatescenarios.n)
Kondolf, G.M., 1997. Hungry water: effects of dams and gravel mining on river channels. Environmental Management Vol. 21, 533-551.

Kopacek, J., Hejzlar, J., Vrba, J., Stuchlı'k, E., 2011. Phosphorus loading of mountain lakes: terrestrial export and atmospheric deposition. Limnol. Oceanogr. 56 (4),

1343-1354. http://dx.doi.org/10.4319/lo.2011.56.4.1343.

Kortelainen, P., Downing, J.A., Middelburg, J.J., Melack, J., 2007. Plumbing the global carbon cycle: integrating inland waters into the terrestrial carbon budget. Ecosystems 10, 171-184. http://dx.doi.org/10.1007/s10021-006-9013-8.

Kubicki, A., Manso, F., Diesing, M., 2007. Morphological evolution of gravel and sand extraction pits, Tromper Wiek, Baltic sea original research article. Estuar. Coast. Shelf Sci. 71 (3-4), 647-656. http://dx.doi.org/10.1016/j.ecss.2006.09.011.

Lambert-Servien, E., Clemenceau, G., Gabory, O., Douillard, E., Haury, J., 2006. Stoneworts (Characeae) and associated macrophyte species as indicators of water quality and human activities in the Pays-de-la-Loire region, France. Hydrobiologia 570, 107-115.

Lamers, L.P.M., Falla, S.J., Samborska, E.M., Van Dulken, I.A.R., Van Hengstum, G., Roelofs, J.G.M., 2002. Factors controlling the extent of eutrophication and toxicity in sulfate-polluted freshwater wetlands. Limnol. Oceanogr. 47, 585-593. http:// dx.doi.org/10. 4319/lo.2002.47.2.0585.

Lamers, L.P.M., Govers, L.L., Janssen, I.C.J.M., Geurts, J.J.M., Van der Welle, M.E.W., Van Katwijk, M.M., Van der Heide, T., Roelofs, J.G.M., Smolders, A.J.P., 2013. Sulfide as a soil phytotoxin-a review. Front Plant Sci. 4, 268. http://dx.doi.org/10.3389/fpls. 2013.00268

Lavergne, S., Mouquet, N., Thuiller, W., Ronce, O., 2010. Biodiversity and climate change: integrating evolutionary and ecological responses of species and communities. Annu. Rev. Ecol. Evol. Syst. 41, 321-350. http://dx.doi.org/10.1146/annurevecolsys-102209-144628.

LaZerte, B.D., Dillon, P.J., 1984. Relative importance of anthropogenic versus natural sources of acidity in lakes and streams of Central Ontario. Can. J. Fish. Aquat. Sci. 41

(11), 1664-1677. http://dx.doi.org/10.1139/f84-205.

Lemann, M.F., 2008. Waste Management. Peter Lang International Academic Publishers (ISBN-10: 3039115146 ISBN-13: 978-3039115143).

Lewis, W.M.Jr, 1980. Evidence for stable zooplankton community structure gradients maintained by predation. Pp. 625-634. In: Kerfoot, C. (Ed.), American Society of Lim-nology and Oceanography, Special Symposium \#3The Evolution and Ecology of Zoo-plankton Communities. The University Press of New England, Hanover.

Liu, Z, Dreybrodt W. Wang. $\mathrm{H}$, 2010. A new direction in effective accounting for the atmospheric $\mathrm{CO}_{2}$ budget: considering the combined action of carbonate dissolution, the global water cycle and photosynthetic uptake of DIC by aquatic organisms. Earth Sci. Rev. 99, 162-172. http://dx.doi.org/10.1016/j.earscirev.2010.03.001.

Löffler, H., 2003. The Origin of Lake Basins. In: O'Sullivan, P., Reynolds, C.S. (Eds.), The Lakes HandbookLakes, Limnology and Limnetic Ecology vol. 1. Wiley-Blackwell, p. 52 (ISBN: 978-0-632-04797-0 708 pp.).

Longinelli, A., Anglesio, E., Flora, O., Lacumin, P., Selmo, E., 2006. Isotopic composition of precipitation in northern Italy: reverse effect of anomalous climatic events. J. Hydrol. 329, 471-476. http://dx.doi.org/10.1016/j.jhydrol.2006.03.002. Maidment, D.R., 1992. Handbook of Hydrology. McGrawHill, Columbus.

Malcolm, J.R., Markham, M., Neilson, R.P., Garaci, M., 2002. Estimated migration rates under scenarios of global climate change. J. Biogeogr. 29 (7), 835-849.

Maltby, E., Barker, T. (Eds.), 2009. The Wetlands Handbook. Wiley-Blackwell (1058 pp.).

Manahan, S.E. (Ed.), 2013. Fundamentals of Environmental and Toxicological Chemistry: Sustainable Science. CRC Press (614 pp.).

Marcé, R., Obrador, B., Morguí, J.-A., Lluís Riera, J., López, P., Armengol, J., 2015. Carbonate weathering as a driver of $\mathrm{CO}_{2}$ supersaturation in lakes. Nat. Geosci. 8, 107-111. http://dx.doi.org/10.1038/ngeo2341.

Marques, E.D., Sella, S.M., de Mello, W.Z., Lacerda, L.D., Silva-Filho, E.V., 2008. Hydrogeochemistry of sand pit lakes at Sepetiba Basin, Rio de Janeiro southeastern Brazil. Water Air Soil Pollut. 189, 21-36. http://dx.doi.org/10.1007/ s11270-007-9550-6.

Masoner, J.R., Stannard, D.I., 2010. A comparison of methods for estimating open water evaporation in small wetlands. Wetlands 30 (3), 513-524. http://dx.doi.org/10.

1007/s13157-010-0041.

Masoner, et al., 2007. United States patent no: US 7,162,923 B1. Design for Adjustable Open Water Floating Evaporation Pan.

Masoner, J.R., Stannard, D.I., Christenson, S.C., 2008. Differences in evaporation between a floating pan and class a pan on land. J. Am. Water Resour. Assoc. 44 (3), 552-561.

http://dx.doi.org/10.1111/j.1752-1688.2008.00181.x

Mas-Plaa, J., Montaner, J., Sola, J., 1999. Groundwater resources and quality variations caused by gravel mining in coastal streams. J. Hydrol. 216, 197-213. http://dx.doi. org/10.1016/S0022-1694(99)00009-8.

Mayr, C., Lücke, A., Stichler, W., Trimborn, P., Ercolano, B., Oliva, G., Ohlendorf, C., Soto, J. Fey, M., Haberzettl, T., Janssen, S., Schäbitz, F., Schleser, G.H., Wille, M., Zolitschka, B. 2007. Precipitation origin and evaporation of lakes in semi-arid Patagonia (Argentina) inferred from stable isotopes $\left(\delta^{18} \mathrm{O}, \delta^{2} \mathrm{H}\right)$. Journal of Hydrology 34, 53-63.

McDonald, C.P., Rover, J.A., Stets, E.G., Striegl, R.G., 2012. The regional abundance and size distribution of lakes and reservoirs in the United States and implications for estimates of global lake extent. Limnol. Oceanogr. 57, 597-606. http:// dx.doi.org/10.4319/lo. 2012.57.2.0597.

McDonald, C.P., Stets, E.G., Striegl, R.G. Butman, D. 2013. Inorganic carbon loading as a primary driver of dissolved carbon dioxide concentrations in the lakes and reservoirs of the contiguous United States. Glob. Biogeochem. Cycles 27, 285-295. http://dx.doi. org/10.1002/gbc.20032.

Meybeck, M. 1995. Global Distribution of Lakes. In: Lerman, A, Imboden, D. Gat, J. (Eds.) Physics and Chemistry of Lakes, second ed. Springer, Berlin, pp. 1-35.

Meybeck, M., 2003. Global analysis of river systems: from earth system controls to Anthropocene syndromes. Philos. Trans. R. Soc. Lond. Ser. B Biol. Sci. 358, 1935-1955. http://dx.doi.org/10.1098/rstb.2003.1379. 
Migon, C., Sandroni, V., 1999. Phosphorus in rainwater: partitioning inputs and impact on the surface coastal ocean. Limnol. Oceanogr. 44 (41), 1160-1165. http://dx.doi.org/ 10.4319/lo.1999.44.4.1160.

Miller, G.C., Lyons, W.B., Davis, A., 1996. Understanding the water quality of pit lakes. Environ. Sci. Technol. 30 (3), 118A-123A. http://dx.doi.org/10.1021/es9621354.

Minear, J.T., Kondolf, G.M., 2009. Estimating reservoir sedimentation rates at large spatia and temporal scales: a case study of California. Water Resour. Res. 45, W12502.

http://dx.doi.org/10.1029/2007WR006703.

Mironov, D., Rontu, L., Kourzeneve, E., Terzhevik, A., 2010. Towards improved representation of lakes in numerical weather prediction and climate models: introduction to the special issue of boreal environment research. Boreal Environ. Res. 15, 97-99 (ISSN 1239-6095).

Mohamed, Y.A., Bastiaanssen, W.G.M., Savenije, H.H.G., van den Hurk, B.J.J.M., Finlayson, M., 2012. Wetland versus open water evaporation: a theoretical analysis and litera-ture review. Phys. Chem. Earth 47-48, 114-121. http://dx.doi.org/10.1016/ j.pce. 2011.08.005.

Mollema, P.N., 2016. Water and Chemical Budgets of Gravel Pit Lakes. Case Studies of Fluvial Gravel Pit Lakes along the Meuse River (the Netherlands) and Coastal Gravel Pit Lakes along the Adriatic Sea (Ravenna, Italy). (PhD thesis) Technical University Delft (204 pp. ISBN 978-94-6233-214-0).

Mollema, P., Antonellini, M., Gabbianelli, G., Laghi, M., Marconi, V., Minchio, A., 2012. Climate and water budget change of a Mediterranean coastal watershed, Ravenna, Italy.

Environ. Earth Sci. 65 (1), 257-276. http://dx.doi.org/10.1007/s12665-011-1088-7. Mollema, P.N., Antonellini, M., Gabbianelli, G., Laghi, M., June 2010. The Influence of Surface Water Evaporation on Salt Water Intrusion in Ravenna, Italy. Implications for Climate ChangeProceedings of the Salt Water Intrusion Meeting, Sao Miguel, Azores.

Mollema, P.N., Antonellini, M., Dinelli, E., Gabbianelli, G., Greggio, N., Stuyfzand, P. 2013a. Hydrochemical and Physical Processes Influencing Salinization and Freshening in Mediterranean Low-Lying Coastal Environments on-Line by Applied Geochemistry Vol. 34 pp. 207-221. http://dx.doi.org/10.1016/j.apgeochem.2013.03.017.

Mollema, P.N., Antonellini, M., Gabbianelli, G., Galloni, E., 2013b. Water budget management of a coastal pine forest in a Mediterranean catchment (Marina Romea, Ravenna

Italy). Environ. Earth Sci. http://dx.doi.org/10.1007/s12665-012-1862-1.

Mollema, P.N., Stuyfzand, P.J., Juhasz-Holterman, M.H.A., Van Diepenbeek, P.M.J.A Antonellini, M., 2015a. Metal accumulation in an artificially recharged gravel pit lake used for drinking water supply. J. Geochem. Explor. 150, 35-51. http://dx.doi. org/10.1016/j.gexplo.2014.12.004.

Mollema, P.N., Antonellini, M., Dinelli, E., Greggio, N., Stuyfzand, P.J., 2015b. The influence of flow-through saline gravel pit lakes on the hydrologic budget and hydrochemistry of a Mediterranean drainage basin. Limnol. Oceanogr. 60, 20092025. http://dx.doi. org/10.1002/lno.10147.

Moore, W.S., Shaw, T.J., 2008. Fluxes and behavior of radium isotopes, barium, and uranium in seven Southeastern US rivers and estuaries. Mar. Chem. 108, 236-254. http:// dx.doi.org/10.1016/j.marchem.2007.03.004.

Muellegger, C., Weilhartner, A., Battin, T.J., Hofmann, T., 2013. Positive and negative impacts of five Austrian gravel pit lakes on groundwater quality. Sci. Total Environ. 443

14-23. http://dx.doi.org/10.1016/j.scitotenv.2012.10.097.

Naeher, S., Gillic, A., North, R.P., Hamann, Schubert, C.J., 2013. Tracing bottom water oxy genation with sedimentary Mn/Fe ratios in Lake Zurich, Switzerland. Chem. Geol. 352, 125-133. http://dx.doi.org/10.1016/j.chemgeo.2013.06.006.

Neilson, L.F., 2013. Gravel Pits Were Scene of Multiple Deaths by Drowning Wilmington Town Crier Posted: Sunday, August 4, 2013 9:10 Am.

Nilles, M.A., Conley, B.E., 2001. Changes in the chemistry of precipitation in the United States, 1981-1998. Water Air Soil Pollut. 130, 409-414. http://dx.doi.org/10.1023/A:

1013889302895.

Nõges, P., Cremona, F., Laas, A., Martma, T., Rõõm, E.-A., Toming, K., Viik, M., Vilbaste, S. Nõges, T., 2016. Role of a productive lake in carbon sequestration within a calcareous catchment. Sci. Total Environ. 550, 225-230.

Novo, A.V., Bayon, J.R., Castro-Fresno, D., Rodriguez-Hernandez, J., 2010. Review of seasonal heat storage in large basins: water tanks and gravel-water pits. Appl. Energy

87, 390-397. http://dx.doi.org/10.1016/j.apenergy.2009.06.033.

Nyquist, J.E., Heaney, M.J., Toran, L., 2009. Characterizing lakebed seepage and geologic heterogeneity using resistivity imaging and temperature measurements. Near Surf. Geophys. 7, 487-498. http://dx.doi.org/10.3997/1873-0604.2009022.

Olsen, S., Jeppesen, E., Moss, B., Özkan, K., Beklioğlu, M., Feuchtmayr, H., González Sagrario, M., Wei, L., Larsen, S., Søndergaard, M., 2015. Factors influencing nitrogen processing in lakes: an experimental approach. Freshw. Biol. 60, 646-662. http:// dx. doi.org/10.1111/fwb.12511.

Oude Essink, G.H.P., van Baaren, E.S., de Louw, P.G.B., 2010. Effects of climate change on coastal groundwater systems: a modeling study in the Netherlands. Water Resour.

Res. 46, W00F04. http://dx.doi.org/10.1029/2009WR008719.

Ozen, A., Karapınar, B., Kucuk, I., Jeppesen, E., Beklioglu, M., 2010. Drought-induced changes in nutrient concentrations and retention in two shallow Mediterranean lakes subjected to different degrees of management. Hydrobiologia 646, 61-72. http://dx.doi.org/10.1007/s10750-010-0179-X.

Padisák, J., 2004. Phytoplankton. In: O'Sullivan, P.E., Reynolds, C.S. (Eds.), The Lakes Handbook Volume 1 Limnology and Limnetic Ecology. Blackwell Publishing, pp. 251-308.

Padisák, J., Borics, G., Fehér, G., Grigorszky, I., Oldal, I., et al., 2003. Dominant species, functional assemblages and frequency of equilibrium phases in late summer phytoplankton assemblages in Hungarian small shallow lakes. Hydrobiologia 502, 157-168.

Paerl, H.W., Paul, V.J., 2012. Climate change: links to global expansion of harmful cyanobacteria. Water Res. 46, 1349-1363.

Peckenham, J., Thornton, T., Whalen, B., 2009. Sand and gravel mining: effects on ground water resources in Hancock county, Maine, USA. Environ. Geol. 56, 1103. http://dx.

doi.org/10.1007/s00254-008-1210-7

Penman, H.L., 1948. Natural evaporation from open water bare soil and grass. Proc. R. Soc. Lond. A193, 120-146.
Pickens, J.F., Cherry, J.A., Grisak, G.E., Merrit, W.F., Risto, B.A., 1978. A multi-level device for groundwater sampling and piezometer monitoring. Ground Water 16 (5), 322-327.

Pôças, I., Cunha, M., Pereira, L.S., Allen, R.G., 2013. Using remote sensing energy balance and evapotranspiration to characterize montane landscape vegetation with focus on grass and pasture lands. International Journal of Applied Earth Observation and Geoinformation 21, 159-172.

Pokorný J. and Květ, J. 2004. Aquatic plants and lake ecosystems In: The Lakes Handbook O'sullivan, PE and Reynolds, CS (Eds) p. 310-340. (ISBN 978-0-632-04797-0)

Ponton, D.E., Hare, L., 2009. Assessment of nickel contamination in lakes using the phantom midge Chaoborus as a biomonitor. Environ. Sci. Technol. 43, 6529-6534. http://dx.doi.org/10.1016/j.aquatox.2009.09.011.

Psenner, R., Schmidt, R., 1992. Climate-driven pH control of remote alpine lakes and effects of acid deposition. Nature 356, 781-783. http://dx.doi.org/10.1038/356781a0

Raymond, P.A., Hartmann, J., Guth, P., et al., 2015. Global carbon dioxide emissions from inland waters. Nature 503, 355-359. http://dx.doi.org/10.1038/nature12760.

Reynolds, C.S., 2004. Organisation and energetic partitioning of limnetic communities. In: O'Sullivanand, P.E., Reynolds, C.S. (Eds.), The Lakes HandbookLimnology and Limnetic Ecology vol. 1. Blackwell Publishing, pp. 230-249.

RIVM, 2011. Dutch National Monitoring network air quality. http://www.lml.rivm.nl/ data/gevalideerd/ (data for station Vredepeel 2011 downloaded 10/01/2014).

RIWA, 2013. http://www.riwa-maas.org/nc/en/quality-measurements.html consulted $18 / 06 / 2013$.

Rojo, C., Alvarez Cobelas, M., 1994. Population dynamics of Limnothrix redekei, Oscillatoria lanceaeformis, Planktothrix agardhii and Pseudanabaena limnetica (cyanobacteria) in a

shallow hypertrophic lake (Spain). Hydrobiologia 275 (1), 165-171.

Rosenzweig C. Casassa, G. Karoly, D. Imeson, A. Liu, C. Menzel, A Rawlins, S. Root, T.L. Seguin, B., Tryjanowski, P., Hanson, C.E., 2007. Assessment of observed changes and responses in natural and managed systems. In: Parry, M.L., Canziani, O.F., Palutikof, J.P., van der Linden, P.J. (Eds.), Climate Change 2007: Impacts, Adaptation and Vulnerability. Contribution of Working Group II to the Fourth Assessment Report of the Intergovernmental Panel on Climate Change. Cambridge University Press, pp. 79-131.

Sahoo, G.B., Forrest, A.L., Schladow, S.G., Reuter, J.E., Coats, R., Dettinger, M., 2015. Climate change impacts on lake thermal dynamics and ecosystem vulnerabilities. Limnol.

Oceanogr. http://dx.doi.org/10.1002/lno.10228

Santoul, F., Gaujard, A., Angélibert, S., Mastrorillo, S., Céréghino, R., 2009. Gravel pits support waterbird diversity in an urban landscape. Hydrobiologia 634, 107-114. http://dx.doi.org/10.1007/s10750-009-9886-6.

Sayer, C.D., Roberts, N., 2001. Establishing realistic restoration targets for nutrientenriched shallow lakes: linking diatom ecology and palaeoecology at the

Attenborough Ponds, U.K. Hydrobiologia 448, 117-142.

Sayer, C.D., Davidson, T.A., Jones, I.J., Langdon, P.G., 2010a. Combining contemporary ecology and palaeolimnology to understand shallow lake ecosystem change. Freshw. Biol. 55, 487-499.

Sayer, C.D., Davidson, T.A., Jones, J.I., 2010b. Seasonal dynamics of macrophytes and phytoplankton in shallow lakes: a eutrophication-driven pathway from plants to plank-ton. Freshw. Biol. 55, 500-513. http://dx.doi.org/10.1111/j.1365-2427.2009.02365.x.

Scheffer, M., 2001. Climatic warming causes regime shifts in lake food webs. Limnol. Oceanogr. 46 (7), 1780-1783. http://dx.doi.org/10.4319/lo.2001.46.7.1780.

Schilder, J., Bastviken, D., van Hardenbroek, M., Leuenberger, M., Rinta, P., Stötter, T., Heiri, O., 2015. The stable carbon isotopic composition of Daphnia ephippia in small, temperate lakes reflects in-lake methane availability. Limnol. Oceanogr. 60, 1064-1075. http://dx.doi.org/10.1002/lno.10079.

Schlieker, M., Schüring, J., Hencke, J., Schulz, H.D., 2001. The influence of redox processes on trace element mobility in a sandy aquifer-an experimental approach. J. Geochem. Explor. 73 (3), 167-179. http://dx.doi.org/10.1016/S0375-6742(01)00195-9.

Schmidt, M., Hunziker, S., Wüest, A., 2014. Lake surface temperatures in a changing climate: a global sensitivity analysis. Clim. Chang. http://dx.doi.org/10.1007/ s10584-014-1087-2.

Schneider, P., Hook, S.J., 2010. Space observations of inland water bodies show rapid surface warming since 1985. Geophys. Res. Lett. 37, L22405. http://dx.doi.org/10.1029/ 2010GL045059.

Seekell, D.A.-A., Pace, M.L., Tranvik, L.J., Verpoorter, C., 2013. A fractalbased approach to lake size-distributions. Geophys. Res. Lett. 40, 517-521. http:// dx.doi.org/10.1002/grl.50139.

Seneviratne, S.I., Corti, T., Davin, E.L., Hirschi, M., Jaeger, E.B., Lehner, I., Orlowsky, B., Teuling, A.J., 2010. Investigating soil moisture-climate interactions in a changing cli-mate: a review. Earth Sci. Rev. 99, 125-161. http://dx.doi.org/10.1016/ j.earscirev. 2010.02.004

Shevenell, L.A., Connors, K.A., Henry, C.D., 1999. Controls on pit lake water quality at sixteen open-pit mines in Nevada. Appl. Geochem. 14, 669-687. http://dx.doi.org/10.

1016/S0883-2927(98)00091-2.

Shugar, D.H., Clague, J.J., 2011. The sedimentology and geomorphology of rock avalanche deposits on glaciers. Sedimentology 58, 1762-1783. http://dx.doi.org/10.1111/j. 1365-3091.2011.01238.x

Sickman, J.O., Melack, J.M., Clow, D.W., 2003. Evidence for nutrient enrichment of high-elevation lakes in the Sierra Nevada,California. Limnol. Oceanogr. 48 (5), 1885-1892. Sigg, L., Sturm, M., Kistler, D., 1987. Vertical transport of heavy metals by settling particles in Lake Zurich. Limnol. Oceanogr. 32, 112-130. http://dx.doi.org/10.4319/lo.1987.32. 1.0112 .

Skrzypek, G., Mydłowski, A., Dogramaci, S., Hedley, P., Gibson, J.J., Grierson, P.F., 2015.

Es- timation of evaporative loss based on the stable isotope composition of water using hydrocalculator. J. Hydrol. 523, 781-789. http://dx.doi.org/10.1016/ j.jhydrol.2015. 02.010

Smedley, P.L., Kinniburgh, D.G., 2002. A review of the source, behaviour and distribution of arsenic in natural waters. Appl. Geochem. 17, 517-568. http:// dx.doi.org/10.1016/S0883-2927(02)00018-5. 
Smith, M., 1992. CROPWAT-a computer program for irrigation planning and management. Irrigation and Drainage Paper 46. FAO, Rome (Program available from http:// www.fao.org/nr/water/infores_databases_cropwat.html).

Smith, V.H., Schindler, D.W., 2009. Eutrophication science: where do we go from here? Trends Ecol. Evol. 24, 201-207. http://dx.doi.org/10.1016/j.tree.2008.11.009.

Smolders, A.J.P., Roelofs, J.G.M., 1996. The roles of internal iron hydroxide precipitation, sulphide toxicity and oxidizing ability in the survival of strtiotes aloides roots at dif-

ferent iron concentrations in sediment pore water. New Phytol. 133, 253-260. Smolders, A.J.P., Lamers, L.P.M., Lucassen, E.C.H.E.T., Van der Velde, G., Roelofs, J.G.M., 2006. Internal eutrophication: how it works and what to do about it-a review. Chem. Ecol. 22, 93-111. http://dx.doi.org/10.1080/02757540600579730.

Sommaruga-WÖgrath, S., Koinig, K.A., Schmidt, R., Sommaruga, R., Tessadri, R., Psenner, R., 2013. Temperature effects on the acidity of remote alpine lakes. Nature 387, 64-67. http://dx.doi.org/10.1038/387064a0.

Sommer, U., Gliwicz, Z.M., Lampert, W., Duncan, A., 1986. The PEG-model of seasonal succession of planktonic events in fresh waters. Arch. Hydrobiol. 106, 433-471.

Søndergaard, M., Jeppesen, E., Mortensen, E., Dall, E., Kristensen, P., Sortkjær, O., 1990. Phytoplankton biomass reduction after planktivorous fish reduction in a shallow, eu-trophic lake: a combined effect of reduced internal P-loading and increased zoo-plankton grazing. Hydrobiologia 200/201, 229-240.

Søndergaard, M., Jensen, J.P., Jeppesen, E., 2003. Role of sediment and internal loading of phosphorus in shallow lakes. Hydrobiologia 506/509, 135-145.

Søndergaard, M., Jensen, J.P., Jeppesen, E., 2005. Seasonal response of nutrients to reduced phosphorus loading in 12 Danish lakes. Freshw. Biol. 50, 1605-1615. http://dx.doi.

org/10.1111/j.1365-2427.2005.01412.x.

Stephenson, D.A., Fleming, A.H., Mickelson, D.M., 1988. Glacial deposits. The Geology of North AmericaHydrogeology vol. O-2. The Geological Society of America.

Stets, E.G., Kelly, V.J., Crawford, C.G., 2014. Long-Term Trends in Alkalinity in Large Rivers of the Conterminous US in Relation to Acidification, Agriculture, and Hydrologic Mod-ification Science of the Total Environment Vols. 488-489 pp. 280-289. http:// dx.doi. org/10.1016/j.scitotenv.2014.04.054

Straile, D., 2000. Meteorological forcing of plankton dynamics in a large and deep continental European lake. Oecologia 122, 44-50.

Stubbs, B.J., Smith, J.V., 1997. Weathered bedrock is found to be source of sand and aggregate in north-eastern New South Wales. Aust. Environ. Geol. 32 (1), 64-70. http://dx.

doi.org/10.1007/s002540050194.

Stumm, W. 2004. Chemical processes regulating the composition of lake waters. In: The Lakes Handbook. O'Sullivan, PE and Reynolds, CS (Eds). p. 79-106. (ISBN: 978-0-632-04797-0 708 pages) Wiley-Blackwell

Stuyfzand, P.J., 1999. Patterns in groundwater chemistry resulting from groundwater flow. Hydrogeol. J. 7, 15-27. http://dx.doi.org/10.1007/s100400050177.

Taniguchi, M., Burnett, W.C., Dulaiova, H., Kontar, E.A., Povine, P.P., Moore, W.S., 2006. Submarine groundwater discharge measured by seepage meters in sicilian coastal waters. Cont. Shelf Res. 26 (7), 835-842. http://dx.doi.org/10.1016/j.csr.2005.12.002.

Tessier, A., Rapin, F., Carignan, R., 1985. Trace metals in oxic lake sediments: possible adsorption onto iron oxyhydroxides. Geochim. Cosmochim. Acta 49 (1), 183-194. Tranvik, L.J., et al., 2009. Lakes and reservoirs as regulators of carbon cycling and climate. Limnol. Oceanogr. 54, 2298-2314. http://dx.doi.org/10.4319/lo.2009.54.6_part_2. 2298

Tremel, B., 1996. Determination of the trophic state by qualitative and quantitative phytoplankton analysis in two gravel pit lakes. Hydrobiologia 323 (2), 97-105.

Trolle, D., Nielsen, A., Rolighed, J., Thodsen, H., Andersen, H.E., Karlsson, I.B., Refsgaard, J.C. Olesen, J.E., Bolding, K., Kronvang, B., Søndergaard, M., Jeppesen, E., 2015. Projecting the future ecological state of lakes in Denmark in a 6 degree warming scenario. Clim. Res. 64, 55-72. http://dx.doi.org/10.3354/cr01278.

Turnadge, C., Smerdon, B.D., 2014. A review of methods for modelling environmenta tracers in groundwater: advantages of tracer concentration simulation. Rev. Artic J. Hydrol. 519, 3674-3689.

Turner, K.T., et al., 2016. A review of methods, data, and models to assess changes in the value of ecosystem services from land degradation and restoration. Ecol. Model. 319,

190-207. http://dx.doi.org/10.1016/j.ecolmodel.2015.07.017.

USGS, 2015a. Mineral Commodity Summaries 2015a: U.S. Geological Survey (196 pp. ISBN ISBN 978-1-4113-3877-7).

USGS, 2015b. http://minerals.usgs.gov/minerals/ (consulted 18/11/2015).

Van Balen, R.T., Busschers, F.S., 2010. Human presence in the central Netherlands during early MIS 6 ( 170-190 Ka): evidence from early Middle Palaeolithic artefacts in ice-

pushed Rhine-Meuse sediments Netherlands. Journal of Geosciences 89 (1), 77-83. Van Heerwaarden, C.C., Vilà-Guerau de Arellano, J., Teuling, A.J., 2010a. Land-atmosphere coupling explains the link between pan evaporation and actual evapotranspiration trends in a changing climate. Geophys. Res. Lett. 37, L21401. http://dx.doi.org/10. 1029/2010GL045374.

Van Heerwaarden, C.C., Vilà-Guerau de Arellano, J., Gounou, A., Guichard, F., Couvreux, F., $2010 \mathrm{~b}$. Understanding the daily cycle of evapotranspiration: a method to quantify the influence of forcings and feedbacks. J. Hydrometeorol. 11, 1405-1422. http:// dx.doi. org/10.1175/2010JHM1272.1.

Van Nes, E.H., Scheffer, M., Van den Berg, M.S., Coops, H., 2002. Aquatic macrophytes: restore, eradicate or is there a compromise? Aquat. Bot. 72, 387-403.

Vane, C.H., Kim, A.W., McGowan, S., Leng, M.J., Heaton, T.H.E., Kendrick, C.P., Coombs, P., Yang, H., Swann, G.E.A., 2010. Sedimentary records of sewage pollution using faecal markers in contrasting peri-urban shallow lakes. Sci. Total Environ. 409, 345-356.
Verpoorter, C., Kutser, T., Seekell, D.A., Tranvik, L.J., 2014. A global inventory of lakes based on high resolution satellite imagery. Geophys. Res. Lett. 41 (18), 6396-6402. http:// dx.doi.org/10.1002/2014GL060641.

Veselý, J., Majer, V., Kopáček, J., Norton, S.A., 2003. Increasing temperature decreases aluminum concentrations in Central European lakes recovering from acidification. Limnol. Oceanogr. 48 (6), 2346-2354. http://dx.doi.org/10.4319/lo.2003.48.6.2346. Vet,

R., et al., 2014. Addendum to: "a global assessment of precipitation chemistry and deposition of sulfur, nitrogen, sea salt, base cations, organic acids, acidity and $\mathrm{pH}$ and phosphorus". Atmos. Environ. 93, 101-116. http://dx.doi.org/10.1016/ j.atmosenv. 2014.02.017.

Vila-Costa, M., Pulido, C., Chappuis, E., Calviño, A., Casamayor, E.O., Gacia, E., 2016. Macrophyte landscape modulates lake ecosystem-level nitrogen losses through tightly coupled plant-microbe interactions. Limnol. Oceanogr. 61, 78-88. http:// dx.doi.org/ 10.1002/lno.10209.

Visser, A., Kroes, J., van Vliet, M.T.H., Blenkinsop, S., Fowler, H.J., Broers, H.P., 2012. Climate change impacts on the leaching of a heavy metal contamination in a small lowland catchment. J. Contam. Hydrol. 127, 47-64.

Wagner, C., Adrian, R., 2009. Cyanobacteria dominance: quantifying the effects of climate change. Limnol. Oceanogr. 54 (6-2), 2460-2468.

Walker, B., Steffen, W., 1997. An overview of the implications of global change for natural and managed terrestrial ecosystems. Conserv. Ecol. 1 (2), 2 (online). (Available from

the Internet. URL: http://www.consecol.org/vol1/iss2/art2/).

Walpersdorf, E., Neumann, T., Steuben, D., 2004. Efficiency of natural calcite precipitation compared to lake marl application used for water quality improvement in an eutro-phic lake. J. Appl. Geochem. 19, 1687-1698. http://dx.doi.org/10.1016/ j.apgeochem. 2004.04.007.

Wang, S., Mulligan, C.N., 2006. Effect of natural organic matter on arsenic release from soils and sediments into groundwater. 2006. Environ. Geochem. Health 28 (3),

197-214.

Ward, P.J., Renssen, H., Aerts, J.C.J.H., van Balen, R.T., Vandenberghe, J., 2008. Strong increases in flood frequency and discharge of the River Meuse over the late Holocene: impacts of long-term anthropogenic land use change and climate variability. Hydrol. Earth Syst. Sci. 12, 159-175 (www.hydrol-earth-syst-sci.net/12/159/2008/).

Waterpark, 2014. http://www.waterpark.org (consulted on 17/01/2014).

Weilhartner, A., Muellegger, C., Kainz, M., Mathieu, F., Hofmann, T., Battin, T.J., 2012.

Gravel pit lake ecosystems reduce nitrate and phosphate concentrations in the outflowing groundwater. Sci. Total Environ. 420, 222-228. http://dx.doi.org/10.1016/j.scitotenv. 2012.01.032.

Weiske, A., Schaller, J., Hegewald, T., Kranz, U., Feger, K.-H., Werner, I., Dudel, G., 2013. Changes in catchment conditions lead to enhanced remobilization of arsenic in water reservoir. Sci. Total Environ. 449, 63-70. http://dx.doi.org/10.1016/ j.scitotenv. 2013.01.041.

Weisse, T., 2004. Pelagic Microbes -Protozoa and the Microbial Food Web. In: O'Sullivan, P.E., Reynolds, C.S. (Eds.), The Lakes HandbookLimnology and Limnetic Ecology vol. 1. Blackwell Publishing.

Werner, A.D., Bakker, M., Post, V.E.A., Vandenbohede, A., Lu, C., Ataie-Ashtiani, B. Simmons, C.T., Barry, D.A., 2013. Seawater intrusion processes, investigation and management: recent advances and future challenges. Adv. Water Resour. 51, 326. http://dx.doi.org/10.1016/j.advwatres.2012.03.004.

Wetzel, R.G., Likens, G.E., 1991. Limnological Analysts. second ed. Springer (ISBN 978-14757-3250-4)

WHO, 2014. http://www.who.int/water_sanitation_health/bathing/en/ (consulted on 07/ 05/2014).

Wiik, E., Bennion, H., Sayer, C.D., Willby, N.J., 2013. Chemical and biological responses of Marl Lakes to eutrophication. Freshwat. Rev. 6 (2), 35-62. http://dx.doi.org/10. 1608/FRJ-6.2.630.

Williams, W.D., 2001. Anthropogenic salinisation of inland waters. Hydrobiologia 466 329-337. http://dx.doi.org/10.1023/A:1014598509028.

Winter, T.C., Rosenberry, D.O., Sturrock, A.M., 1995. Evaluation of 11 equations for determining evaporation for a small lake in the north Central United States. Water Resour.

Res. 31, 983-993, http://dx doi.org/10.1029/94WR02537.

Yeh, P.J.F., Swenson, S.C., Famiglietti, J.S., Rodell, M., 2006. Remote sensing of groundwater storage changes in Illinois using the gravity recovery and climate experiment (GRACE). Water Resour. Res. 42, W12203. http://dx.doi.org/10.1029/ 2006WR005374.

Younger, P.L., Robins, N.S., 2002. Challenges in the characterisation and prediction of the hydrogeology and geochemistry of mined ground. In: Younger, P.L., Robins, N.S (Eds.), Mine Water Hydrogeology and GeochemistryGeological Society, Special Pub-lications Vol. 198. Geological Society of London.

Yu, H., Tsuno, H., Hidaka, T., Jioa, C., 2010. Chemical and thermal stratification in lakes. Limnology 11, 251-257. http://dx.doi.org/10.1007/s10201-010-0310-8.

Zhao, Y., Marriott, S.B., 2013. Dispersion and remobilisation of heavy metals in the Rive Severn system, UK. Procedia Environ. Sci. 18, 167-173. http://dx.doi.org/10.1016/j. proenv.2013.04.022.

Zhao, T., Grenouillet, G., Pool, T., Tudesque, L., Cucherousset, J., 2015. Environmental determinants of fish community structure in gravel pitlakes. Ecol. Freshw. Fish http:// dx.doi.org/10.1111/eff.12222. 